IZA DP No. 6190

Institutional Reforms and Educational Attainment in Europe: A Long Run Perspective

Michela Braga

Daniele Checchi

Elena Meschi

December 2011 


\title{
Institutional Reforms and Educational Attainment in Europe: A Long Run Perspective
}

\author{
Michela Braga \\ University of Milan \\ Daniele Checchi \\ University of Milan \\ and IZA \\ Elena Meschi \\ Ca Foscari University of Venice
}

Discussion Paper No. 6190

December 2011

\author{
IZA \\ P.O. Box 7240 \\ 53072 Bonn \\ Germany \\ Phone: +49-228-3894-0 \\ Fax: +49-228-3894-180 \\ E-mail: iza@iza.org
}

Any opinions expressed here are those of the author(s) and not those of IZA. Research published in this series may include views on policy, but the institute itself takes no institutional policy positions.

The Institute for the Study of Labor (IZA) in Bonn is a local and virtual international research center and a place of communication between science, politics and business. IZA is an independent nonprofit organization supported by Deutsche Post Foundation. The center is associated with the University of Bonn and offers a stimulating research environment through its international network, workshops and conferences, data service, project support, research visits and doctoral program. IZA engages in (i) original and internationally competitive research in all fields of labor economics, (ii) development of policy concepts, and (iii) dissemination of research results and concepts to the interested public.

IZA Discussion Papers often represent preliminary work and are circulated to encourage discussion. Citation of such a paper should account for its provisional character. A revised version may be available directly from the author. 


\section{ABSTRACT}

\section{Institutional Reforms and Educational Attainment in Europe: A Long Run Perspective*}

In this paper we analyse the effects of changes in the institutional design of the educational system on school attainment. In particular, we test whether alternative reforms have increased the average educational attainment of the population and whether various deciles of the education distribution have been differentially affected. We constructed a dataset of relevant reforms occurred at the national level over the last century, and match individual information to the most likely set-up faced when individual educational choices were undertaken. Thus our identification strategy relies on temporal and geographical variations in the institutional arrangements, controlling for time/country fixed effects, as well as for confounding factors. We also explore who are the individual most likely affected by the reforms. We also group different reforms in order to ascertain the prevailing attitudes of policy makers, showing that reforms can belong to either "inclusive" or "selective" in their nature. Finally we correlate these attitudes to political coalitions prevailing in parliament, finding support to the idea that left wing parties support reforms that are inclusive in nature, while right wing parties prefer selective ones.

JEL Classification: $\quad 12$

Keywords: education, institutions, reform, family background

Corresponding author:

Daniele Checchi

Department of Economics

University of Milan

Via Conservatorio 7

20122 Milano

Italy

E-mail: daniele.checchi@unimi.it

\footnotetext{
* Preliminary version of a paper prepared for the $55^{\text {th }}$ Panel Meeting of Economic Policy, April 2012. This paper is part of a larger research project on "Growing INequalities' Impacts - GINI" financed by the European Commission under the $7^{\text {th }}$ Framework Programme (contract n. 244592). We thank research group participants to the Amsterdam meeting (23/10/10) for helpful comments on a draft version of the present paper. The collection of the dataset on educational institution has benefited from the precious help from Gosta Esping Andersen, Anna Baranowska, Arnaud Chevalier, Antonio Di Paolo, Marie Duru-Bellat, Robert Erikson, Randall K. Filer, Pedro Goulart, Mikolaj Herbst, Jan Herczynski, Daniel Horn, Dan Munich, Brian Nolan, Tuomas Pekkarinen, Kjell Salvanes, Maresa Sprietsma, Toth Istvan, Panos Tsakloglou, Anna Vignoles, Rudolf Winter-Ebmer, Krzysztof Zagórski. Insights and comments from Gabriele Ballarino, Massimiliano Bratti, Lorenzo Cappellari, Pedro Carneiro, Antonio Filippin, Carlo Fiorio, Luca Flabbi, Margherita Fort, Marco Giuliani, Marco Leonardi, Matteo Manera, Francesco Scervini and participants to IWAEE (International Workshop on Applied Economics of Education, Catanzaro, 2011), ISEG (First Lisbon Research Workshop on Economics and Econometrics of Education, Lisbon, 2011), Barcelona (2011) conferences, Georgetown University Microeconomics seminar (2011) are also gratefully acknowledged.
} 


\section{Introduction}

Over the last century, most European countries experienced a general increase in the average level of schooling, and a contemporaneous reduction in the dispersion of educational attainments across the population. Nevertheless, education still remains unequally distributed and highly correlated with family background. The extensive literature on intergenerational mobility has in fact highlighted a strong and persistent link between parents and children educational attainment (see Black and Devereux, 2010, for a review), suggesting that the opportunities remain unevenly spread across the population and that life-chances of individuals reflect factors for which they are not responsible.

The average level of schooling, the dispersion of educational levels and the extent to which individual educational attainment depends on parental background vary extensively across countries and over time, possibly in response to the specific institutional setting in which the school systems operate. Schools have a central role in shaping the ways educational inequalities are generated and perpetuated. Different characteristics of education systems may help reducing (reinforcing) to various extents the advantage of pupils from high socio-economic background, thus decreasing (increasing) educational inequality. Pattern of provision of pre-primary education, duration of compulsory school, school tracking, school choice, the extent of school accountability and autonomy, academic selection, are all features that may affect both the mean and the distribution of educational attainments, thus shaping efficiency and equity of each schooling system. Understanding how and to what extent these institutional features affect countries' accumulation of human capital is crucial from a policy perspective, under the (maintained) assumption of the beneficial effects of education to individuals and societies. ${ }^{1}$

The aim of this paper is to study the impact of school design on education attainment in Europe, using an original dataset collecting information on various reforms that affected the school system over the 1930-2000 period for 24 countries. By school design we mean the institutional set-up that characterizes compulsory and post-compulsory education, starting from pre-primary and ending with tertiary education. Previous literature investigating the role of school institutions on educational attainment has mainly focused on either country-specific episodes, or cross-country evidence, but mostly focussing on single dimensions. In the former approach, the effects of institutional features are identified exploiting the variation of educational policies across regions within a state, or using reforms in the school system and adopting a before-after approach, sometimes also exploiting a gradual introduction that makes the timing of the reform different across different areas. The limit of these case studies is that results are hardly generalisable since it is impossible to disentangle the impact of the educational reform from the entire institutional setting of a specific country. Moreover, since most of the variation in the institutional features of

\footnotetext{
${ }^{1}$ From the individual point of view, more educated people are not only more likely to have better labour market outcomes in terms of employability and wages (see the surveys by Card, 1999 and Harmon et al., 2003), but they also experience better health, fertility, well-being, less probability of engaging in crime and other non-monetary outcomes (see Oreopulos and Salvanes 2011 for a survey on non pecuniary returns - see also Grossman 2006). Moreover, education has wide spill over effects, generating not only private, but also public benefits. Increasing education seems to positively influence also economic growth, social cohesion, citizenship, and political participation (see, for example, Hanushek and Kimko, 2000; Krueger and Lindhal, 2001; Dee, 2004; Milligan et al., 2004; Lochner and Moretti 2004). Conversely, we ignore the issue of over-education, which may suggest that education is not always achieved up to an efficient amount.
} 
schooling systems occur between countries rather than over time, the identification of the impact of school design is difficult using national data only (see also the discussion in Hanushek and Woessmann, 2010). In principle, a cross-country approach seems to be more effective in this perspective, but most of the existing cross-country studies are based on cross-sectional data only (see for example, Woessmann, 2003; Schuetz et al., 2008) making the identification of the effect of school design problematic, since country-specific unobservable factors are likely to bias the results. In the present paper, we exploit variations of the institutional setting across countries and over time, using a rich database that we have collected on a wide set of reforms in 24 countries over the last century. This allows us to control for time-invariant country-specific factors that are possibly correlated with educational achievement and inequality. In addition, we expand the set of institutional dimensions in several directions, from pre-primary education to university access.

Our work extends the existing literature in different directions. First, our database covering over 70 years of reform allows increasing the temporal span of most of the previous studies and to include in the analysis several decades that marked important changes in education provision. Second, while most of the previous empirical works focus on specific types of reforms (duration of compulsory school, school tracking, accountability, to cite the main ones), this paper focuses on a wide range of institutional dimensions that we also try to group in broad indicators of the salient features of an educational system: inclusiveness, compulsoriness, accountability, teacher qualification, student support and university autonomy, to list what seem to us the most relevant ones. Third, we study the existing correlation between these underlying reform orientations and the prevailing political orientations of parliaments and/or governments. Fourth, while most of the existing cross-country literature has investigated the impact of schools' institutional features on pupils' competences, using data from international testing surveys. We instead measure educational attainment in terms of completed years of school and qualification achieved, which allows us to consider the effect of school design for individuals belonging to different age groups without restricting ourselves to specific and (recent) cohorts for which data on competences are available. Fifth, we study not only the average impact of reforms on average educational attainment but also its potential heterogeneity in impact, thus being able to predict their bearing on educational inequality (as measured by dispersion indices computed on the distribution of educational attainment in the population).

The paper is organized as follows. In section 2 we provide a review of the existing literature on school institutions and we discuss the expected effect on school attainment. In Section 3 we present the data, while section 4 illustrates the empirical analysis. Results are discussed in section 5 and finally section 6 concludes.

\section{Educational institutions and schooling outcomes: previous literature and theoretical expectations}

This section reviews the economic literature on the impact of school institutions on educational achievement, largely focussing on cross-country studies. The surveyed papers are grouped according to the specific institutional feature they investigate. In particular, we classify the institutional characteristics of school systems in eight categories: structure and length of preprimary education; length of compulsory education; school tracking; school accountability; school autonomy; teacher qualification; student funding, university autonomy and selectivity. We borrow part of this classification from Krueger and Lindhal (2009); for a general discussion see also OECD (2010). 
For each of these characteristics of the school system, we shall discuss their expected impact on educational attainment and on educational inequality, thus highlighting potential trade offs between equity and efficiency (see also the related discussion in Woessmann, 2008).

\subsection{Pre-primary education}

The economic literature seems to agree on the positive effects of pre-school education on both efficiency and equity of the education system. The theory behind this idea is explained in various models developed by James Heckman and co-authors describing the technology of skill formation (see Cunha et al., 2006; Cunha and Heckman, 2007, 2008 and 2009). Building on the traditional theory of human capital, they model the formation of skills as a life cycle process that exhibits both recursive productivity and dynamic complementarity. Recursive productivity means that the skills acquired at one stage are inputs into the learning process of the next stage, while dynamic complementarity implies that the stock of skill acquired in a period makes the investment in the next period more productive. Therefore investment in education at one stage raises the skills not only directly attained at that stage, but also indirectly the productivity with which educational investments will be transformed into further skills in the next stages. This implies that investments in early education are more productive than those at later stages and can thus increase the efficiency of the following learning process. They also impact on equity as the rates of return to investment in early education tend to be higher for children from disadvantaged families, while at older ages they tend to be higher for children from well-off families (see Cunha and Heckman, 2007 and 2009).

The empirical literature, mainly based on US studies, confirms that interventions in early childhood are generally efficient, especially when targeted at disadvantaged children, and that the positive effects are persistent over time (see the thorough surveys in Currie, 2001, Waldvogel, 2002 and Carneiro and Heckman, 2003). Results for other countries are fewer but tend to reach similar conclusions. For example, Leuven et al. (2010) show that lowering the school starting age in Netherland increased the later educational performance of disadvantaged pupils (ethnic minority pupils and pupils with lower educated parents), thus contributing to reduce inequality ${ }^{2}$. Goodman and Sianesi (2005) find significant and long-lasting effects of pre-compulsory education (preschool or school entry prior to age 5) on educational and labour-market outcomes in Britain, but they do not comment on its differential impact according to children family background. Berlinski et al. (2009) study the effect of a large expansion of universal pre-primary education on subsequent primary school performance in Argentina and find that attending pre-primary school has a positive effect on subsequent cognitive achievement (somewhat higher for children from poor households), but also on behavioural skills such as attention, effort, class participation and discipline.

The cross-country evidence on the topic is significantly scanter. Esping-Andersen (2004) shows that the impact of family background is smaller in countries with extensive pre-school day care. Schuetz et al. (2008) find that the length of a country's pre-school education system is positively associated with cognitive performance in middle school. They also show that more extensive systems of pre-school education - in terms of both enrolment and duration - significantly increase

\footnotetext{
${ }^{2}$ In Netherlands children are allowed to start school the day when they turn four years of age and the authors exploit the fact that the summer break ( 6 weeks) introduces exogenous variation in the age at which children start school.
} 
equality of opportunity, as measured by a lower dependence of eighth-grade students' test scores on their family background.

\subsection{Expansion of compulsory education}

In the empirical literature, compulsory years of schooling have often been used in the context of instrumenting the schooling variable in Mincerian equations and proved to be good predictors of individuals' educational attainment. Most of these papers make use of national microdata and focus on specific countries: see, among others, Angrist and Krueger (1991) for US; Aakvik et al. (2010) for Norway; Harmon and Walker (1995) for UK; Meghir and Palme (1999) for Sweden; Pischke and von Wachter (2008) for Germany.

Few cross-country studies have investigated the impact of compulsory schooling legislation on the actual educational attainment of the population. Brunello, Fort and Weber (2009) exploit the exogenous variation provided by minimum school leaving age laws to identify the effect of education on earnings using data from 12 European countries. They find that compulsory school reforms significantly affect educational attainment ${ }^{3}$, especially among less able individuals. In particular, they show that the effect of compulsory schooling laws on educational attainment is statistically significant for all but the top deciles of the distribution of male education (all but the very top for females) and that the size of this effect declines as they move from the bottom to the top quantile. They explain the significant effect also on individuals with higher educational attainment, by arguing that "better educated individuals react to increases in compulsory schooling by raising their own attainment, possibly in an effort to maintain their educational advantage over the less educated, who are more directly affected by the reforms" (Brunello et al. 2009, p. 517)

Murtin and Viarengo (2011) study the expansion of compulsory schooling in fifteen Western European countries over 1950-2000 and investigate the effectiveness of this policy to increase average education in post-war Europe. They regress the average years of schooling in the population older than 15 in a given country and period onto lagged compulsory years of schooling and show that the increase in compulsory schooling is a robust determinant of current changes in school attainment.

However increased compulsory education can be obtained either by lowering entry age or rising exit age. Dobkin and Ferreira (2010) argue that despite the lower academic performance of early entrants, they stay in school longer, the two effects offsetting each other. As a consequence they do not find significant net effect on adult labour market outcomes of lowering entry age (at kindergarten level) in a sample of US population. On the other side, combining data from US, UK and Canada at state/region level Oreopulos (2007) shows that rising school leaving age is beneficial in terms of lifetime wealth, health and happiness.

\footnotetext{
${ }^{3}$ More specifically, their results show that the increase in compulsory schooling induced by the reforms leads to about 0.3 additional years of schooling, with little cross country variation.
} 


\subsection{School tracking}

School tracking is a specific aspect of school stratification (or differentiation). A school system is characterised by tracking when children are allocated - at some stages of their career - to different tracks, characterised by different curricula offered (generally distinguishing between academic or vocational education) and different average ability of the enrolled students. School tracking introduces therefore a selection in the schooling process either in the form of selfselection or in the form of admission based on ability tests (Brunello and Checchi, 2007).

National school systems differ widely in the amount of ability tracking of students they provide in school: in the age at which the selection takes place, in the degree of differentiation, in the share of students attending one track. In the majority of OECD countries, tracking takes place at age 15 or 16, but in other countries the first tracking occurs much earlier (at age 10 in Austria and Germany, at age 11 in Czech Republic, Hungary and Slovakia, at age Netherlands and Belgium at 12) ${ }^{4}$.

Available justification of tracking refer to the idea that for teachers it is easier to teach to homogeneous classes, as this helps to focus their teaching to a level appropriate to most students in the class, implying an increase in school system's efficiency. However, while the efficiency gains of tracking are yet not proved, early tracking may entail costs in terms of equity. In fact, when students are allocated to separate schools according to their ability, more able pupils will benefit from being with each other ${ }^{5}$, while low ability pupils loose from not having this peer group around (see Manning and Pischke, 2006, for a discussion). If different school types are hierarchically structured by performance, the learning of disadvantaged students allocated to lower tracks may be hampered by poorer educational quality and the lack of benefits from peer group (OECD, 2007). Early tracking is thus likely to affect educational inequality, since it reinforces the ability gaps between pupils coming from different family backgrounds.

The empirical evidence has generally confirmed the inequality enhancing effect of early school tracking, while the evidence on efficiency is more mixed. Both Hanushek and Woessmann (2006) and Ammermuller (2005) adopts similar identification strategy (differences-in-differences approach using PISA and PIRLS) finding that tracking increases educational inequality. Similar conclusions are reached by Schuetz, Ursprung and Woessmann (2008) who estimate the effect of different education policies, including school tracking, on equality of educational opportunity in 54 countries. All these analysis are based on student samples surveyed in the last decade or so. ${ }^{6}$

When looking at life time consequences of tracking, Brunello and Checchi (2007) show that the negative effect of early school tracking on equality of opportunity persist beyond the school age, reducing intergenerational mobility. More recently, Hanushek, Woessmann and Zhang (2011) have shown that having attended vocational schools (at secondary or tertiary level) provides an advantage in the short run (represented by a higher probability of employment), which decays

\footnotetext{
${ }^{4}$ Information on age at first tracking is available from Eurydice (http://eacea.ec.europa.eu/education/eurydice/index en.php)

${ }^{5}$ For evidence on peer effects on students' achievement see Hoxby (2000b) and Hanushek et al. (2003).

${ }^{6}$ Results in contrast with the previous literature can be found in Vandenberge (2006), which studies the impact of different measures of school stratification (extent of tracking, grade repetition and interschool segregation) on educational performance using test scores data from PISA 2000. His results show that stratification does not affect school effectiveness (mean score) nor intensity of inequality (dispersion of scores among students).
} 
during the life course; for some countries, vocational education is also associated to a wage penalty. They suggest that academic/general education (concept based) may favour adaptability to innovations in production, especially when compared to skill-based education.

Overall, the cross-country literature suggested that early tracking accentuates the role of family background on pupils' attainment and therefore increases educational inequality. It has also points to the dis-equalising effects of tracking beyond school age, affecting labour market transition and life time income. In contrast, we are not aware of robust evidence finding beneficial effects of tracking as a mean to increase average performance. ${ }^{7}$

\subsection{School accountability}

Pupils' educational attainment can also be affected by the extent of school accountability, generally proxied by the presence or not of external exit exams. As summarised in Woessmann (2007), cross-country evidence indicates that introducing accountability by externally testing and making students' and schools' exams public creates incentives to improve educational performance (see also Bishop 1997, 2006; Jürges et al. 2005; Woessmann, 2003, 2005). The results of centralised standardised exams, by being more comparable, are more valuable as signals on the job market than the results of non-central examinations. In addition, student test results can be also used to monitor teacher and teaching quality on a regular basis and the reputation of entire schools can be based on the achievement of its students, with good schools attracting good students when the results of the tests are made public (Jürges et al. 2005).

Over the last decades forms of accountability have been introduced in many countries to raise school performance. However, the impact of these policies in terms of inequality and other aspects than performance are not clear yet. Hanushek and Raymond (2003) review the literature discussing the unintended consequences that accountability has produced: (average) teachers have reacted by narrowing their teaching focus to better performing students, ignoring other aspects of pupils' development. More importantly, public disclosure of school performance has increased their exposure; schools have become more selective, and aim at choosing the best students, in order to improve school scores, not necessarily changing the quality of the teaching. If school accountability policies are ill-designed, namely based on performance levels rather than value-added, they may give undue advantages to schools serving students from high socioeconomic backgrounds (Ladd and Walsh, 2002; Schuetz, West and Woessmann, 2007). Even in the case when they are based on value added, schools may still have an incentive to exclude disadvantaged students from official exams and place them in special education or counsel them to be absent on the days of testing. ${ }^{8}$

These mechanisms have clearly negative consequences in terms of equity, since they imply more exclusion, higher dropout rates, and a narrowing of the curriculum. However there is a scarcity of empirical works that have specifically looked at the impact of accountability on educational inequality. For the US, Hanushek and Raymond $(2004,2005)$ find a positive impact of school accountability on average students' achievement; in terms of distributional effects, they show that

\footnotetext{
${ }^{7}$ These results are largely confirmed by the empirical evidence based on country specific studies: see for example, Dustmann (2004) for Germany; Bauer and Riphahn (2006) for Switzerland; Meghir and Palme (2005) and Holmlund (2008) for Sweden; Pekkarinen et al. (2006) for Finland and Galindo-Rueda and Vignoles (2004) for UK.

8 Indeed many studies for the US have in fact confirmed that schools reacted to accountability through exclusions, increases in special education placement and increased grade retentions (see for example Jacob, 2005).
} 
this effect varies by population subgroups, with Hispanics gaining most and Blacks gaining least. Cross-country evidence is provided by Woessmann (2005): using student-level data from three international student test surveys (TIMSS, TIMSS repeated and PISA), he analyses the impact of external exit exams on student performance and finds heterogeneous effects depending on students' backgrounds, students' ability and schools' specific settings, as well as increasing effects over the course of secondary education. Using also quantile regressions to estimate the effect of central exams on student performance for students at different points on student ability distribution, he finds that the positive impact of central examination in performance is stronger for high ability students, which would tend to widen the achievement distribution.

Overall, the literature agrees on positive effect of accountability systems (in particular central examinations) on student performance, which is explained by stimulating effort of better performing students. As a consequence, inequality in outcomes may rise as a result of these measures.

\subsection{School autonomy}

School autonomy (or decentralisation of decision making power) is also expected to exert positive effects on student outcomes, because local decision-makers tend to have superior information than central government. On the other hand, where their interests are not strictly aligned with improving student achievement, local decision-makers may act opportunistically unless they are held accountable for the achievement of their students (see Woessmann 2005) for a discussion of this topic in a principal-agent framework).

Country case studies (like New Zealand) that shifted towards a greater extent of school autonomy express caution in assessing the aggregate benefits of such an innovation, due to increased stratification of the national schooling system (Fiske and Ladd 2000). Few empirical papers have studied the role of school autonomy in a cross-country framework. Woessmann et al. (2009) (see also Woessmann 2003 and Fuchs and Woessmann 2007) show that students perform significantly better in schools that have autonomy in process and personnel decisions (such as purchase of supplies, budget allocations, hiring and rewarding of teachers, textbooks choice, instructional methods, and the like). Similarly, students perform better if their teachers have both incentives and possibilities to select appropriate teaching methods. By contrast, school autonomy in budget formation and teacher autonomy over the content to be covered in class - two decision-making areas that are likely subject to substantial opportunism but little superior local knowledge - are negatively associated with student achievement.

Woessmann et al. (2009) also find that the effect of school autonomy depends on the extent of accountability that affects the incentive for opportunistic behaviours. In particular, when they interact measures of autonomy with measures of accountability, they show that school autonomy is negatively associated with student achievement in systems without external exit exams (low accountability), but the association turns into positive when combined with external exit exams. No clear results are obtained over the distributions of test scores. 


\subsection{Teacher qualifications}

Measuring teaching quality is complicated because the most common observable teachers' characteristics (such as gender, age, qualifications or experience) appear to be relatively uncorrelated to (unobservable) teachers' quality as estimated from students' testing scores, once family and school effects are taken into account (Krueger, 1999; Rivkin, Hanushek, and Kain, 2005). There is a large literature that investigates the role of teacher quality and teacher incentives in improving educational outcomes, considering as outcome of interest test scores (Hanushek and Rivkin, 2006 - for a review on teacher incentives see Lazear 2003).

The possibility of attracting better applicants into the profession, combined with stimulating their effort through appropriate wage policies, explains the observed correlation between teachers pay and students performance observed in a cross-country perspective (Dolton and MarcenaroGutierrez, 2011). Most of the recent policy recommendations to improve educational systems point to attracting, motivating and retaining good teachers. There is significant differences in country practices with respect to admission to the profession (national exams, university certification, on the job training), to mentoring at the beginning of the career and to improve professional development throughout the career (OECD 2005).

\subsection{Student financing}

Several studies have suggested that liquidity constraints may prevent the children of poorer households from proceeding in their educational career up to secondary and tertiary levels (Carneiro and Heckman 2002; for a recent review of the literature see Lochner and MongeNaranjo 2011). The empirical difficulty in assessing the extent of constrainedness is related to disentangling the contribution of other factors (either biological and/or cultural) to generating intergenerational dependence of children choices from parental conditions.

Without a clear understanding of how financial constraints works in limiting the choice set (through heterogeneity in risk aversion correlated with wealth possession ? through debt aversion ? through financial market imperfections ? through lack of collaterals ? through imperfect information about future potential gains ?), it is difficult to assess which are the most effective policies to increase the equality of opportunities. Chapman (2006) reviews the main arguments in support of public interventions to reduce financial constraints and/or the risk associated to the educational investment. He argues that (almost full) subsidisation of tertiary education (through low or nil tuitions fees, as prevalent in many European countries) is fiscally regressive and not equitable from a social point of view. On the other extreme, full cost charged onto individual students, with publicly guaranteed loans to students, may reduce college attendance, disproportionately among poorer backgrounds. In his view both extremes can be avoided by resorting to income contingent loans (often indicated in policy debate as graduate tax). ${ }^{9}$ Olivera et al. (2007) reviews the existing student loan situation in most OECD countries, showing that when available, loan systems are designed not only to limit individual financial risks but also to provide a direct subsidy (through interest rate subsidisation, high income thresholds for repayment and long amortisation period). Despite this, in many countries the take-up rate remains low, students

\footnotetext{
${ }^{9}$ In addition to the Australian experience (originally Chapman 1997), there have been a flourishing of national case study assessments (the UK experience is discussed in Dearden et al. 2008 and 2011) or evaluations (the German case discussed by Chapman and Sinning 2011).
} 
preferring part-time work as alternative source of funding. The alternative of student grants has universal coverage only in a limited number of countries (US, Scandinavia, Netherlands). They also show that the ratio of direct costs to available funds from alternative sources (loans, grants, family income) is a significant predictor of graduation rates in a panel sample of 19 OECD countries over the period 1992-2002.

\subsection{University autonomy and selectivity}

There is a wide and mostly descriptive literature on cross country differences in university governance (Teichler 2007, Eurydice 2008). Most European countries experienced a significant expansion in tertiary education enrolment in the recent decades, without sizeable changes in the internal organisation. The vast majority of European universities are centrally organised and financed, and this reduce the internal degree of competition, especially when compared to US universities. Jacobs and van der Ploeg (2006) have clearly described the outcome of such framework: "European universities seem more comfortable providing a decent education for all with not much selection based on national exams and/or interviews or exams set by the universities themselves. Of course, abstaining from selection may be a legitimate policy choice, but it hurts efficiency and excellence. One big consequence is that there will be less competition on academic excellence among secondary schools, especially if there is no national exam or the national exam only sets a minimum standard." (p.557). They advocate a greater internal differentiation among European universities, in terms of mission, funding and student selection. This can be accomplished by shifting funding to students and diminishing governmental control.

More recently, Aghion et al. (2010) have shown that increased managerial autonomy goes hand in hand with greater competition, yielding higher scientific productivity (measured by impact-ranked publications). They notice that from a governmental point of view it would not make sense to provide greater autonomy to universities without any check and balance, ${ }^{10}$ while increasing the degree of competition (for example by fostering private initiatives in tertiary education) without rendering universities capable to react may be just frustrating. Autonomy extends to several aspects of university organisation: procedures for budget approval, hiring and salary setting for faculty, student admission policies, diversification of funding sources.

Less attention has been paid to the implications of increased university autonomy onto student access. By observing the American market for tertiary education, it is an easy prediction that increased autonomy/competition among European universities will lead to increased selectivity in admission to better universities, which will be probably accompanied by rising tuitions as well as expected wages (for a review of the US experience se Hoxby 2009). Less clear is the overall impact, since a raise of the signalling value of tertiary degrees may be accompanied by a rising number of applicants and/or by a rising number of seats. Even more uncertain may be the implications with respect to equality of opportunities. ${ }^{11}$

\footnotetext{
10 Though the Italian experience of the Bologna process reform suggests that this event may occur, leading to an uncontrolled expansion of teaching (with a potential - yet unmeasured - decline in productivity), aimed to attracting more students and seizing a larger fraction of public resources (Bertola and Checchi 2010).

${ }^{11}$ This may not be a problem, at least according to one of the final policy proposal in Jacobs and van der Ploeg (2006): "Abolish equity issues from higher education. Although equity arguments feature prominently in discussions of higher education, they are not convincing. Subsidies on higher education are after all regressive." (p.583). However, few lines below, the same authors also advocate "Do not raise and differentiate tuition fees or select students without an income-contingent loan scheme. Without income-contingent loans to warrant accessibility, allowing HEls to set their
} 


\subsection{Discussion and summary}

We summarise the main findings of the previously reviewed literature in table 1 . If we consider a standard model of optimal educational choice (Card 1999), rational agents choose to stay in school up to the point when the marginal cost equates the marginal benefit, conditional on not being financially constrained. The area of educational reforms affects this optimality condition through four possible channels:

1) compelling students to school (which is typically enforced when there are no outside options)

2) lowering costs of attendance (both monetary and/or psychological ones)

3) relaxing financial constraints (mostly relevant for tertiary education)

4 ) increasing marginal return of education through an improvement of the quality of schooling.

If these effects are heterogeneous in the population, then the reforms also have an impact on the distribution of educational attainment.

Table 1: Educational reforms and expected impact on educational attainment

\begin{tabular}{|c|c|c|}
\hline area of reform & affecting investment in education & expected impact \\
\hline pre-primary education & $\begin{array}{l}\text { enhances productivity of later school } \\
\text { stages (education begets education) - } \\
\text { lower costs of subsequent attendance }\end{array}$ & $\begin{array}{l}\text { student stay in school longer (more in } \\
\text { the case of poor backgrounds) }\end{array}$ \\
\hline expansion of compulsory education & avoids early drop-out (for compliers) & $\begin{array}{l}\text { student stay in school longer (effects } \\
\text { concentrated in the case of poor } \\
\text { backgrounds) }\end{array}$ \\
\hline school tracking & $\begin{array}{l}\text { better matching of abilities and/or } \\
\text { backgrounds enhances peer effects - } \\
\text { increase return (academic) and lower } \\
\text { cost (vocational) }\end{array}$ & $\begin{array}{l}\text { uneven effects on mean and variance } \\
\text { (academic stay longer, vocational stay } \\
\text { shorter but drop-out less) }\end{array}$ \\
\hline school accountability & $\begin{array}{l}\text { more efficient use of resources may } \\
\text { raise quality of education - increase } \\
\text { return may affect only parents who } \\
\text { are aware of quality issues }\end{array}$ & $\begin{array}{l}\text { uneven effects at mean, but increased } \\
\text { variance, due to possible screening } \\
\text { and/or sorting. of students }\end{array}$ \\
\hline school autonomy & $\begin{array}{l}\text { adapting teaching to the social } \\
\text { environment may lower costs of } \\
\text { attendance - ambiguous effect on } \\
\text { quality, especially in the absence of } \\
\text { centralised control }\end{array}$ & $\begin{array}{l}\text { ambiguous effects on returns - } \\
\text { possible uneven effects on the } \\
\text { distribution }\end{array}$ \\
\hline teacher qualification & $\begin{array}{l}\text { increases quality of education and } \\
\text { raises the expected return of human } \\
\text { capital in the labour market }\end{array}$ & $\begin{array}{l}\text { ambiguous effects on mean staying - } \\
\text { richer backgrounds may take } \\
\text { advantage, because of better access to } \\
\text { information }\end{array}$ \\
\hline student financing & $\begin{array}{l}\text { lower cost of attendance and/or } \\
\text { reduces the risk associated to higher } \\
\text { education }\end{array}$ & $\begin{array}{l}\text { positive mean impact because of more } \\
\text { students in higher education (mostly } \\
\text { from financially constrained families) }\end{array}$ \\
\hline university autonomy and selectivity & $\begin{array}{l}\text { raises the signalling value of tertiary } \\
\text { education, and the associated } \\
\text { expected earnings }\end{array}$ & $\begin{array}{l}\text { uneven effects (stronger competition } \\
\text { to access better universities may } \\
\text { translate in discouragement in the } \\
\text { bottom tail) }\end{array}$ \\
\hline
\end{tabular}

own pricing and selection policies will result in cream-skimming of the best and, more importantly, the wealthiest students. and there will be too many smart and poor students in low-quality universities." (p.584). 
There are other institutional dimensions which we have been unable to consider, not because they were less important, but simply because we were unable to collect information with sufficiently longer time span and/or country coverage. Let us list the few of them which we would have liked to include. There is significant variation in instructional time across countries, especially when cumulated over multiple years $^{12}$, but we could not find time series for this variable going backward before 90's. Other measures of school inputs (like class sizes) have been analysed in cross-country framework, without conclusive results (Woessmann and West 2006; see reviews in Hanushek and Woessmann 2010 and Meghir and Rivkin 2010). School competition has received attention in the literature, following the argument that increasing parents' choice set forces schools to compete for students and induces incentives to improve their performance (Rouse and Barrow, 2009 - see the review in Hoxby 2003). However the evidence on the effects of competition on school performance and efficiency is mixed and generally shows that gains from competition are modest and difficult to identify. ${ }^{13}$ Also teacher practices are relevant for the values that they instil in the students, which may affect incentives or discouragements for student achievements (Bratti, Checchi and Filippin 2011, Algan, Cahuc and Shleifer 2011). Other institutional features that affect class composition and (potential) peer effect are the practice of grade repetition, namely students held back an additional year when they do not reach the expected thresholds (even within compulsory education - see OECD 2007). Similarly, we would have liked to account for policies of class formation, which reflect geographical segregation and self-selection of students (Card and Rothstein 2007). Finally other papers have studied the cross-country correlations between test scores and national institutional features related to resource availability (educational expenditure, student/teacher ratios, teacher pay and qualification) but identification of causal effects remain s problematic (Causa and Chapuis 2009).

Even if one could account for actual practices inferred from actual data, it is impossible to go backward for more than two decades. On the contrary, we make use of representative samples of the entire population to obtain the whole distribution of years of education across country and age cohorts. This has at least two advantages. When compared to interpolation of census years through permanent inventory methods (as done in Barro and Lee 2010) we gain more detailed information about intermediate degrees, which may also have changed overtime (in terms of length of curricula and admission). Given the information available, we also take into account failed attempt and/or early drop out events, which typically remain hidden when using the

\footnotetext{
12 Lavy 2011 reports evidence of impact of instructional time onto test scores in cross-country analysis of PISA 2006, as well as in an Israeli dataset. Mandel and Süssmuth 2011 show that variation across German länder may account for differences in student test scores at $9^{\text {th }}$ grade.

${ }^{13}$ Most of this empirical analysis is based on country-specific analysis and mainly focused on US and UK. While some works find that enhanced school choice is not associated with more 'cream skimming' and segregation (e.g. Hoxby, 2000a for the US and Gorard, Taylor and Fitz, 2003 for England), most of the papers show that greater competition arising from parental choice led to increased inequality between schools and thus higher social stratification (see among others, Rothstein, 2006 for the US; Gibbons and Silva, 2006, and Allen, 2007 for UK). Cross-country evidence on the effect of school competition on educational inequality is scant, possibly due to the scarcity of comparable data on school competition at the international level. Some works have studied the effects of school competition by measuring it in terms of private school enrolment (the idea is that in countries where there are a large number of private schools, public schools face more competition - Woessmann 2003 and 2008, Woessmann, Lüdemann, Schütz, and West 2009). However these studies have to address the potential endogeneity of private enrolment. West and Woessmann (2010) address the endogeneity issue using the share of Catholics in 1900 as an instrumental variable for a country's contemporary share of private schools and are able to identify the causal effect of competition from private schools on student achievement. Their results - based on PISA 2003 data - indicate that the share of schools that are privately operated has a significant positive effect on student achievement in mathematics, science, and reading.
} 
maximal educational attainment as unique source of information. The other advantage is that we obtain information on educational attainment back to the beginning of previous century. When survival rates are correlated with education, this may constitute an overestimate of the educational attainment of the entire population, which can be partially offset by top-censoring our data on age (which however do not change results significantly).

The main drawback is that we take into account only the quantity dimension of human capital, while we would have liked studying the evolving distribution of competences across the age cohorts. The only existing surveys, offered by IALS and ALL, have too few observations per cell when we disaggregate by age, gender and educational attainment. As many scholars in the field, we are looking forward to repeat our analysis when PIACC data will be made available in $2013^{14}$.

\section{Data and Descriptive Statistics}

Our analysis combines microdata drawn from four international surveys (European Social Survey, European Union Statistics on Income and Living Conditions, International Adult Literacy Survey, and International Social Survey Programme) with a newly created dataset collecting information on several institutional reforms of school systems over the last 70 years. Our sample includes 24 European countries/regions (Austria, Belgium (Flanders), Belgium (French), Czech Republic, Germany, Denmark, Estonia, Great Britain, Greece, Finland, France, Hungary, Ireland, Italy, Latvia, Northern Ireland, Norway, Netherlands, Poland, Portugal, Slovak Republic, Slovenia, Spain, Sweden) observed over the 1930-2000 period. In the following two sub-sections we describe our original dataset on school institutions (section 3.1) and the microdata on individual educational attainment used for the analysis (section 3.2).

\subsection{A dataset on educational reforms}

In institutional comparative analysis it is always difficult to provide a thorough and concise description of the salient features of a (national) system, and the same trouble concerns the analysis of educational systems. In addition, if institutional aspects have to be correlated with outcome dimensions (like educational attainment, employment probability, wage or health), they need to be measured on a quantitative scale, either ordinal or cardinal. A well-established methodology consists of identifying the salient features of an institutional practice, assigning a subjective score to each feature and aggregating them into a single index. ${ }^{15}$ Another strategy consists of counting the reform events, signing the intended direction of the reform (Bertola and Ichino 1995). If we exclude Oliveira et al. (2007), at the best of our knowledge we are not aware of other attempts to build summary indexes capable to account for salient features of national educational systems. ${ }^{16}$ Despite a wide information available for each country (think of the various

\footnotetext{
${ }^{14}$ However, a potential problem when using these datasets to measure competences for different birth cohorts is that competences and skills - opposite to formal education - change over the life course, making it difficult to separate the cohort effect and the age effect.

${ }^{15}$ This is for example the methodology adopted by the OECD in measuring the supply of tertiary education (Oliveira et al. 2007), the employment protection legislation (OECD 2004a), the degree of wage coordination (OECD 2004b) and the product market regulation (Nicoletti et al. 2000).

${ }^{16}$ On the contrary this is a common practice in the sociological literature, where however educational systems are characterised by indexes obtained by aggregating individual behaviour, thus exposed to the objection of endogeneity. See for example Shavit et al. 2009 or Bol and vanWerfhorst 2011.
} 
issues of Education at a Glance published by the OECD), it is not easy to aggregate single measures, especially when input, process and output variables are all mixed.

In the present paper we pursue a different strategy. We abandon the idea of being able to fully characterise a (national) educational system by means of level indicators: while everyone may be convinced that 10 years of compulsory education is better than 8 years, it is almost impossible to ascertain whether one country is requiring more teacher qualification than another. Conversely everyone agrees on the fact that introducing (or raising) teacher required qualification should improve the quality of the education provision. Thus we combine level measures (age and duration of compulsory education, tracking age) with temporal variations associated to the occurrence of school reforms in a specific country/year. The level dimension is anyhow absorbed by country fixed effect, while cohort effects and time trends are also absorbed by birth year fixed effect and country specific time trend. The remaining variations (along a longitudinal dimension) should identify the impact of each institutional dimension of the educational system, from kindergarten to university.

Information on the historical development of each national education system is drawn from different sources. Our primary source is the Eurybase, the Eurydice database (www.eurydice.org) that provides detailed information on European education systems and policies. In particular, we used country-specific descriptions of national education systems ${ }^{17}$ and thematic studies on specific institutional features (see Appendix A for a description of the reforms included in the analysis and the related sources). We integrate this information using other international sources, such as the United Nations Educational, Scientific and Cultural Organization (UNESCO) country reports, or OECD Education at a Glance, and using country specific documents and direct contact with national experts.

The resulting original dataset contains yearly observations over the 1930-2000 period for 24 countries on 19 institutional features of countries' school systems. The specific types of institutional features and reforms considered in the paper are summarised in Table 2, which also specifies the age that we assume individuals be initially affected by the reform. In the last column we have also indicated broad categories describing the aim of the reform, as we could infer from the available literature presented in the previous section.

\footnotetext{
${ }^{17}$ National Education System Descriptions are highly detailed reports on education systems covered by the Eurydice Network and updated annually by the National Units in the Network. Each country description is structured into 11 subject-based chapters: 1. Political, social and economic background and trends; 2.General organisation of the education system and administration of education; 3. Pre-primary education; 4. Primary education; 5. Secondary and post-secondary non-tertiary education; 5 . Tertiary education; 6 . Continuing education and training for young school leavers and adults; 7. Teachers and education staff; 8. Evaluation of educational institutions and the education system; 9. Special education support; 10. The European and international dimension in education. The reports also contain a summary of relevant legislation, a list of institutions, a glossary and a bibliography round off the description of each education system.
} 
Table 2: Institutional Features of education systems: list and description

\begin{tabular}{|c|c|c|c|}
\hline REFORM & DESCRIPTION & $\begin{array}{c}\text { TARGET } \\
\text { POPULATION }\end{array}$ & $\begin{array}{c}\text { REFORM } \\
\text { ASPIRATION }\end{array}$ \\
\hline $\begin{array}{l}\text { Pre-primary } \\
\text { expansion }\end{array}$ & $\begin{array}{l}\text { Fees reduction; construction of new pre-primary schools; laws obliging to } \\
\text { make pre-primary school available to all citizens; incorporation of pre- } \\
\text { school into schooling systems }\end{array}$ & age 3 & universalism \\
\hline $\begin{array}{l}\text { Pre-primary school } \\
\text { teacher qualification }\end{array}$ & $\begin{array}{l}\text { Increase educational requirement to be employed as a pre-primary school } \\
\text { teacher }\end{array}$ & age 3 & quality assurance \\
\hline $\begin{array}{l}\text { Duration } \\
\text { compulsory } \\
\text { education }\end{array}$ & Number of years of compulsory school & age 10 & universalism \\
\hline $\begin{array}{l}\text { Beginning age of } \\
\text { compulsory } \\
\text { education }\end{array}$ & Entry age into compulsory formal education & age 6 & universalism \\
\hline $\begin{array}{l}\text { Leaving age of } \\
\text { compulsory } \\
\text { education }\end{array}$ & Leaving age from compulsory formal education & age 10 & universalism \\
\hline $\begin{array}{l}\text { Primary school } \\
\text { teacher qualification }\end{array}$ & $\begin{array}{l}\text { Increase educational requirement to be employed as a primary school } \\
\text { teacher }\end{array}$ & age 6 & quality assurance \\
\hline $\begin{array}{l}\text { Secondary school } \\
\text { teacher qualification }\end{array}$ & $\begin{array}{l}\text { Increase educational requirement to be employed as a secondary school } \\
\text { teacher }\end{array}$ & age 10 & quality assurance \\
\hline Tracking age & Age at first tracking & age 10 & $\begin{array}{c}\text { universalism/ } \\
\text { selectivity }\end{array}$ \\
\hline $\begin{array}{l}\text { Standardised test } \\
\text { (for career } \\
\text { advancement) }\end{array}$ & $\begin{array}{l}\text { Presence of national standardised tests for taking decisions about the } \\
\text { school career of pupils }\end{array}$ & age 6 & $\begin{array}{l}\text { accountability/ } \\
\text { selectivity }\end{array}$ \\
\hline $\begin{array}{l}\text { Standardised test } \\
\text { (for other purposes) }\end{array}$ & $\begin{array}{l}\text { Presence of national standardised test for other purposes(e.g. measuring } \\
\text { performance of schools) }\end{array}$ & age 6 & accountability \\
\hline School evaluation & $\begin{array}{l}\text { Creation of structures for the steering and evaluation of its education } \\
\text { system; carrying out of independent external inspections and evaluations; } \\
\text { legislations strengthening the importance of school evaluation; } \\
\text { measurement of school performance through the testing of samples of } \\
\text { students }\end{array}$ & age 6 & accountability \\
\hline School autonomy & $\begin{array}{l}\text { Reforms increasing autonomy in school management and decision-making } \\
\text { processes }\end{array}$ & age 6 & autonomy \\
\hline Teacher autonomy & $\begin{array}{l}\text { Increase degree of autonomy for teacher in primary and secondary } \\
\text { education }\end{array}$ & age 6 & autonomy \\
\hline $\begin{array}{l}\text { Selectivity in } \\
\text { university access }\end{array}$ & $\begin{array}{l}\text { Introduction of admission tests; introduction of national exam for entry to } \\
\text { higher education; entrance to higher education based on candidates' marks } \\
\text { at exit of secondary school }\end{array}$ & age 15 & selectivity \\
\hline $\begin{array}{l}\text { Expansion of } \\
\text { university access }\end{array}$ & $\begin{array}{l}\text { Open access from vocational high schools; geographical expansion of } \\
\text { universities; creation of polytechnic institutions providing non-university } \\
\text { vocational higher education }\end{array}$ & age 15 & universalism \\
\hline Increase grant size & Increase financial support at tertiary level through grant & age 15 & universalism \\
\hline $\begin{array}{l}\text { Loan component to } \\
\text { grant component }\end{array}$ & $\begin{array}{l}\text { Dimension of the loan component to the grant component for financial } \\
\text { support at tertiary level }\end{array}$ & age 15 & $\begin{array}{l}\text { universalism/ } \\
\text { selectivity }\end{array}$ \\
\hline Interest rate & Interest rate charged to loans for tertiary education & age 15 & universalism \\
\hline $\begin{array}{l}\text { Index of university } \\
\text { autonomy }\end{array}$ & $\begin{array}{l}\text { Autonomy at tertiary level in the following dimensions: budget, } \\
\text { recruitment, organization, logistic, courses organization, self - evaluation } \\
\text { and development plans }\end{array}$ & age 15 & $\begin{array}{l}\text { selectivity / } \\
\text { accountability }\end{array}$ \\
\hline
\end{tabular}

Table 3 reports some summary statistics of the reform variables and it also indicates whether a variable is measured in levels (age and duration of compulsory education, tracking age) or as an index (taking a value of zero in the absence of a specific aspect and a value of one when it is present). When legislators have repeatedly reformed a specific dimension over the sample period, we created step dummies, which are then summed over the years, with a final normalisation yielding a unitary range of variation. ${ }^{18}$ The final variable "Index of university autonomy" is the sum

\footnotetext{
${ }^{18}$ To make an example, take the case of "Pre-primary expansion" in Finland: we find record of significant reforms over this dimension in 1973, in 1985 and in 1999. We therefore construct a variable, which is zero before 1973, $1 / 3$
} 
of indexes characterising seven separate dimensions (budget, recruitment, organization, logistic, courses organization, self-evaluation and development plans), which are then rescaled in order to retain unitary variation. Notice that the decomposition of the standard deviation into the "between" and the "within" components indicate that there is sufficient variation within countries. For some variables related to university access we lack information for 7 newly entrants in the European community (Czech Republic, Estonia, Hungary, Latvia, Poland, Slovak Republic, Slovenia)

In Table 4 we report the pairwise correlation matrix. Since most of the variables are increasing because the European countries underwent waves of opening up to mass access (think of the French 1968 student revolt), most of the variables exhibit positive correlation (except with the "beginning age of compulsory education", which by construction is negatively correlated with the increase in access to education). In the ensuing section 5 we also apply principal component analysis in order to cope with the potential multicollinearity (especially for the index of university autonomy) as well as to reduce the dimensionality of the reform aspect, identifying six dimensions which in our view characterise modern educational systems. However, in order to convince the reader about a genuine impact of each variable, we first proceed by presenting the impact of each of the 19 reform indicators onto individual educational attainment, and then we move to the six summary measures.

Table 3: Descriptive Statistics of the variables describing national school systems $\mathbf{- 1 9 2 9 - 2 0 0 0}$

\begin{tabular}{|c|c|c|c|c|c|c|c|c|}
\hline & Mean & $\begin{array}{l}\text { Std. Dev. } \\
\text { (overall) }\end{array}$ & $\begin{array}{l}\text { Std. Dev. } \\
\text { (between) }\end{array}$ & $\begin{array}{l}\text { Std. Dev. } \\
\text { (within) }\end{array}$ & Min & $\operatorname{Max}$ & Obs. & $\begin{array}{c}N . \text { of } \\
\text { countries }\end{array}$ \\
\hline Pre-primary expansion & 0.396 & 0.451 & 0.233 & 0.389 & 0 & 1 & 1728 & 24 \\
\hline Pre-primary teacher qualification & 0.272 & 0.400 & 0.215 & 0.341 & 0 & 1 & 1728 & 24 \\
\hline Duration compulsory school & 8.146 & 1.871 & 1.100 & 1.530 & 3 & 13 & 1728 & 24 \\
\hline Beginning age of compulsory education & 6.376 & 0.761 & 0.705 & 0.320 & 4 & 9 & 1728 & 24 \\
\hline Leaving age of compulsory education & 14.522 & 1.658 & 0.860 & 1.428 & 10 & 18 & 1728 & 24 \\
\hline Primary teacher qualification & 0.352 & 0.417 & 0.200 & 0.368 & 0 & 1 & 1728 & 24 \\
\hline Secondary teacher qualification & 0.402 & 0.446 & 0.235 & 0.381 & 0 & 1 & 1728 & 24 \\
\hline Tracking age & 13.119 & 2.268 & 1.687 & 1.555 & 6 & 16 & 1728 & 24 \\
\hline Standardised tests (for career advancement) & 0.120 & 0.316 & 0.203 & 0.246 & 0 & 1 & 1728 & 24 \\
\hline Standardised tests (for other purposes) & 0.104 & 0.305 & 0.157 & 0.263 & 0 & 1 & 1728 & 24 \\
\hline School evaluation & 0.121 & 0.323 & 0.100 & 0.307 & 0 & 1 & 1728 & 24 \\
\hline School autonomy & 0.181 & 0.383 & 0.167 & 0.347 & 0 & 1 & 1728 & 24 \\
\hline Teacher autonomy & 0.211 & 0.408 & 0.245 & 0.330 & 0 & 1 & 1728 & 24 \\
\hline Selectivity in university access & 0.378 & 0.471 & 0.359 & 0.317 & 0 & 1 & 1224 & 17 \\
\hline Expansion of university access & 0.317 & 0.421 & 0.163 & 0.390 & 0 & 1 & 1728 & 24 \\
\hline Increase grant size & 0.539 & 0.165 & 0.065 & 0.152 & 0.25 & 1 & 1224 & 17 \\
\hline Loan component to grant component & 0.275 & 0.280 & 0.270 & 0.097 & 0 & 1 & 1224 & 17 \\
\hline Interest rate & 0.275 & 0.275 & 0.270 & 0.083 & 0 & 1 & 1224 & 17 \\
\hline Index of university autonomy & 0.16 & 0.27 & 0.09 & 0.26 & 0 & 0.86 & 1296 & 18 \\
\hline
\end{tabular}

between 1973 and 1984, 2/3 between 1985 and 1998 and 1 afterward. We then match this variable to individuals born 3 years earlier (since the reform is assumed to affect students when 3 year old): those born earlier than 1970 will get a 0 value for this reform, and so on. 
Table 4: Pairwise correlation between reform measures -24 countries - 1929-2000

\begin{tabular}{|c|c|c|c|c|c|c|c|c|c|c|c|c|c|c|c|c|c|c|c|}
\hline & $\begin{array}{c}\text { Pre- } \\
\text { primary } \\
\text { expansion }\end{array}$ & $\begin{array}{c}\text { Pre- } \\
\text { primary } \\
\text { teacher } \\
\text { qualificati } \\
\text { on }\end{array}$ & $\begin{array}{l}\text { Duration } \\
\text { compulsor } \\
\text { y school }\end{array}$ & $\begin{array}{l}\text { Beginning } \\
\text { age of } \\
\text { comp. } \\
\text { education }\end{array}$ & $\begin{array}{l}\text { Leaving } \\
\text { age of } \\
\text { comp. } \\
\text { education }\end{array}$ & $\begin{array}{c}\text { Primary } \\
\text { teacher } \\
\text { qualificati } \\
\text { on }\end{array}$ & $\begin{array}{c}\text { Secondar } \\
\text { y teacher } \\
\text { qualificati } \\
\text { on }\end{array}$ & $\begin{array}{l}\text { Tracking } \\
\text { age }\end{array}$ & $\begin{array}{l}\text { Standardi } \\
\text { sed tests } \\
\text { (for career } \\
\text { adv.) }\end{array}$ & $\begin{array}{l}\text { Standardi } \\
\text { sed tests } \\
\text { (for other } \\
\text { purp.) }\end{array}$ & $\begin{array}{l}\text { School } \\
\text { evaluation }\end{array}$ & $\begin{array}{l}\text { School } \\
\text { autonomy }\end{array}$ & $\begin{array}{l}\text { Teacher } \\
\text { autonomy }\end{array}$ & $\begin{array}{l}\text { Selectivity } \\
\text { in } \\
\text { university } \\
\text { accesst }\end{array}$ & $\begin{array}{c}\text { Expansion } \\
\text { of } \\
\text { university } \\
\text { access }\end{array}$ & $\begin{array}{c}\text { Increase } \\
\text { grant } \\
\text { size† }\end{array}$ & $\begin{array}{c}\text { Loan to } \\
\text { grant } \\
\text { componen } \\
\mathrm{t} \dagger\end{array}$ & $\begin{array}{c}\text { Interest } \\
\text { rate† }\end{array}$ & $\begin{array}{c}\text { Index of } \\
\text { university } \\
\text { autonomy } \\
\quad \neq\end{array}$ \\
\hline Pre-primary expansion & 1 & & & & & & & & & & & & & & & & & & \\
\hline Duration compulsory school & $0.3996 *$ & $0.3533^{*}$ & 1 & & & & & & & & & & & & & & & & \\
\hline Beginning age of comp. education & $0.1088^{\star}$ & $0.0630^{\star}$ & $-0.4678^{\star}$ & 1 & & & & & & & & & & & & & & & \\
\hline Leaving age of comp. education & $0.5010^{\star}$ & $0.4277^{*}$ & $0.9139^{\star}$ & $-0.0687^{*}$ & 1 & & & & & & & & & & & & & & \\
\hline Primary teacher qualification & $0.5433^{*}$ & $0.5627^{*}$ & $0.4965^{\star}$ & $-0.0963^{*}$ & $0.5162^{\star}$ & 1 & & & & & & & & & & & & & \\
\hline Tracking age & $0.3555^{*}$ & $0.3914^{*}$ & $0.2019^{\star}$ & $0.3184^{*}$ & $0.3741^{*}$ & $0.2722^{*}$ & $0.1969^{\star}$ & 1 & & & & & & & & & & & \\
\hline Standardised tests (for career adv.) & -0.0031 & $0.1210^{*}$ & $0.2416^{*}$ & $-0.1060^{*}$ & $0.2240^{*}$ & 0.0395 & $0.1404^{\star}$ & 0.0107 & 1 & & & & & & & & & & \\
\hline Standardised tests (for other purp.) & $0.1238^{\star}$ & $0.2271^{\star}$ & $0.3308^{\star}$ & $-0.1827^{\star}$ & $0.2894^{\star}$ & $0.3514^{\star}$ & $0.1664^{\star}$ & $0.1580^{\star}$ & $0.2848^{\star}$ & 1 & & & & & & & & & \\
\hline School evaluation & $0.3582^{\star}$ & $0.2816^{*}$ & $0.4103^{\star}$ & $-0.2384^{*}$ & $0.3536^{*}$ & $0.3986^{*}$ & $0.4209^{\star}$ & 0.0249 & $0.3361^{*}$ & $0.3520^{*}$ & 1 & & & & & & & & \\
\hline School autonomy & $0.3288^{\star}$ & $0.3317^{*}$ & $0.4282^{\star}$ & $-0.2246^{\star}$ & $0.3802^{\star}$ & $0.4199^{\star}$ & $0.4483^{*}$ & $0.1777^{*}$ & $0.2551^{\star}$ & $0.2884^{\star}$ & $0.5884^{\star}$ & 1 & & & & & & & \\
\hline Teacher autonomy & $0.1173^{*}$ & $0.1364^{*}$ & $0.2915^{*}$ & $-0.2628^{\star}$ & $0.2083^{*}$ & $0.2294^{*}$ & $0.2443^{\star}$ & 0.0091 & $0.2602^{\star}$ & $0.1637^{*}$ & $0.3768^{\star}$ & $0.5998^{\star}$ & 1 & & & & & & \\
\hline Selectivity in university access $\dagger$ & $0.1663^{*}$ & $0.3169^{*}$ & $0.3691^{*}$ & $-0.0811^{*}$ & $0.3936^{*}$ & $0.2023^{*}$ & $0.1388^{*}$ & $0.2753^{\star}$ & $0.3627^{\star}$ & $0.2712^{\star}$ & $0.2035^{\star}$ & $0.0574^{\star}$ & $0.0579^{\star}$ & 1 & & & & & \\
\hline Expansion of university access & $0.4646^{*}$ & $0.4040^{*}$ & $0.5096^{\star}$ & $-0.1788^{\star}$ & $0.4931^{*}$ & $0.5864^{*}$ & $0.5549^{*}$ & $0.3161^{\star}$ & $0.2030^{*}$ & $0.2583^{\star}$ & $0.4435^{\star}$ & $0.5164^{\star}$ & $0.2653^{\star}$ & $0.3376^{\star}$ & 1 & & & & \\
\hline Increase grant size† & $0.3097^{\star}$ & $0.1430^{\star}$ & $0.0934^{*}$ & -0.0047 & $0.1056^{\star}$ & $0.2463^{*}$ & $0.2555^{\star}$ & $0.1130^{\star}$ & $0.1125^{\star}$ & $0.2380^{\star}$ & $0.3136^{\star}$ & $0.2419^{\star}$ & $0.0595^{\star}$ & $0.1812^{\star}$ & $0.2145^{\star}$ & 1 & & & \\
\hline Loan to grant component $\dagger$ & 0.0328 & 0.0448 & $0.1516^{*}$ & $0.1630^{*}$ & $0.2361^{*}$ & $0.1703^{*}$ & -0.0351 & $0.3214^{\star}$ & $0.1924^{*}$ & 0.0154 & -0.036 & $0.1095^{\star}$ & $0.1490^{\star}$ & $0.3761^{\star}$ & $0.1457^{\star}$ & $0.0700^{\star}$ & 1 & & \\
\hline Index of university autonomy $\ddagger$ & $0.4435^{*}$ & $0.4489^{*}$ & $0.5323^{*}$ & $-0.1969^{\star}$ & $0.5378^{*}$ & $0.5582^{\star}$ & $0.5003^{*}$ & $0.2807^{*}$ & $0.3581^{*}$ & $0.6385^{*}$ & $0.4971^{*}$ & $0.4353^{*}$ & $0.1491^{\star}$ & $0.5328^{\star}$ & $0.6311^{\star}$ & $0.3462^{\star}$ & $0.1750^{\star}$ & 0.0217 & 1 \\
\hline
\end{tabular}




\subsection{Microdata on educational attainment}

Data on individual school attainment and background characteristics come from four international surveys: the European Social Survey $(E S S)^{19}$, European Union Statistics on Income and Living Conditions (EUSILC) ${ }^{20}$, International Adult Literacy Survey $(I A L S)^{21}$, and International Social Survey Programme (ISSP) ${ }^{22}$. Not all countries are covered in all the four surveys; for a list of the specific countries included in every survey, see table B1 in Appendix B.

Each survey contains information on individuals' education and background characteristics, such as gender, age, parents' education and occupation. To quantify educational attainment, we use an indicator of the duration of formal schooling, measured by the number of actual (full-time equivalent) years of education completed. The main advantage of this variable is that years of schooling can be easily computed and compared across countries, unlike other measures capturing the qualifications achieved that depend on the specific institutional structure of the different educational systems and are therefore hardly comparable in a cross-country setting. Moreover, the number of years of education completed is a continuous-like variable that allows to generate inequality indices and to investigate the shape of its distribution.

In order to maximise the number of observations available per birth year, we create our final dataset by pooling all the surveys' waves together ${ }^{23}$ and creating a pseudo panel where the time dimension is given by birth cohorts. We implicitly assume that investment in education ends when adulthood is reached, and therefore formal education remains unchanged over the life cycle of every individual. We can therefore exploit the variation in educational outcomes of different cohorts across countries to identify the effect of the characteristics of the school design. We augment individual level data with the variables on school systems that we have constructed by matching each individual to the institutional environment that her cohort faced when attending each school grade (see column 3 in table 2 ).

Assuming that formal educational attainment does not change after age 25 we restrict the sample to individuals aged more than 25 , in order to minimise the number of people who did not

\footnotetext{
${ }^{19}$ ESS is biennial survey that covers over 30 mostly European countries and provides detailed information on individual attitudes, beliefs, and behaviour collected from nationally representative population samples. It consists of repeated cross-sections initiated in 2002/2003 ( $1^{\text {st }}$ round) and then carried on in 2004/2005 ( $2^{\text {nd }}$ round), 2006/2007 ( $3^{\text {rd }}$ round) and $2008 / 2009$ ( $4^{\text {th }}$ round). The survey mainly focuses on people's attitudes and values, but it also contains several variables capturing the social background of respondents as well as their partners and parents. For more information, see http://www.europeansocialsurvey.org)

${ }^{20}$ EUSILC is a collection of comparable multidimensional microdata covering EU countries plus Iceland and Norway. EUSILC is a project developed by EUROSTAT, run yearly since 2004 and including both cross-section and longitudinal surveys. For more information, see http://epp.eurostat.ec.europa.eu/portal/page/portal/microdata/eu silc

${ }^{21}$ IALS is a survey collecting information on adult literacy in representative samples for some OECD countries. It was implemented in different years - 1994, 1996, 1998 - for different countries using a common questionnaire. The central element of the survey is the direct assessment of the literacy skills of respondents, but the background questionnaire also includes detailed information on individual socio-demographic characteristics. For more information, see http://www.statcan.gc.ca/dli-ild/data-donnees/ftp/ials-eiaa-eng.htm)

${ }^{22}$ ISSP is a continuing annual programme of cross-national collaboration on surveys covering a wide range of topics. Data collection is annual, ranging from 1985 to 2010, covering 26 countries, most of which are surveyed only in a subset of years. For more information, see http://www.issp.org/index.php

${ }^{23}$ More specifically, for ESS we pooled all the four waves; for ISSP we pooled the 1991, 1992, 1993 and 1999 waves that are the only waves containing information on parental background. For EUSILC information on parental background was only available in a special 2005 module, which forced us to use this wave only. For IALS, we only have one wave available.
} 
complete their study at the time of the survey (see also Brunello, Fort and Weber, 2009). As a consequence, the oldest cohort of individuals included in our sample was born in $1926,{ }^{24}$ while the youngest one includes individuals born in 1985. We also drop individuals reporting an amount of education exceeding 25 years of schooling, assuming that this is the highest reasonable duration of a complete educational career, starting at 5-6 years of age and ending with a Ph.D. and those additional years of education do not reflect real improvements but either misreported data or repeated years. Finally, for each country we only keep individuals who live in their country of birth, thus excluding foreign born people ${ }^{25}$. In this way, we minimize the risk of assigning to individuals a false educational system. Table 5 reports summary statistics of the individual variables included in the analysis and it can be noticed that the four datasets are rather consistent.

Table 5: Descriptive statistics - ESS, EUSILC, IALS, ISSP

\begin{tabular}{|c|c|c|c|c|c|c|c|c|c|c|}
\hline & Obs & Mean & $\begin{array}{l}\text { Std. } \\
\text { Dev. }\end{array}$ & Min & Max & Obs & Mean & $\begin{array}{l}\text { Std. } \\
\text { Dev. }\end{array}$ & Min & Max \\
\hline & \multicolumn{5}{|c|}{ ESS } & \multicolumn{5}{|c|}{ EUSILC } \\
\hline Birth year & 109415 & 1955 & 14.83 & 1926 & 1985 & 159895 & 1960 & 11.14 & 1939 & 1980 \\
\hline Age & 109415 & 50 & 15 & 25 & 84 & 159895 & 45 & 11.14 & 25 & 66 \\
\hline Female & 109415 & 0.53 & 0.50 & 0 & 1 & 159895 & 0.52 & 0.50 & 0 & 1 \\
\hline Years of education & 109415 & 12 & 4 & 0 & 25 & 159895 & 12.51 & 4.46 & 0 & 25 \\
\hline \multicolumn{11}{|c|}{ Highest qualification achieved } \\
\hline Primary education or below & 109097 & 0.15 & 0.36 & 0 & 1 & 159786 & 0.15 & 0.36 & 0 & 1 \\
\hline Lower secondary education & 109097 & 0.19 & 0.39 & 0 & 1 & 159786 & 0.14 & 0.35 & 0 & 1 \\
\hline Upper secondary education & 109097 & 0.38 & 0.49 & 0 & 1 & 159786 & 0.45 & 0.50 & 0 & 1 \\
\hline Tertiary education & 109097 & 0.28 & 0.45 & 0 & 1 & 159786 & 0.25 & 0.44 & 0 & 1 \\
\hline \multicolumn{11}{|c|}{ Parental highest qualification achieved } \\
\hline Primary education or below & 109415 & 0.35 & 0.48 & 0 & 1 & 159895 & 0.48 & 0.50 & 0 & 1 \\
\hline Lower secondary education & 109415 & 0.22 & 0.41 & 0 & 1 & 159895 & 0.17 & 0.38 & 0 & 1 \\
\hline Upper secondary education & 109415 & 0.28 & 0.45 & 0 & 1 & 159895 & 0.24 & 0.43 & 0 & 1 \\
\hline Tertiary education & 109415 & 0.15 & 0.36 & 0 & 1 & 159895 & 0.11 & 0.31 & 0 & 1 \\
\hline & \multicolumn{5}{|c|}{ IALS } & \multicolumn{5}{|c|}{ ISSP } \\
\hline Birth year & 31592 & 1953 & 11 & 1926 & 1973 & 28200 & 1949 & 13 & 1926 & 1974 \\
\hline Age & 31592 & 43 & 11 & 25 & 68 & 28200 & 45 & 13 & 25 & 73 \\
\hline Female & 31592 & 0.54 & 0.50 & 0 & 1 & 28200 & 0.52 & 0.50 & 0 & 1 \\
\hline Years of education & 31592 & 12.04 & 3.49 & 0 & 25 & 28200 & 11.28 & 3.91 & 0 & 25 \\
\hline \multicolumn{11}{|c|}{ Highest qualification achieved } \\
\hline Primary education or below & 31308 & 0.11 & 0.31 & 0 & 1 & 21543 & 0.06 & 0.24 & 0 & 1 \\
\hline Lower secondary education & 31308 & 0.29 & 0.46 & 0 & 1 & 21543 & 0.48 & 0.50 & 0 & 1 \\
\hline Upper secondary education & 31308 & 0.35 & 0.48 & 0 & 1 & 21543 & 0.32 & 0.47 & 0 & 1 \\
\hline Tertiary education & 31308 & 0.25 & 0.43 & 0 & 1 & 21543 & 0.14 & 0.34 & 0 & 1 \\
\hline \multicolumn{11}{|c|}{ Parental highest qualification achieved } \\
\hline Primary education or below & 31592 & 0.33 & 0.47 & 0 & 1 & 28200 & 0.20 & 0.40 & 0 & 1 \\
\hline Lower secondary education & 31592 & 0.35 & 0.48 & 0 & 1 & 28200 & 0.59 & 0.49 & 0 & 1 \\
\hline Upper secondary education & 31592 & 0.22 & 0.41 & 0 & 1 & 28200 & 0.15 & 0.35 & 0 & 1 \\
\hline Tertiary education & 31592 & 0.11 & 0.32 & 0 & 1 & 28200 & 0.07 & 0.25 & 0 & 1 \\
\hline
\end{tabular}

\footnotetext{
${ }^{24}$ Since our institutional measures start in 1929, the first individual aged 3 facing pre-primary education has to be born as earliest as 1926. The match with reforms affecting tertiary education could concern people born in 1914 and aged 15 in 1929 (and we have few of them in our dataset). However consistency would have required selecting only individuals staying in school beyond compulsory education, thus distorting the sample even further (the first distortion occurring because different life expectations by educational attainment).

${ }^{25}$ Foreign born people are about seven percent of the total in ESS, six percent in EUSILC and five percent in IALS.
} 
In order to present descriptive statistics on the distribution of the educational attainment, we have calculated measures of dispersion of educational attainment by countries and birth-cohorts. More specifically we compute the Gini concentration index (see Thomas et al., 2001; Checchi, 2004; Morrison and Murtin 2010; Földvári and Van Leeuwen 2011; see also Meschi and Scervini, 2010 for other applications of inequality measures to the educational context) and Atkinson indices with different inequality aversion parameters.

Figure 1 scatter plots the relationship between average years of education and the Gini concentration index ${ }^{26}$ calculated on the distribution of the same variable for each country, decennial age cohort and survey. Some stylised facts emerge from the observation of this figure. First, we observe a remarkable variation in educational outcomes across countries, both in terms of levels and dispersion. Second, we notice a negative relationship between average years of education and education inequality, suggesting that that the increase in school attainment occurred over the last century has been generally associated with a decline in inequality (Breen and Jonsson 2007). However, also the extent of this relationship varies across nations, possibly due to the difference in their institutional setting. Countries of late schooling (like Portugal, Italy and Spain) are characterised by the highest levels of educational inequality, while eastern countries benefited by free access to education in the communist era which translates in lower inequality. Eventually, by comparing the four survey datasets, we notice that they provide different snapshots of the national distribution, depending on the period when each survey was conducted.

Figure 1: Mean years of Education and GINI concentration index, by country and 5-years cohorts

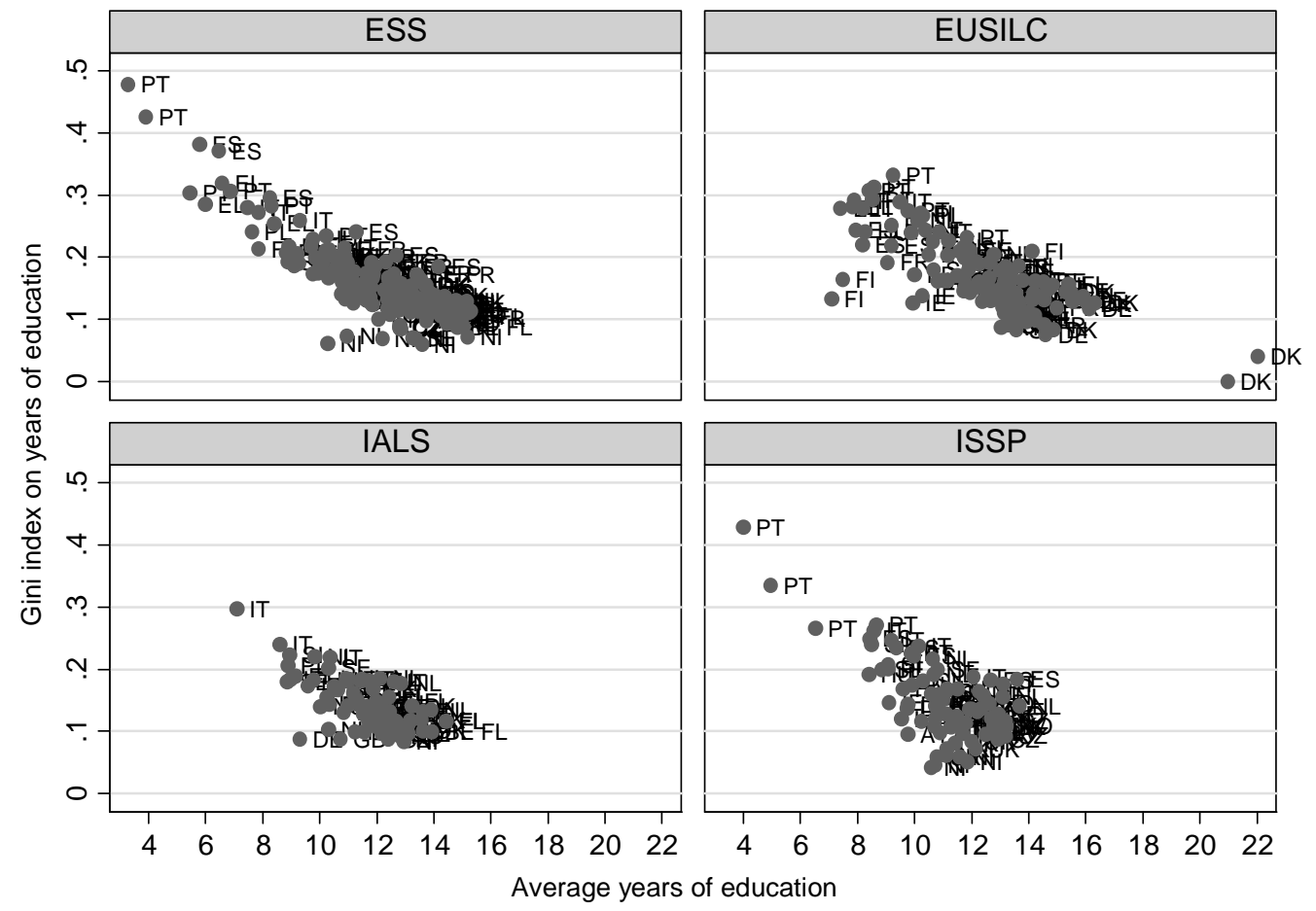

\footnotetext{
${ }^{26}$ Both Gini and Atkinson indexes are not strictly applicable to the distribution of years of education, since such an endowment cannot be redistributed interpersonally. However their use as descriptive statistics indicator is widespread and we will follow common practice.
} 
Figure 2: Educational inequality measures by country

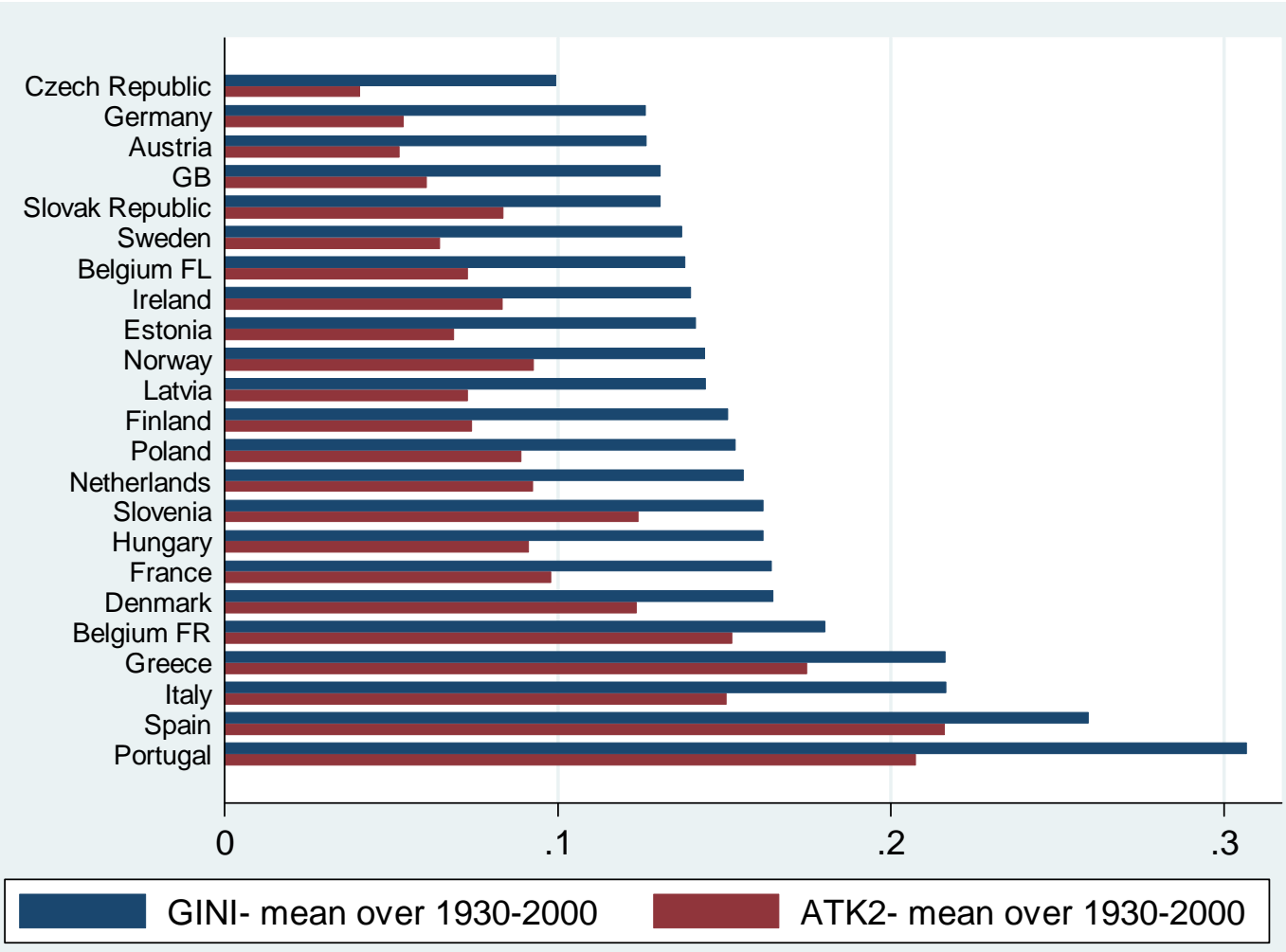

Figure 2 shows the average inequality in educational attainment (computed over the years of education) by country. Central Europe (Austria, Germany and Czech Republic) is the least unequal area (possibly a long run consequence of the early introduction of compulsory education in the Prussian empire) ${ }^{27}$, while the Mediterranean area (Portugal, Spain, Greece and Italy) is the most unequal one (a legacy of the Spanish domination?). Within the list it is impossible to rank the countries, because the confidence intervals overlap. Also notice that the Gini index is often unable to discriminate between different situations, since it assigns more weight to the centre of the frequency distribution. On the contrary, the Atkinson index (with the aversion parameter $\varepsilon=2$ ) gives relatively more weight on the lower tail of the distribution, the illiterates, and less weight at the top, the graduates. .

\section{The empirical strategy}

Our aim is to estimate a causal effect of the implementation of a set of school policies on the educational attainment of the affected population. We conduct our analysis using data for 24 countries over 70 years and we identify the effect of reforms exploiting the cross-country heterogeneity in the timing of their implementation. More specifically, we correlate changes in educational attainment in subsequent cohorts in each country with possibly occurred policy changes.

The intuition behind our identification strategy is that used in the traditional diff-in-diff approach. Suppose we had two countries $A$ and $B$ identical in any respect at time $t$. At time $t+1$ an educational reform is exogenously introduced in country $A$. The effect of this reform can be then

\footnotetext{
${ }^{27}$ The first introduction of compulsory education is attributed to Fredrick the Great, who introduced it in Prussia in 1763, followed ten years later by the Austrian Queen Mary Theresa.
} 
estimated comparing changes in mean educational attainment between year $t$ and $t+1$ in the two countries. In this setting country $B$ provides a perfect counterfactual situation for country $A$ in the absence of the reform. We adopt the same intuition in our empirical exercise, whereby we compare changes in educational attainment over time across countries that introduced reforms in the school system in different points in time. In this way, at every point in time, countries that are not affected by policy changes constitute a suitable counterfactual for the countries where a policy change occurs. This strategy provides an unbiased estimate of the causal effect of the policy under two identifying assumptions.

The first one is that changes in individual outcomes of two consecutive cohorts in different countries would have been the same in the absence of the reforms. The second assumption is that the treatment (i.e. having been exposed to a particular institutional school setting) is assigned to individuals exclusively based on the exogenously given date of birth. If the reforms were implemented based on past levels of educational attainment, then the exogeneity hypothesis would be violated. We tested this assumption by regressing the alternative reform indicators on past levels of educational attainment (5-year lags) controlling for country and cohort fixed effects. The results (shown in table B2 in Appendix B) reassure us that almost all the reforms included in the analysis are not related to changes in countries' educational attainment.

In practice, we use individual level data matched to our original dataset on school reform (as described in section 3 ) to estimate the following equation:

$$
h_{i c t}=\alpha+\beta \cdot F_{i c t}+\gamma \cdot R_{c, t+n}+\theta \cdot P B_{i c t}+\delta_{c}+\delta_{t}+\delta_{s}+\tau \cdot \delta_{c}+\varepsilon_{i c t}
$$

where $i, c$ and $t$ denote individual, country and birth cohort respectively; $h_{\text {ict }}$ is our outcome of interest (years of schooling of individual $i$ in country $c$ born in year $t$ ), $F_{i c t}$ is a gender indicator (1=female), $R_{c, t+n}$ is the institutional setting prevailing in country $c$ at time $(t+n)$ where $n$ captures the age at which the reform is supposed to affect individuals educational career ${ }^{28} ; P B_{\text {ict }}$ is a measure of family background (captured by a dichotomous variable that takes value one if at least one parent has tertiary education), $\delta_{c}, \delta_{t}$ and $\delta_{s}$ are country, birth year and survey fixed effects (controlling for all time-invariant country specific characteristics and for all the timespecific shocks that affected all countries simultaneously), and $\tau \cdot \delta_{c}$ is a country specific time trend. Finally $\varepsilon_{i c t}$ is the stochastic error term.

Since our variable of interest varies at the country $\times$ cohort rather than at the individual level, the random disturbances in the regression are likely to be correlated within groups and this causes OLS to lead to standard errors that cab be seriously biased downward (see Moulton, 1990). We therefore cluster the standard errors by country and cohort, treating them as if there were only as many observations as there are combinations of countries and cohorts in the regression (see also Brunello and Checchi, 2007). Our coefficient of interest $(\gamma)$ provides the sample average effect of each reform.

When we focus on the potential heterogeneity of the impact of the reform, we adopt different strategies. First of all, in order to test whether the same reform had a differential effect between

\footnotetext{
${ }^{28}$ In particular, $n=3$ for reforms regarding pre-primary school, $n=6, n=10$ and $n=15$ for those concerning primary, secondary and tertiary education respectively.
} 
individuals raised in culturally rich families (where at least one parent was college graduate) and those raised in culturally poor families, we interact the reform variable with measures of parental background, thus estimating the following equation:

$$
h_{i c t}=\alpha+\beta \cdot F_{i c t}+\gamma \cdot R_{c, t+n}+\theta \cdot P B_{i c t}+\varphi \cdot\left(R_{c, t+n} \times P B_{i c t}\right)+\delta_{c}+\delta_{t}+\tau \cdot \delta_{c}+\varepsilon_{i c t}
$$

The differential effect of the reform in the culturally different subgroups is given by $(\gamma)$ for culturally poor families and by $(\gamma+\varphi)$ for culturally rich families. Through the specification described above, we are able to model the relationship between our variable of interest and the conditional mean of the response variable under the assumption that the impact of the exogenous variables is invariant along the conditional distribution of the dependent variable.

We want then to move a step further and investigate whether educational reforms have differential impacts along the distribution of educational attainment. It may well be the case that some reforms do not affect the mean educational level, but only impact educational attainment of people in some points of the distribution. Think for example of the impact of changes in compulsory education laws (Brunello et al. 2009). We may expect that an increase in the minimum leaving age of compulsory education raises school attainment of those who would have left full time education at the minimum leaving age, thus affecting the bottom of the distribution only. On the other hand, other reforms such as the introduction of standardised tests, may have little impact on the bottom part of the distribution but may push achievement of those with better performance (see for example Jacob, 2005). Therefore the next step of our empirical analysis is to estimate the impact of each reform on different percentiles of years of education distribution.

More specifically, we group individual-level observations by country, cohort and survey and then we compute for each cell (countryxcohortxsurvey) the value of different percentiles of the dependent variable distribution ${ }^{29}$.

If $h_{p c t}$ denotes the $p^{\text {th }}$ percentile of the individual distribution of attainment in country $c$ for cohort $t$, then we estimate the following equation, where $p=(10,20,30,40,50,60,70,80,90)$ and $\delta_{c}, \delta_{t}, \delta_{s}$ are respectively country, cohort and survey fixed effects.

$$
h_{p c t}=\alpha_{p}+\gamma_{p} \cdot R_{c, t+n}+\delta_{t}+\delta_{c}+\delta_{s}+\varepsilon_{p c t}
$$

The vector $\gamma_{p}$ will provide the differential impact of each reform on the unconditional distribution of attainment, thus allowing to evaluate whether and to what extent the policy had entailed some distributional effects. When the reform impacts more on the bottom tail, we expect a reduction in inequality, while the reverse case occurs when impacting on the upper tail (Freeman et al. 2010).

Finally, in the same vein, we estimate a new set of regressions where the dependent variable is a synthetic index of dispersion (either the Gini index or the Atkinson index) of the years of education variable, calculated for each country, cohort and survey. In particular, for each cohort $t$ in country $c$ and survey $s$, we run the following regression:

$$
\text { Ineq }_{c t s}=\alpha+\beta \cdot \bar{h}_{c t s}+\gamma \cdot R_{c, t+n}+\theta \cdot \overline{P B}_{c t s}+\varphi \cdot \bar{F}_{c t s}+\delta_{t}+\delta_{c}+\delta_{s}+\varepsilon_{c t}
$$

\footnotetext{
${ }^{29}$ We choose this strategy instead of the more appealing one of estimating quantile regressions, because country and year fixed effect would have not remained constant over the quantiles.
} 
where Ineq $_{c t s}$ is the inequality outcome of interest (either the Gini index or the Atkinson index) for country $c$ and cohort $t$ in survey $s, \bar{h}_{c t s}$ is the average years of education of the same cohort, $R_{c, t+n}$ is the reform measure associated to cohort $t$ in country $c, \overline{P B}_{c t s}$ is the fraction of individuals with at least one parent with tertiary education in a given cohort, $\bar{F}_{c t s}$ is the fraction of women in the same cohort, and $\delta_{c}, \delta_{t}, \delta_{s}$ are respectively country, cohort and survey fixed effects. In order to account for the different sample sizes underlying inequality indices in each country $\times$ cohort $\times$ survey group, we weight the variables using the number of observations used to compute inequality indices in each cell.

\section{Results}

\subsection{Reforms in school institutions and average school attainment}

In table 6 we present the estimation of equation (1) which shows the sample average effect of different reforms. Before going to the effects of the reform, let us recall that being born in a family where at least one parent holds a college degree is associated to almost three additional years of schooling; there are obviously a variety of reasons why this may occur (financial resources, cultural resources, parental expectations, even genetics), but we do not have sufficient information in our dataset to discriminate among these alternatives. Being woman corresponds to an average disadvantage of $1 / 3$ of a year of schooling (not shown in the table). We introduce each reform separately, in order to avoid the risk of multicollinearity among the reform variables. Going back to theoretical expectation discussed in section 2, all reforms inspired by principles of universalism, quality assurance and accountability should produce an increase in the average educational attainment, whereas reforms intended to increase selectivity may exhibit ambiguous effects: on one side, by creating fiercer competition to obtain better results and/or to enter better schools, heavier selection elicits more effort and raises potential achievement; on the other side, it may discourage marginal individuals, or even prevent them from achieving (as in the case of quotas), thus reducing attainment.

Going to discuss each reform in turn, from table 6 we identify the following findings:

i) Consistently with previous findings in the literature (for example Cunha et al. 2006, Cunha and Heckman 2007), reforms expanding the access to pre-primary education seem to be associated to an increase in average educational attainment (column 1). Consistently, we observe that the later is the starting age of compulsory school (column 4) the lower is the successive attainment, suggesting that lowering the beginning age of compulsory education is an effective tool to increase educational attainment. This result captures also the effect of the introduction of compulsory pre primary education which translates into earlier entry in the school system.

ii) as expected, compulsory education favours education achievement (column 3), mostly through retaining students in schools al later stages (column 5 - confirming Brunello et al. 2009).

iii) while we expected reforms affecting teacher recruiting being positively correlated with rising educational attainment (Hanushek 2010), our results show a counterintuitive negative effect of teacher qualification requirements in pre-primary school (column 2) and no impact in primary schools (column 6). In contrast, an increase in teacher qualification in secondary schools seems to be effective in promoting higher educational attainment (column 7). Taken at face value, these 
results suggest that teacher qualification becomes more and more important the further one proceeds in the educational ladder.

iv) tracked secondary school systems lower school performance through reduced competence acquisition (Hanushek and Woessmann 2006). Although our estimates exhibit the expected sign, the positive association between the age at which students are sorted into different tracks and average educational attainment is not statistically significant ${ }^{30}$ (column 8 ).

$v$ ) the introduction of standardised tests does not have a univocal impact on educational choices. The introduction of standardised tests aimed at guiding career advancement (column 9) is associated to a reduction in average educational attainment, implying that students would be discouraged by lower test scores in proceeding further in education. On the other hand, standardised tests introduced for other reasons, such as school evaluation (column 10), seem to foster educational attainment (possibly through improved school management under accountability systems). However, we don't find any significant effect of the reforms aimed at make school more accountable, introducing different forms of school evaluation (column 11). vi) no clear conclusions can be drawn for reforms school autonomy (column 12) and teacher autonomy (column 13 - see also Woessmann et al. 2009) due to the lack of statistical significance. In contrast, a composite measure for different dimension of university autonomy obtains a negative and significant sign (column 19). This is not surprising, because the secondary school level has typically a mission of expanding school participation, and it pursues it also by adapting to the local environment. On the contrary, tertiary education institutions can make use of greater autonomy to improve their competitiveness in the higher education market, not necessarily leading to larger student attendance.

vii) finally policies to foster tertiary education show positive association with average educational attainment, as visible from sign and significance of variables related to the expansion of educational supply (column 15). ${ }^{31}$ In terms of cost reduction, the increase in the availability of grant financing for university students (column 16) is positively associated to average years of education, although the point estimate is not statistically significant, while higher proportion of loan to grant component (column 17) and higher interest rates charged to the student for applied to loan (column 18) decrease average educational attainment.

We may summarise previous results by saying that universalistic policies (expansion of compulsory education, de-tracking, opening access to universities, subsidising university attendance) raise the average educational attainment of the corresponding populations, while policies targeted to quality improvements (either through higher selectivity on access or through increased accountability of educational institutions) tend to reduce it.

However these are average results, which should be qualified by partitioning the populations into more homogenous subgroups. A first way to accomplish this goal is to distinguish between children from "culturally rich" and "culturally poor" families, by considering whether households include at least one parent with college degree. By estimating equation (2) we obtain the results reported in table 7 . With respect to previous findings we may add the following comments:

wiii) reforms have differentiated effects according to family background. In table 8 we have reported the average impact (from table 6 for ease of comparison) and the impact by family background (from table 7). We notice that in most cases reforms tend to have an attenuated

\footnotetext{
${ }^{30}$ The point estimate turns out to be positive and statistically significant when we do not include a country specific time trend.

${ }^{31}$ Remember that "expansion of university access" collect information about a combination of alternative measures, like open access from vocational high schools, geographical expansion of universities and creation of polytechnic institutions providing non-university vocational higher education (see table 2).
} 
impact for children from culturally rich environments, when compared to their counterparts from culturally poor families. Take for example the case of expansion of pre-primary education (column 1): it has a positive average effect in the population, which is driven by the large fraction of population with parents without college education (corresponding to $88 \%$ of the sample). For the other group coming from advantaged backgrounds, the reform has a negative impact, which reduces the advantage they obtain from the family. Seen in this perspective, the reform has an equalising effect. This is the case for pre-primary education (columns 1), compulsory education (columns 3 and 5 - negligible but contradictory results in the case of starting age for compulsory, which now has positive impact on both groups), primary and secondary school teacher qualification (columns 6 and 7), tracking age (column 8 - negligible impact on both groups of children), school evaluation and autonomy (columns 11 and 12), expansion of access to universities (column 15) and financial support in college through grant size (column 16)

ix) when reforms represent an obstacle to education expansion (as in the cases of pre-primary teacher qualifications - column 2 , teacher autonomy - column 13 , selectivity in university access - colum14, university autonomy - column 19), this effect is weaker in the case of children from culturally poor environments (possibly because their parents are less capable to choose, and therefore less reactive to perceived school quality). Even when reforms enhanced student testing, those who seem more negatively affected by the introduction of these measures are the children from college-educated parents (column 9 - however the opposite occurs in the case of testing for accountability reasons - column 10). Eventually, when considering cost of financing investment in tertiary education, those mostly hampered by different combinations of loans vs. grants and/or by higher interest rates are students from advantaged backgrounds (columns 17 and 18).

An alternative strategy to characterise educational reforms is to look at their average impact on intergenerational persistence in educational attainment. To see this, we have estimated this elasticity in each cell country $\times$ cohort $\times$ survey, and then regressed the estimated coefficients on the corresponding reform variable adding country and cohort fixed effects ${ }^{32}$. Results are reported in table 9, where we recognize that there is a group of reforms that clearly reduce intergenerational persistence (or, equivalently, increases the equality of opportunities, making the educational system more equitable): this is the case of compulsory education (especially raising the leaving age - columns 3 and 5), secondary school teacher qualification (column 7), detracking (column 8), expansion of university access (column 16), increased grant size (column 17) and increased school accountability (column 12). On the contrary increasing pre-primary teacher qualification, introducing standardized test for career advancement purposes or increasing teacher autonomy (columns 2, 9 and 14 respectively) is correlated with a higher intergenerational persistence in educational attainments.

\footnotetext{
${ }^{32}$ The regressions are weighted using the inverse of the standard errors of the coefficients estimated in the first step.
} 
Table 6: Reforms and educational attainment

\begin{tabular}{|c|c|c|c|c|c|c|c|c|c|c|}
\hline & $\begin{array}{c}\text { Pre- } \\
\text { primary } \\
\text { expansion }\end{array}$ & $\begin{array}{l}\text { Pre-primary } \\
\text { teacher } \\
\text { qualification }\end{array}$ & $\begin{array}{l}\text { Duration } \\
\text { compulsory } \\
\text { school }\end{array}$ & $\begin{array}{l}\text { Beginning } \\
\text { age comp } \\
\text { education }\end{array}$ & $\begin{array}{l}\text { Leaving } \\
\text { age comp } \\
\text { education }\end{array}$ & $\begin{array}{c}\text { Primary } \\
\text { teacher } \\
\text { qualification }\end{array}$ & $\begin{array}{l}\text { Secondary } \\
\text { teacher } \\
\text { qualification }\end{array}$ & $\begin{array}{l}\text { Tracking } \\
\text { age }\end{array}$ & $\begin{array}{l}\text { Standardised } \\
\text { tests (for } \\
\text { career adv.) }\end{array}$ & $\begin{array}{c}\text { Standardised } \\
\text { tests (for } \\
\text { other } \\
\text { purposes) }\end{array}$ \\
\hline & (1) & (2) & (3) & (4) & (5) & (6) & $(7)$ & (8) & (9) & (10) \\
\hline \multirow[t]{2}{*}{ Graduate parent } & $3.011^{\star \star \star}$ & $3.012^{\star \star \star}$ & $3.010^{\star \star *}$ & $3.012^{\star \star \star}$ & $3.011^{\star \star \star}$ & $3.012^{\star \star \star}$ & $3.011^{\star \star \star}$ & $3.011^{\star \star \star}$ & $3.013^{\star \star \star}$ & $3.011^{\star \star \star}$ \\
\hline & [0.042] & [0.042] & [0.042] & [0.042] & [0.042] & [0.042] & [0.042] & [0.042] & [0.042] & [0.042] \\
\hline \multirow[t]{2}{*}{ Reform } & $0.132^{\star \star \star}$ & $-0.191^{\star \star \star x}$ & $0.061^{\star \star x}$ & $-0.607^{\star \star \star}$ & $0.048^{\star \star x}$ & -0.000 & $0.169^{\star \star \star}$ & 0.012 & $-0.432^{\star \star \star}$ & $0.429^{\star \star x}$ \\
\hline & [0.049] & [0.044] & [0.014] & [0.117] & [0.014] & [0.054] & [0.048] & [0.010] & [0.076] & [0.090] \\
\hline Obs. & 329102 & 329102 & 329102 & 329102 & 329102 & 329102 & 329102 & 329102 & 329102 & 329102 \\
\hline $\mathrm{R}^{2}$ & 0.258 & 0.258 & 0.258 & 0.258 & 0.258 & 0.258 & 0.258 & 0.258 & 0.258 & 0.258 \\
\hline \multirow[t]{3}{*}{ Countries } & 24 & 24 & 24 & 24 & 24 & 24 & 24 & 24 & 24 & 24 \\
\hline & $\begin{array}{l}\text { School } \\
\text { evaluation }\end{array}$ & $\begin{array}{l}\text { School } \\
\text { autonomy }\end{array}$ & $\begin{array}{l}\text { Teacher } \\
\text { autonomy }\end{array}$ & $\begin{array}{c}\text { Selectivity } \\
\text { university } \\
\text { access }\end{array}$ & $\begin{array}{c}\text { Expansion } \\
\text { university } \\
\text { access }\end{array}$ & $\begin{array}{l}\text { Increase } \\
\text { grant size }\end{array}$ & $\begin{array}{l}\text { Loan to } \\
\text { grant } \\
\text { component } \\
\end{array}$ & $\begin{array}{l}\text { Interest } \\
\text { rate }\end{array}$ & $\begin{array}{l}\text { Index of } \\
\text { university } \\
\text { autonomy }\end{array}$ & \\
\hline & (11) & (12) & (13) & (14) & (15) & (16) & (17) & (18) & (19) & \\
\hline \multirow[t]{2}{*}{ Graduate parent } & $3.012^{\star \star \star *}$ & $3.012^{\star \star \star}$ & $3.012^{\star \star \star *}$ & $3.019^{\star \star \star}$ & $3.011^{\star \star \star}$ & $3.019^{\star \star *}$ & $3.022^{\star \star \star *}$ & $3.020^{\star \star \star}$ & $3.008^{\star \star \star}$ & \\
\hline & [0.042] & [0.042] & [0.042] & [0.055] & [0.042] & [0.055] & [0.055] & [0.055] & [0.051] & \\
\hline \multirow[t]{2}{*}{ Reform } & 0.017 & 0.133 & -0.021 & $-0.176^{\star \star}$ & $0.171^{\star \star \star}$ & 0.235 & $-0.830^{\star \star \star}$ & $-1.010^{\star \star \star}$ & $-0.209^{\star \star \star}$ & \\
\hline & [0.108] & [0.087] & [0.063] & [0.077] & [0.050] & {$[0.147]$} & [0.196] & [0.340] & [0.095] & \\
\hline Obs. & 329102 & 329102 & 329102 & 224969 & 329102 & 224969 & 224969 & 224969 & 240482 & \\
\hline $\mathrm{R}^{2}$ & 0.258 & 0.258 & 0.258 & 0.287 & 0.258 & 0.287 & 0.287 & 0.287 & 0.283 & \\
\hline Countries & 24 & 24 & 24 & $17^{\#}$ & 24 & $17^{\#}$ & $17^{\#}$ & $17^{\#}$ & $18^{\# \#}$ & \\
\hline
\end{tabular}


Table 7: Reforms and educational attainment - interaction between reforms and parental background

\begin{tabular}{|c|c|c|c|c|c|c|c|c|c|c|}
\hline & $\begin{array}{c}\text { Pre- } \\
\text { primary } \\
\text { expansion }\end{array}$ & $\begin{array}{l}\text { Pre-primary } \\
\text { teacher } \\
\text { qualification }\end{array}$ & $\begin{array}{l}\text { Duration } \\
\text { compulsory } \\
\text { school }\end{array}$ & $\begin{array}{l}\text { Beginning } \\
\text { age comp } \\
\text { education }\end{array}$ & $\begin{array}{l}\text { Leaving } \\
\text { age comp } \\
\text { education }\end{array}$ & $\begin{array}{c}\text { Primary } \\
\text { teacher } \\
\text { qualification }\end{array}$ & $\begin{array}{l}\text { Secondary } \\
\text { teacher } \\
\text { qualification }\end{array}$ & $\begin{array}{l}\text { Tracking } \\
\text { age }\end{array}$ & $\begin{array}{l}\text { Standardised } \\
\text { tests (for } \\
\text { career adv.) }\end{array}$ & $\begin{array}{l}\text { Standardised } \\
\text { tests (for } \\
\text { other } \\
\text { purposes) }\end{array}$ \\
\hline & $(1)$ & (2) & (3) & (4) & (5) & (6) & $(7)$ & (8) & (9) & (10) \\
\hline Graduate parent & $\begin{array}{l}3.207^{\star \star \star} \\
{[0.056]}\end{array}$ & $3.125^{\star \star \star}$ & $6.816^{\star \star *}$ & $\begin{array}{l}2.737^{\star \star \star} \\
{[0.4191}\end{array}$ & $\begin{array}{c}10.562^{\star \star \star} \\
{[0.435}\end{array}$ & $3.478^{\star \star \star}$ & $3.319^{\star \star \star}$ & $5.129 \times *$ & $3.105^{\star \star \star *}$ & $3.073^{\star \star \star *}$ \\
\hline Reform & $\begin{array}{l}0.195^{\star \star \star} \\
{[0.050]}\end{array}$ & $\begin{array}{c}-0.123^{\star \star \star} \\
{[0.047]}\end{array}$ & $\begin{array}{l}0.111^{\star \star \star} \\
{[0.014]}\end{array}$ & $\begin{array}{l}-0.613^{\star \star \star} \\
{[0.117]}\end{array}$ & $\begin{array}{l}0.104^{\star \star \star} \\
{[0.014]}\end{array}$ & $\begin{array}{l}0.111^{\star \star} \\
{[0.056]}\end{array}$ & $\begin{array}{c}0.224^{\star \star \star} \\
{[0.050]}\end{array}$ & $\begin{array}{l}0.028^{\star \star \star} \\
{[0.010]}\end{array}$ & $\begin{array}{c}-0.295^{\star \star \star} \\
{[0.084]}\end{array}$ & $\begin{array}{c}-0.956^{\star \star \star} \\
{[0.099]}\end{array}$ \\
\hline Reform $\times$ graduate parent & $\begin{array}{c}-0.573^{\star \star \star} \\
{[0.104]}\end{array}$ & $\begin{array}{c}-0.515^{\star \star \star} \\
{[0.107]}\end{array}$ & $\begin{array}{l}-0.436^{\star \star \star} \\
{[0.024]}\end{array}$ & $\begin{array}{c}0.044 \\
{[0.065]}\end{array}$ & $\begin{array}{l}-0.503^{\star \star \star} \\
{[0.029]}\end{array}$ & $\begin{array}{c}-1.156^{\star \star \star} \\
{[0.090]}\end{array}$ & $\begin{array}{c}-0.588^{\star \star \star} \\
{[0.089]}\end{array}$ & $\begin{array}{l}-0.160^{\star \star \star} \\
{[0.021]}\end{array}$ & $\begin{array}{c}-1.089^{\star \star \star} \\
{[0.152]}\end{array}$ & $\begin{array}{l}0.635^{\star \star \star} \\
{[0.096]}\end{array}$ \\
\hline $\begin{array}{l}\text { Observations } \\
\mathrm{R}^{2}\end{array}$ & $\begin{array}{c}329102 \\
0.258\end{array}$ & $\begin{array}{c}329102 \\
0.258\end{array}$ & $\begin{array}{c}329102 \\
0.260\end{array}$ & $\begin{array}{c}329102 \\
0.258\end{array}$ & $\begin{array}{c}329102 \\
0.261\end{array}$ & $\begin{array}{c}329102 \\
0.259\end{array}$ & $\begin{array}{c}329102 \\
0.258\end{array}$ & $\begin{array}{c}329102 \\
0.259\end{array}$ & $\begin{array}{c}329102 \\
0.258\end{array}$ & $\begin{array}{c}329102 \\
0.258\end{array}$ \\
\hline Countries & 24 & 24 & 24 & 24 & 24 & 24 & 24 & 24 & 24 & 24 \\
\hline & $\begin{array}{l}\text { School } \\
\text { evaluation }\end{array}$ & $\begin{array}{l}\text { School } \\
\text { autonomy }\end{array}$ & $\begin{array}{l}\text { Teacher } \\
\text { autonomy }\end{array}$ & $\begin{array}{c}\text { Selectivity } \\
\text { university } \\
\text { access }\end{array}$ & $\begin{array}{c}\text { Expansion } \\
\text { university } \\
\text { access }\end{array}$ & $\begin{array}{l}\text { Increase } \\
\text { grant size }\end{array}$ & $\begin{array}{c}\text { Loan to } \\
\text { grant } \\
\text { component } \\
\end{array}$ & $\begin{array}{l}\text { Interest } \\
\text { rate }\end{array}$ & $\begin{array}{l}\text { Index of } \\
\text { university } \\
\text { autonomy }\end{array}$ & \\
\hline & $(11)$ & $(12)$ & (13) & (14) & (15) & $(16)$ & (17) & (18) & (19) & \\
\hline Graduate parent & $\begin{array}{l}3.032^{\star \star *} \\
{[0.042]}\end{array}$ & $\begin{array}{l}3.062^{\star \star *} \\
{[0.045]}\end{array}$ & $\begin{array}{l}3.134^{\star \star \star} \\
{[0.047]}\end{array}$ & 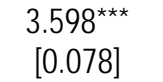 & $\begin{array}{c}3.438 \text {. } \\
{[0.058]}\end{array}$ & $\begin{array}{l}3.618^{\star \star \star} \\
{[0.165]}\end{array}$ & $\begin{array}{l}3.960^{\star \star \star} \\
{[0.077]}\end{array}$ & $\begin{array}{l}3.371 \text { «* } \\
{[0.091]}\end{array}$ & $\begin{array}{c}3.535^{\star \star \star} \\
{[0.063]}\end{array}$ & \\
\hline Reform & $\begin{array}{l}0.223^{\star \star} \\
{[0.096]}\end{array}$ & $\begin{array}{l}0.206^{\star *} \\
{[0.089]}\end{array}$ & $\begin{array}{c}0.089 \\
{[0.063]}\end{array}$ & $\begin{array}{c}0.049 \\
{[0.080]}\end{array}$ & $\begin{array}{l}0.2699^{\star \star \star} \\
{[0.051]}\end{array}$ & $\begin{array}{l}0.501^{\star \star \star} \\
{[0.143]}\end{array}$ & $\begin{array}{c}0.246 \\
{[0.194]}\end{array}$ & $\begin{array}{l}-0.643^{\star} \\
{[0.338]}\end{array}$ & $\begin{array}{c}0.123 \\
{[0.101]}\end{array}$ & \\
\hline Reform $\times$ graduate parent & $\begin{array}{c}-1.219^{\star \star \star} \\
{[0.204]}\end{array}$ & $\begin{array}{c}-0.612^{\star \star \star} \\
{[0.096]}\end{array}$ & $\begin{array}{c}-0.789 \star \star \star \\
{[0.088]}\end{array}$ & $\begin{array}{c}-1.217^{\star \star \star} \\
{[0.101]}\end{array}$ & $\begin{array}{c}-0.883^{\star \star \star} \\
{[0.104]}\end{array}$ & $\begin{array}{c}-1.127^{\star \star \star} \\
{[0.274]}\end{array}$ & $\begin{array}{c}-2.778^{\star \star \star} \\
{[0.148]}\end{array}$ & $\begin{array}{c}-1.041^{\star \star \star} \\
{[0.191]}\end{array}$ & $\begin{array}{c}-2.169^{\star \star \star} \\
{[0.142]}\end{array}$ & \\
\hline Observations & 329102 & 329102 & 329102 & 224969 & 329102 & 224969 & 224969 & 224969 & 240482 & \\
\hline $\mathrm{R}^{2}$ & 0.258 & 0.258 & 0.258 & 0.289 & 0.258 & 0.287 & 0.290 & 0.288 & 0.285 & \\
\hline Countries & 24 & 24 & 24 & 24 & $17^{\#}$ & 24 & $17^{\#}$ & $17^{\#}$ & $18^{\prime \prime \prime}$ & \\
\hline
\end{tabular}


Table 8: Point estimates of the effect of a unitary variation in the reform variables coefficients from tables 6 (average effect) and 7 (differential effects)

\begin{tabular}{|c|c|c|c|c|c|c|c|c|c|c|}
\hline & $\begin{array}{l}\text { Pre-primary } \\
\text { expansion }\end{array}$ & $\begin{array}{l}\text { Pre-primary } \\
\text { teacher } \\
\text { qualification }\end{array}$ & $\begin{array}{l}\text { Duration } \\
\text { compulsory } \\
\text { school }\end{array}$ & $\begin{array}{c}\text { Beginning age } \\
\text { comp } \\
\text { education }\end{array}$ & $\begin{array}{l}\text { Leaving age } \\
\text { comp } \\
\text { education }\end{array}$ & $\begin{array}{c}\text { Primary } \\
\text { teacher } \\
\text { qualification }\end{array}$ & $\begin{array}{l}\text { Secondary } \\
\text { teacher } \\
\text { qualification }\end{array}$ & Tracking age & $\begin{array}{l}\text { Standardised } \\
\text { tests (for } \\
\text { career adv.) }\end{array}$ & $\begin{array}{c}\text { Standardised } \\
\text { tests (for } \\
\text { other } \\
\text { purposes) }\end{array}$ \\
\hline & $(1)$ & (2) & (3) & $(4)$ & $(5)$ & $(6)$ & $(7)$ & $(8)$ & (9) & $(10)$ \\
\hline average effect & 0.132 & -0.191 & 0.061 & -0.607 & 0.048 & 0 & 0.169 & 0.012 & -0.432 & 0.429 \\
\hline parent without college & 0.20 & -0.12 & 0.11 & -0.61 & 0.10 & 0.11 & 0.22 & 0.03 & -0.30 & -0.96 \\
\hline \multirow[t]{3}{*}{ parent with college } & -0.38 & -0.64 & -0.33 & -0.57 & -0.40 & -1.05 & -0.36 & -0.13 & -1.38 & -0.32 \\
\hline & $\begin{array}{l}\text { School } \\
\text { evaluation }\end{array}$ & $\begin{array}{l}\text { School } \\
\text { autonomy }\end{array}$ & $\begin{array}{l}\text { Teacher } \\
\text { autonomy }\end{array}$ & $\begin{array}{c}\text { Selectivity } \\
\text { university } \\
\text { access }\end{array}$ & $\begin{array}{c}\text { Expansion } \\
\text { university } \\
\text { access }\end{array}$ & $\begin{array}{l}\text { Increase grant } \\
\text { size }\end{array}$ & $\begin{array}{l}\text { Loan to grant } \\
\text { component }\end{array}$ & Interest rate & $\begin{array}{l}\text { Index of } \\
\text { university } \\
\text { autonomy }\end{array}$ & \\
\hline & $(11)$ & $(12)$ & $(13)$ & $(14)$ & $(15)$ & $(16)$ & $(17)$ & $(18)$ & (19) & \\
\hline average effect & 0.017 & 0.133 & -0.021 & -0.176 & 0.171 & 0.235 & -0.83 & -1.01 & -0.209 & \\
\hline parent without college & 0.22 & 0.21 & 0.09 & 0.05 & 0.27 & 0.50 & 0.25 & -0.64 & 0.12 & \\
\hline parent with college & -1.00 & -0.41 & -0.70 & -1.17 & -0.61 & -0.63 & -2.53 & -1.68 & -2.05 & \\
\hline
\end{tabular}


Table 9: Correlation between intergenerational elasticities and reform variables

\begin{tabular}{|c|c|c|c|c|c|c|c|c|c|c|}
\hline & $\begin{array}{l}\text { Pre-primary } \\
\text { expansion }\end{array}$ & $\begin{array}{l}\text { Pre-primary } \\
\text { teacher } \\
\text { qualification }\end{array}$ & $\begin{array}{l}\text { Duration } \\
\text { compulsory } \\
\text { school }\end{array}$ & $\begin{array}{c}\text { Beginning age } \\
\text { comp } \\
\text { education }\end{array}$ & $\begin{array}{l}\text { Leaving age } \\
\text { comp } \\
\text { education }\end{array}$ & $\begin{array}{c}\text { Primary } \\
\text { teacher } \\
\text { qualification }\end{array}$ & $\begin{array}{l}\text { Secondary } \\
\text { teacher } \\
\text { qualification }\end{array}$ & Tracking age & $\begin{array}{l}\text { Standardised } \\
\text { tests (for } \\
\text { career adv.) }\end{array}$ & $\begin{array}{c}\text { Standardised } \\
\text { tests (for } \\
\text { other } \\
\text { purposes) } \\
\end{array}$ \\
\hline & (1) & (2) & (3) & (4) & (5) & (6) & (7) & (8) & (9) & (10) \\
\hline \multirow[t]{2}{*}{ Reform } & -0.093 & $0.448^{\star \star \star}$ & $-0.135^{\star \star \star}$ & 0.437 & $-0.121^{\star \star \star}$ & 0.214 & $-0.368^{\star \star}$ & $-0.109^{\star \star \star}$ & $0.560^{\star}$ & 0.002 \\
\hline & [0.192] & [0.162] & [0.038] & [0.303] & [0.036] & [0.197] & [0.163] & [0.039] & [0.325] & [0.172] \\
\hline Observations & 1362 & 1362 & 1362 & 1362 & 1362 & 1362 & 1362 & 1362 & 1362 & 1362 \\
\hline \multirow[t]{3}{*}{$\mathrm{R}^{2}$} & 0.512 & 0.514 & 0.515 & 0.513 & 0.514 & 0.512 & 0.513 & 0.516 & 0.514 & 0.512 \\
\hline & $\begin{array}{l}\text { School } \\
\text { evaluation }\end{array}$ & $\begin{array}{l}\text { School } \\
\text { autonomy }\end{array}$ & $\begin{array}{l}\text { Teacher } \\
\text { autonomy }\end{array}$ & $\begin{array}{c}\text { Selectivity } \\
\text { university } \\
\text { access }\end{array}$ & $\begin{array}{c}\text { Expansion } \\
\text { university } \\
\text { access } \\
\end{array}$ & $\begin{array}{l}\text { Increase grant } \\
\text { size }\end{array}$ & $\begin{array}{l}\text { Loan to grant } \\
\text { component }\end{array}$ & Interest rate & $\begin{array}{l}\text { Index of } \\
\text { university } \\
\text { autonomy }\end{array}$ & \\
\hline & (12) & (13) & (14) & (15) & (16) & (17) & (18) & (19) & (20) & \\
\hline \multirow[t]{2}{*}{ Reform } & $-0.584^{\star}$ & 0.114 & $0.369^{\star \star}$ & 0.098 & $-0.482^{\star \star \star}$ & $-0.838^{\star \star \star}$ & -0.398 & -0.398 & -0.136 & \\
\hline & [0.302] & [0.183] & [0.169] & [0.166] & [0.144] & [0.278] & [0.354] & [0.354] & [0.373] & \\
\hline Observations & 1362 & 1362 & 1362 & $961^{\#}$ & 1362 & $961^{\#}$ & $961^{\#}$ & $961^{\#}$ & $1020^{\# \#}$ & \\
\hline $\mathrm{R}^{2}$ & 0.513 & 0.512 & 0.513 & 0.564 & 0.515 & 0.566 & 0.564 & 0.564 & 0.554 & \\
\hline
\end{tabular}

Note: robust standard errors in brackets - statistical significance: $* * * p<0.01, * * p<0.05, * p<0.1-$ Constant, birth year, and country controls included

- \#: no reform data for Estonia, Hungary, Latvia, Poland, Slovak Rp., Slovenia and Czech Rp.;

\#\# : no reform data for Estonia, Hungary, Latvia, Poland, Slovak Rp. and Slovenia 


\subsection{Distributional effects of reforms}

An alternative strategy to investigate the potential heterogeneity of educational reforms is by estimating the impact of reforms on different percentiles of the years of education distribution (see equation (3). Figure 3 plots the estimated coefficients, with a $90 \%$ confidence interval, by deciles of the distribution of educational attainment. ${ }^{33}$ As a rule of thumb, we may say that whenever the estimated profiles in figure 3 are decreasing, inequality should be reduced by the corresponding reform, whereas the opposite situation applies for increasing profiles.

Some reforms seem targeted to low achievers: it is the case of duration of compulsory education as well as the expansion of access to tertiary education. Some other reforms are more effective in pushing up the attainment of higher achievers: this is the case of rising tracking age (which by construction affects those who choose at least secondary school or more), the increase in teachers' qualification (again at secondary level) and the enhancing of selective access to college (trough admission tests). Some other reforms contribute to make the educational attainment distribution more unequal, by creating obstacles to low achiever and/or by boosting high achievers: this is the case of delaying the start of compulsory education, reforms enhancing school or teachers' autonomy and/or introducing test based school assessment. It is less clear the relative contribution of reforms that raise teacher qualifications (at least at pre-primary and primary level), as well as reforms that introduce standardised tests at the exit of secondary schools.

However it is worth noting that a large fraction of the impact in statistically not significant over many deciles, and it is then almost impossible to predict the overall impact on the distribution of educational attainment just by looking at the slope of the estimated impacts.

Therefore, we prefer to perform a more direct test by estimating equations (4) using Atkinson index $(\varepsilon=2)$ as dependent variable. We choose this index because it is more sensitive to the bottom tail of the distribution and it accounts for the incidence of illiterate people as well as highly educated ones. The results of a regression of education inequality measure onto reform variables, controlling for gender composition, mean educational attainment and parental background are presented in table 10 . The number of observations refers to country $\times$ cohort $\times$ survey cells. Most of the previously obtained results are maintained: reforming compulsory education, detracking, improving secondary teacher qualification and expanding university access contribute to reduce educational inequality. On the contrary, introduction of standardised tests, more selective access criteria to universities and/or greater autonomy offered to teachers, schools and universities are associated to augmented inequality in years of education.

We may then characterise two types of reforms: reforms that raise the bottom tail of the endowment distribution and reforms that increase the dispersion in the upper tail of the same distribution (whatever the original asset can be: parental education, family wealth or even innate ability). We could call inclusive the first family and selective the second family of reforms.

\footnotetext{
${ }^{33}$ As we mentioned above, deciles are computed on country×cohort cells (in order to avoid the risk of having oldest people in the lowest deciles and youngest in the highest ones. The corresponding mean years of education for each decile are reported in brackets: 1(5)-2(8)-3(10)-4(11)-5(12)-6(13)-7(14)-8(15)-9(17)-10(21).
} 
Figure 3: impact of reforms and on different deciles of educational attainment - estimated coefficients (and $90 \%$ confidence intervals)

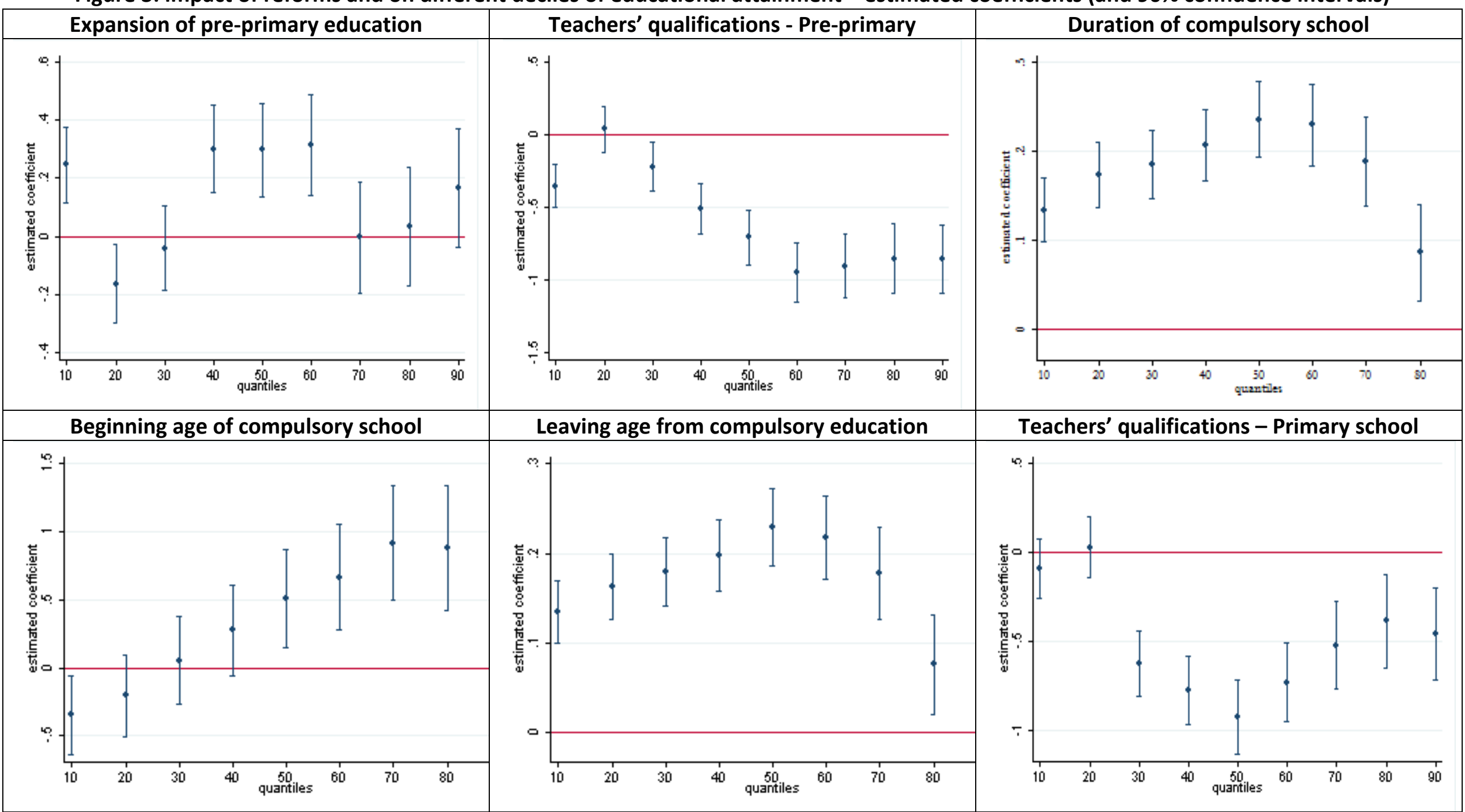




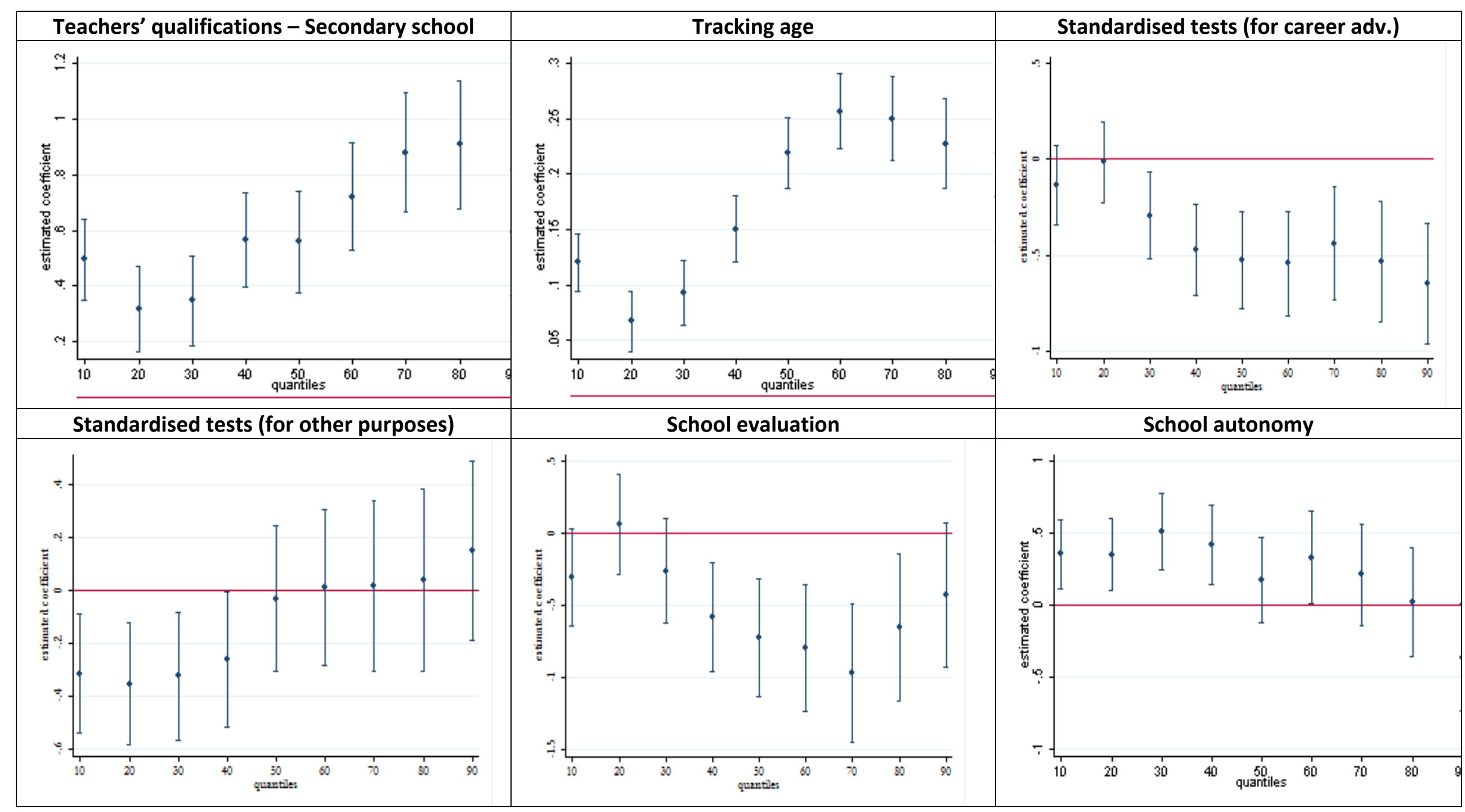




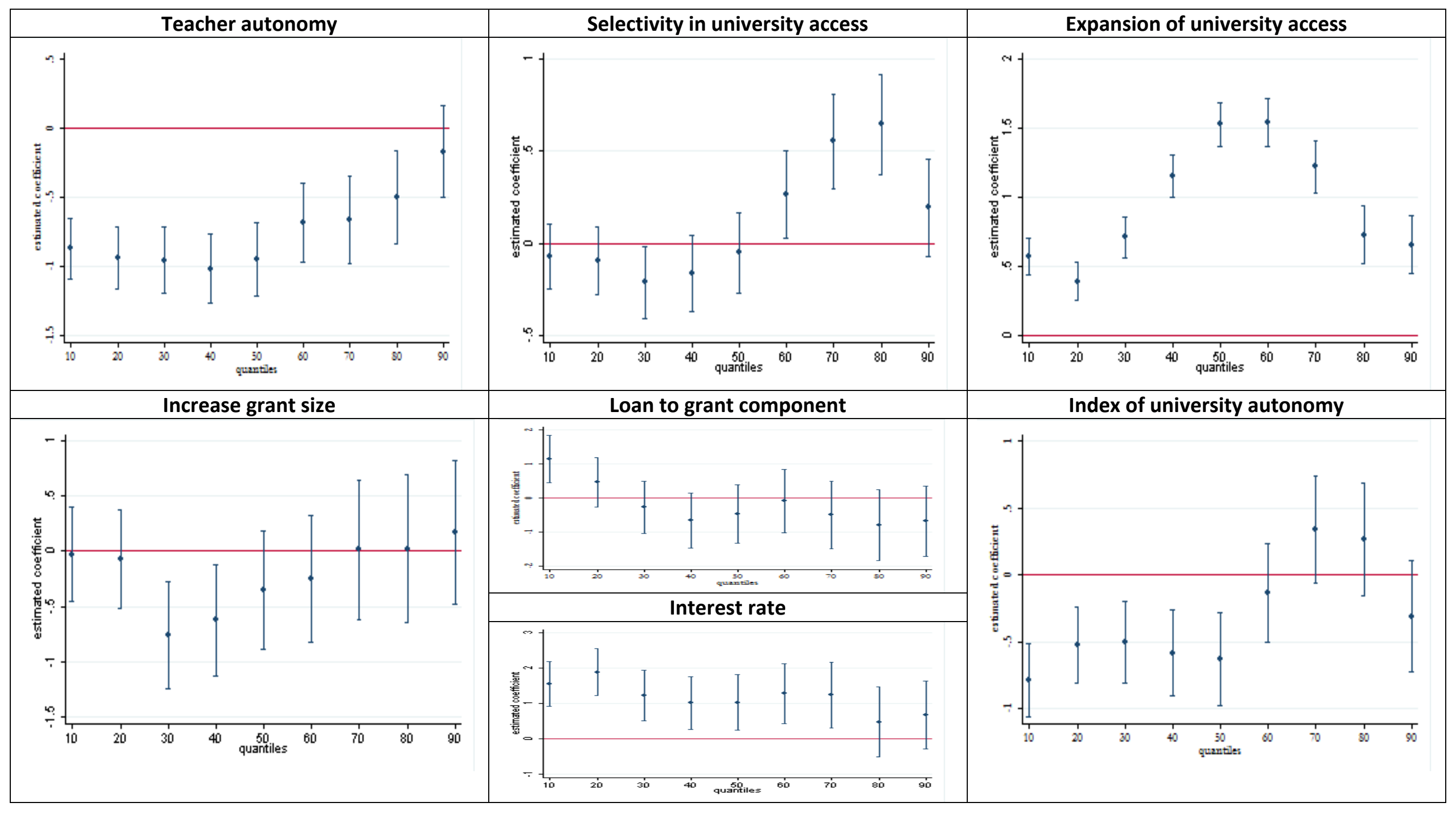


Table 10: Impact of reforms on educational inequality: Dependent variable: Atkinson index $(\varepsilon=2)$

\begin{tabular}{|c|c|c|c|c|c|c|c|c|c|c|}
\hline & $\begin{array}{l}\text { Pre-primary } \\
\text { expansion }\end{array}$ & $\begin{array}{l}\text { Pre-primary } \\
\text { teacher } \\
\text { qualific. }\end{array}$ & $\begin{array}{l}\text { Duration } \\
\text { compulsory } \\
\text { school }\end{array}$ & $\begin{array}{c}\text { Beginning age } \\
\text { comp } \\
\text { education }\end{array}$ & $\begin{array}{c}\text { Leaving age } \\
\text { comp } \\
\text { education }\end{array}$ & $\begin{array}{l}\text { Primary } \\
\text { teacher } \\
\text { qualific. }\end{array}$ & $\begin{array}{l}\text { Secondary } \\
\text { teacher } \\
\text { qualific. }\end{array}$ & Tracking age & $\begin{array}{l}\text { Standardised } \\
\text { tests (for } \\
\text { career adv.) }\end{array}$ & $\begin{array}{l}\text { Stand. tests } \\
\text { (for other } \\
\text { purposes) }\end{array}$ \\
\hline & (1) & (2) & (3) & $(4)$ & (5) & (6) & $(7)$ & (8) & (9) & (10) \\
\hline Mean years of education & $\begin{array}{c}-0.010 * * * \\
(0.001)\end{array}$ & $\begin{array}{c}-0.010 * * * \\
(0.001)\end{array}$ & $\begin{array}{c}-0.009 * * * \\
(0.001)\end{array}$ & $\begin{array}{c}-0.010 * * * \\
(0.001)\end{array}$ & $\begin{array}{c}-0.009 * * * \\
(0.001)\end{array}$ & $\begin{array}{c}-0.010 * * * \\
(0.001)\end{array}$ & $\begin{array}{c}-0.009 * * * \\
(0.001)\end{array}$ & $\begin{array}{c}-0.009 * * * \\
(0.001)\end{array}$ & $\begin{array}{c}-0.009 * * * \\
(0.001)\end{array}$ & $\begin{array}{c}-0.010 * * * \\
(0.001)\end{array}$ \\
\hline Share of people with graduate parent & $\begin{array}{c}0.061 * * * \\
(0.013)\end{array}$ & $\begin{array}{c}0.061 * * * \\
(0.013)\end{array}$ & $\begin{array}{c}0.064 * * * \\
(0.013)\end{array}$ & $\begin{array}{c}0.061 * * * \\
(0.013)\end{array}$ & $\begin{array}{c}0.064 * * * \\
(0.013)\end{array}$ & $\begin{array}{c}0.060 * * * \\
(0.013)\end{array}$ & $\begin{array}{c}0.058^{* * *} \\
(0.013)\end{array}$ & $\begin{array}{c}0.055^{* * *} \\
(0.013)\end{array}$ & $\begin{array}{c}0.053 * * * \\
(0.013)\end{array}$ & $\begin{array}{c}0.060 * * * \\
(0.013)\end{array}$ \\
\hline Reform & $\begin{array}{l}-0.002 \\
(0.003)\end{array}$ & $\begin{array}{l}-0.005 \\
(0.003)\end{array}$ & $\begin{array}{c}-0.002 * * * \\
(0.001)\end{array}$ & $\begin{array}{c}0.031 * * * \\
(0.007)\end{array}$ & $\begin{array}{c}-0.002 * * \\
(0.001)\end{array}$ & $\begin{array}{c}0.011^{* * *} \\
(0.003)\end{array}$ & $\begin{array}{c}-0.009 * * * \\
(0.003)\end{array}$ & $\begin{array}{c}-0.004^{* * *} \\
(0.001)\end{array}$ & $\begin{array}{c}0.022 * * * \\
(0.005)\end{array}$ & $\begin{array}{c}0.018 * * * \\
(0.004)\end{array}$ \\
\hline Observations & 3,368 & 3,368 & 3,368 & 3,368 & 3,368 & 3,368 & 3,368 & 3,368 & 3,368 & 3,368 \\
\hline \multirow[t]{3}{*}{$\mathrm{R}^{2}$} & 0.687 & 0.687 & 0.688 & 0.688 & 0.688 & 0.688 & 0.688 & 0.692 & 0.690 & 0.688 \\
\hline & $\begin{array}{l}\text { School } \\
\text { evaluation }\end{array}$ & $\begin{array}{l}\text { School } \\
\text { autonomy }\end{array}$ & $\begin{array}{l}\text { Teacher } \\
\text { autonomy }\end{array}$ & $\begin{array}{c}\text { Selectivity } \\
\text { university } \\
\text { access }\end{array}$ & $\begin{array}{c}\text { Expansion } \\
\text { university } \\
\text { access }\end{array}$ & $\begin{array}{l}\text { Increase grant } \\
\text { size }\end{array}$ & $\begin{array}{l}\text { Loan to grant } \\
\text { component }\end{array}$ & Interest rate & $\begin{array}{l}\text { Index of } \\
\text { university } \\
\text { autonomy }\end{array}$ & \\
\hline & (11) & (12) & (13) & (14) & (15) & (16) & (17) & (18) & (19) & \\
\hline Mean years of education & $\begin{array}{c}-0.010 * * * \\
(0.001)\end{array}$ & $\begin{array}{c}-0.010 * * * \\
(0.001)\end{array}$ & $\begin{array}{c}-0.009 * * * \\
(0.001)\end{array}$ & $\begin{array}{c}-0.011^{* * * *} \\
(0.001)\end{array}$ & $\begin{array}{c}-0.009 * * * \\
(0.001)\end{array}$ & $\begin{array}{c}-0.011 * * * \\
(0.001)\end{array}$ & $\begin{array}{c}-0.011 * * * \\
(0.001)\end{array}$ & $\begin{array}{c}-0.011 * * * \\
(0.001)\end{array}$ & $\begin{array}{c}-0.011 * * * \\
(0.001)\end{array}$ & \\
\hline Share of people with graduate parent & $\begin{array}{c}0.062 * * * \\
(0.013)\end{array}$ & $\begin{array}{c}0.061 * * * \\
(0.013)\end{array}$ & $\begin{array}{c}0.058 * * * \\
(0.013)\end{array}$ & $\begin{array}{c}0.081 * * * \\
(0.015)\end{array}$ & $\begin{array}{c}0.061 * * * \\
(0.013)\end{array}$ & $\begin{array}{c}0.079 * * * \\
(0.015)\end{array}$ & $\begin{array}{c}0.089 * * * \\
(0.015)\end{array}$ & $\begin{array}{c}0.085^{* * *} \\
(0.015)\end{array}$ & $\begin{array}{c}0.080 * * * \\
(0.014)\end{array}$ & \\
\hline Reform & $\begin{array}{c}0.012 * * \\
(0.005)\end{array}$ & $\begin{array}{c}0.009 * * \\
(0.004)\end{array}$ & $\begin{array}{c}0.027^{* * * *} \\
(0.003)\end{array}$ & $\begin{array}{c}0.007 * * \\
(0.004)\end{array}$ & $\begin{array}{c}-0.013^{* * *} \\
(0.003)\end{array}$ & $\begin{array}{c}0.012 \\
(0.008)\end{array}$ & $\begin{array}{c}-0.046 * * * \\
(0.013)\end{array}$ & $\begin{array}{c}-0.041 * * * \\
(0.014)\end{array}$ & $\begin{array}{l}0.009 * \\
(0.005)\end{array}$ & \\
\hline Observations & 3,368 & 3,368 & 3,368 & 2,271 & 3,368 & 2,271 & 2,271 & 2,271 & 2,461 & \\
\hline $\mathrm{R}^{2}$ & 0.687 & 0.687 & 0.690 & 0.707 & 0.689 & 0.707 & 0.708 & 0.707 & 0.714 & \\
\hline
\end{tabular}

Notes: robust standard errors in brackets $-* * * p<0.01, * * p<0.05, * p<0.1$; Regressions are weighted by the number of observations used to compute inequality indices in each
country-cohort-survey cell. All regressions include controls for the share of female in each cell and for country, cohort, and survey fixed effects. \#: no reform data for Estonia, Hungary, Latvia, Poland, Slovak Rp., Slovenia and Czech Rp.; \#\# : no reform data for Estonia, Hungary, Latvia, Poland, Slovak Rp. and Slovenia 


\subsection{Robustness checks}

In this section we present several robustness checks for our main results.

First, we perform our baseline estimation of equation (1) by collapsing data by country and year of birth. Also when reducing the sample size and exploiting only the relevant source of variation the estimated effects of reforms on education attainment remain unaffected (not reported).

Second, we perform separate regressions for the four surveys. Since not all countries are covered in the four dataset (see table B1 in the Appendix B), we restrict this analysis only to the subsample of the ten countries included in all the surveys ${ }^{34}$ in order to have a balanced sample in the different regressions. The results are reported in table B3 and shows that the signs of the reforms (when are significant - those not significant are clearly identified by others countries excluded from the analysis) are broadly consistent across datasets. ${ }^{35}$

As a third sensitivity test, in order to check whether the results are driven by the behaviour of a single country, we re-estimate the baseline linear regression excluding from the sample one country at a time, and we found that all our results are still in place and are not driven by the behaviour of a single country (not reported).

Finally, we performed the analysis on the distributional effects of reforms using alternative measures of inequality, namely the Gini index and Atkinson 0.5. Although different indices are more sensitive to different parts of the distribution, no significant differences appear in the estimated coefficient when alterative measures are used. Overall, we can conclude that all results of our previous section are robust to alternative specifications.

\subsection{First summing up}

We now summarise our findings on the impact of each specific reform on the distribution of educational attainments in the population. Our main claim is that reforming educational institutions has a causal impact on individual choices. Several arguments support this claim. First of all, reforms are exogenous to individual choice. Not only reform variables are matched to people at the beginning of their educational career, but they are also not affected by past educational choices. Second, the impact of each reform is identified by means of a diff-in-diff strategy. Third, confounding factors are adequately controlled for by country, birth year and survey fixed effect; in addition a country specific time trend takes care of different stages of mass schooling occurred in different countries over different periods of last century. Fourth, when a falsification test is performed through a random match of institutional features to individuals, the results discussed in the previous section do not hold any more. Table B4 and B5 in Appendix B report the results of the estimated coefficient of equation (1) when the merging rule is performed according to a randomly generated series of years of birth, in the first case, and a randomly generated series of country of birth in the second case. In both cases, in contrast to the estimated coefficients in our original regressions, the coefficients of the Reform variables in the falsification regressions are almost always statistically insignificant and when statistically different from zero

\footnotetext{
${ }^{34}$ These countries are Czech Republic, Germany, Hungary, Ireland, Italy, Netherlands, Poland, Slovenia, Sweden, Great Britain.

${ }^{35}$ Empty cells are due to the different survey periods, which does not allow for a sufficient number of observations identifying the impact of a specific reform.
} 
the sign in not the one expected according to the underlying theory. These findings suggest that our original regressions actually capture the true effect of changes in the educational setting and are therefore consistent with the causal interpretation of the results.

A second claim is that educational reforms exhibit heterogeneous effects over the population, and this allows us to identify which portion of the distribution is mostly affected. Our estimates allow for investigating the content of each reform measure in terms of mean and dispersion of individual educational attainment. Unfortunately, except few cases where the reform are measured in terms of years, we do not have level measure of the reform and therefore we cannot provide a reliable estimate of the magnitude of the impact, which would allow cost-benefit analysis.

The results of the estimates reported in tables 6 and 10 and depicted in figure 3 are recapped in table 11. By looking at the impacts on mean and dispersion, we identify three types of reforms:

a) reforms that raise the mean educational attainment in the population while reducing its dispersion; given an implicit limit to the amount of schooling achievable, these reforms are effective by raising the attainment of the bottom tail. We call them inclusive.

b) reforms that raise the mean educational attainment while increasing its variation within the population. While the distribution of years of education is shifted to the right, at least one of the two tails has to become more elongated: either low achievers are not affected by the reform (and therefore loose terrain with respect to the mean) or high achievers are stimulated by it (and therefore grow beyond the mean). We call these reforms selective.

c) a third group of reforms obtain a reduction in the mean accompanied by an increase in dispersion. This may occur either because they were purposely intended to limit the expansionary trend in education, or because they revealed a failure ex-post. We call these reforms as restrictive.

According to these criteria we are able to classify all reforms but two, because the estimated coefficients do not go in accordance with either the classification scheme (pre-primary school teacher qualification) or with theoretical expectation (school autonomy). They are indicated by a question mark. In the first case, we do not want to create a fourth category (lower mean and dispersion) and we arbitrarily attribute it to the restrictive policies, giving more weight to the mean reducing impact. In the second case mean effects are statistically insignificant, while decile and inequality index results are contradictory between them; we have classified it in accordance with teacher autonomy. ${ }^{36}$

\footnotetext{
36 Notice that we have classified loan to grant components and interest rate on student loan as inclusive by interpreting them in a reverse way, like beginning age of compulsory education: lowering the cost oaf accessing universities (either through increase in the grant component or by means of interest rate reduction) has a positive impact on both mean and equality in years of education.
} 
Table 11: Impact of the reform on the distribution of years of schooling in the population 24 European countries - 1929-2000

\begin{tabular}{|c|c|c|c|c|}
\hline REFORM & $\begin{array}{l}\text { impact on } \\
\text { the mean }\end{array}$ & $\begin{array}{c}\text { impact on } \\
\text { equality } \\
\text { (deciles) }\end{array}$ & $\begin{array}{c}\text { impact on } \\
\text { equality } \\
\text { (Atkinson) }\end{array}$ & nature of the reform \\
\hline Pre-primary expansion & + & \pm & \pm & inclusive ( $\uparrow$ mean $\approx$ dispersion) \\
\hline Pre-primary school teacher qualification & - & + & \pm & restrictive ? ( $\downarrow$ mean $\uparrow$ dispersion) \\
\hline Duration compulsory education & + & + & + & inclusive ( $\uparrow$ mean $\downarrow$ dispersion) \\
\hline Beginning age of compulsory education & - & - & - & inclusive ( $\uparrow$ mean $\downarrow$ dispersion) \\
\hline Leaving age of compulsory education & + & + & + & inclusive ( $\uparrow$ mean $\downarrow$ dispersion) \\
\hline Primary school teacher qualification & \pm & \pm & - & selective ( $\approx$ mean $\uparrow$ dispersion) \\
\hline Secondary school teacher qualification & + & - & + & inclusive ( $\uparrow$ mean $\approx$ dispersion) \\
\hline Tracking age & \pm & \pm & + & inclusive ( $\approx$ mean $\downarrow$ dispersion) \\
\hline Standardised test (for career advancement) & - & + & - & restrictive ( $\downarrow$ mean $\approx$ dispersion) \\
\hline Standardised test (for other purposes) & + & - & - & selective ( $\uparrow$ mean $\uparrow$ dispersion) \\
\hline School evaluation & \pm & \pm & - & selective ( $\approx$ mean $\uparrow$ dispersion) \\
\hline School autonomy & \pm & + & - & selective ? ( $\approx$ mean $\approx$ dispersion) \\
\hline Teacher autonomy & \pm & - & - & selective ( $\approx$ mean $\uparrow$ dispersion) \\
\hline Selectivity in university access & - & - & - & restrictive ( $\downarrow$ mean $\uparrow$ dispersion) \\
\hline Expansion of university access & + & \pm & + & inclusive ( $\uparrow$ mean $\downarrow$ dispersion) \\
\hline Increase grant size & \pm & - & \pm & selective ( $\approx$ mean $\uparrow$ dispersion) \\
\hline Loan component to grant component & - & + & + & inclusive ( $\uparrow$ mean $\downarrow$ dispersion) \\
\hline Interest rate & - & + & + & inclusive ( $\uparrow$ mean $\downarrow$ dispersion) \\
\hline Index of university autonomy & - & - & - & restrictive ( $\downarrow$ mean $\uparrow$ dispersion) \\
\hline
\end{tabular}

\subsection{Factor Analysis}

If we have been able to convince the reader that our measures of educational reforms identify causal impacts on educational attainment in the European population over the last century, we can now move to discuss a separate problem, which is the fact that the reforming activity of governments may involve more than one dimension at a time. It is also likely that government with different political orientation choose policies which are consistent among them in terms of orientation (see paragraph 5.6). We have experimented with the inclusion of more than one reform variable in the regressions, but the number of potential combinations is almost infinite and the multicollinearity impedes identifying statistically significant effects. ${ }^{37}$

One possible solution is to reduce the dimensionality of the problem, via the identification of latent variables underlying our measures of reform activity of governments. To this goal, we apply factors analysis to original reform measures extracting factors that we consider as better accounting of institutional reforming activities prevailing in European countries over the last century. We will show that these latent variables (which are nothing more than linear combinations of original ones) have consistent impacts on educational attainment and inequality.

${ }^{37}$ Given 20 potential regressors, the number of all possible groups of regressors of variable size is given by the following formula $N=\sum_{i=1}^{20}\left(\begin{array}{l}20 \\ i\end{array}\right)=\sum_{i=1}^{20}\left(\frac{20 !}{(20-i) ! i !}\right)=1048574$. However, if we include all the 19 reform variables together in estimating equation (1), we find positive (and statistically significant) effects of pre-primary teacher qualification, leaving age compulsory (while beginning is negative and duration is excluded for full collinearity reason), standardised test for evaluation, increased grant size; negative and significant effects are instead found for primary teacher qualification, tracking age, standardised test for career, school evaluation, selectivity in university access, loan to grant component, interest rates and university autonomy. All signs are consistent with what have reported in table 6 (but in the case of pre-primary teacher qualification), but obviously statistical significance does not coincide. 
The mere application of this statistical technique to the whole group of reform variables retains seven factors, which are then difficult to interpret (even after rotation). For this reason we have preferred to partition the entire list into subgroups, which in our opinion are sufficiently homogenous, then retaining the first factor only. ${ }^{38}$ The subgroup are formed according to the area of policy intervention and the orientation of the policy, as emerged from previous analysis summarised in table 11, with few exceptions. ${ }^{39}$ Table 12 provides information on the extraction of the first principal components. The second, third, and fourth columns indicate the factor order, the associated eigenvalue and the cumulative proportion of the overall variance explained by each factor. Columns 5 and 6 specify the correlation between each original variable and the first factor extracted (the factor loading), as an indication of the contribution of variable to the constructed index.

We have named each extracted factor according to the nature of the reforms involved. The first one (named compulsory) gathers all reforms associated to the introduction/modification of obligations to attend specific stage of schooling; the first factor accounts for $68 \%$ of the overall variance of the original four variables. Notice that the original variables are right-sign correlated with the factor, because a decrease in starting age increases the compulsoriness of a schooling system. The second factor (named comprehensive) summarises the contribution of policies intended to retain students within the schools; it accounts for $59 \%$ of the overall variance. The third and fourth factors (named university support 1 and university support 1) collect all information available about university admission policies and student financial support. The first component extracted captures only a limited fraction of total variance (42\%), mostly due to its weak association of the reforms on grant allowances; therefore, we retained a second factor that explains an additional $28 \%$ of the overall variance. . We claim these four factors correspond to the notion of inclusive reforms, because they mostly succeed through raising the educational attainment of low achievers.

The fourth group (indicated as accountability) consists of reforms associated to measuring student/school performances in order to provide more teacher/school autonomy; the extracted factor accounts for half of the original variance. The fifth group (named teacher qualification) includes all reforms associated to rises in required qualification for teachers, at different educational level; it corresponds to $70 \%$ of the underlying variance. Finally, the sixth group (named university autonomy) collects the original indicators of university autonomies (budget, recruitment, organization, logistic, courses organization, self-evaluation and development plans), and accounts for the largest share of the original variance (78\%). ${ }^{40}$ This second group of factors corresponds to the notion of selective/restrictive reforms, which in general are more effective for high achievers and may contribute to increasing educational inequality.

\footnotetext{
${ }^{38}$ Only in the third groups of table 12 there is evidence of a second factor available (i.e. the associated eigenvalues exceeds unity), which has pushed us to retain two orthogonal factors in this case.

39 The exceptions are the following: "increase grant size" was grouped together with other measures supporting student access to tertiary education (despite emerging as selective in previous analysis - see also the specific discussion about this variable); "secondary school teacher qualification" has been grouped together with other variables concerned with teacher qualifications at other stages of education (despite appearing as inclusive in our analysis). Finally, "selectivity in university access" is clearly a selective policy, but has been left with the group of variables related to university access because all variables in the group are available for a reduced number of countries.

${ }^{40}$ While the variable used in previous paragraphs (index of university autonomy) was simply a normalised sum of the constituent variables, in the present case the weights are given by factor loadings; nevertheless their correlation between the two measures is 0.99 .
} 
We now make use of these factors as representative of the educational policies followed by different governments across years, also providing a rough description of country policy stances. Then, we replicate previous models and estimate their impact onto educational attainment and inequality.

Table 12: Factor analysis - principle component method

\begin{tabular}{|c|c|c|c|c|c|c|c|c|}
\hline & & Factors & Eigenvalue & $\begin{array}{c}\text { Cumulative } \\
\text { variance } \\
\text { explained } \\
\end{array}$ & Name of original variable & \multicolumn{2}{|c|}{ Factor loading } & countries available \\
\hline \multirow{10}{*}{ 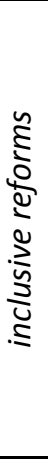 } & \multirow[t]{3}{*}{ Compulsory } & 1 & 2.056 & 0.685 & Duration compulsory school & \multicolumn{2}{|c|}{0.999} & \multirow{3}{*}{24} \\
\hline & & 2 & 0.944 & 1 & Beginning age of comp. education & & & \\
\hline & & 3 & 0 & 1 & Leaving age of comp. education & & & \\
\hline & \multirow[t]{3}{*}{ Comprehensive } & 1 & 1.761 & 0.587 & Pre-primary expansion & & & \multirow{3}{*}{24} \\
\hline & & 2 & 0.707 & 0.823 & Tracking age & & & \\
\hline & & 3 & 0.532 & 1 & Expansion of university access & \multicolumn{2}{|c|}{0.785} & \\
\hline & University support 1 & 1 & 1705 & 0.426 & Selectivity university access & 0.49 & 0.70 & \multirow{4}{*}{$\begin{array}{c}17 \text { (no Estonia, } \\
\text { Hungary, Latvia, } \\
\text { Poland, Slovak Rp., } \\
\text { Slovenia and Czech } \\
\text { Rp.) }\end{array}$} \\
\hline & \multirow[t]{3}{*}{ University support 2} & 2 & 1.128 & 0.708 & Increase grant size & 0.31 & 0.56 & \\
\hline & & 3 & 0.899 & 0.933 & Loan to grant component & 0.91 & -0.13 & \\
\hline & & 4 & 0.268 & 1 & Interest rate & 0.74 & -0.55 & \\
\hline \multirow{15}{*}{ 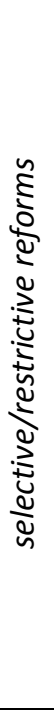 } & \multirow[t]{5}{*}{ Accountability } & 1 & 2.445 & 0.489 & Standardised tests (for career adv) & & & \multirow{5}{*}{24} \\
\hline & & 2 & 0.941 & 0.677 & Standardised tests (for other purp) & & & \\
\hline & & 3 & 0.734 & 0.824 & School evaluation & & & \\
\hline & & 4 & 0.561 & 0.936 & School autonomy & & & \\
\hline & & 5 & 0.319 & 1 & Teacher autonomy & & & \\
\hline & \multirow[t]{3}{*}{ Teacher qualification } & 1 & 2.126 & 0.709 & Pre-primary teacher qualification & & & \multirow{3}{*}{24} \\
\hline & & 2 & 0.622 & 0.916 & Primary teacher qualification & & & \\
\hline & & 3 & 0.252 & 1 & Secondary teacher qualification & & & \\
\hline & \multirow[t]{7}{*}{ University autonomy } & 1 & 5.448 & 0.778 & Budget autonomy & & & \multirow{7}{*}{$\begin{array}{l}18 \text { (no Estonia, } \\
\text { Hungary, Latvia, } \\
\text { Poland, Slovak Rp. } \\
\text { and Slovenia) }\end{array}$} \\
\hline & & 2 & 0.459 & 0.844 & Recruitment autonomy & & & \\
\hline & & 3 & 0.325 & 0.89 & Organization autonomy & & & \\
\hline & & 4 & 0.282 & 0.931 & Logistic autonomy & & & \\
\hline & & 5 & 0.238 & 0.965 & Course autonomy & & & \\
\hline & & 6 & 0.152 & 0.987 & Self-evaluation & & & \\
\hline & & 7 & 0.095 & 1 & Development plan autonomy & & & \\
\hline
\end{tabular}

Let us also remind that by construction each factor has zero mean and unitary standard deviation, and therefore it may be used to rank countries and/or to study temporal evolution, but it is scalefree. In figure 4 we plot the dynamics of each reform factor for the average of the countries. It comes with no surprise that all measures are upward trended, since by construction each reform is summed (subtracted) to another if it has the same (opposite) orientation. The general message of the graph is that European educational systems underwent significant reforms during last century, and nevertheless they followed different orientations. If we take the zero value as a reference point, we observe that at the European level the first wave of reforms in the 60's involved the expansion of compulsory education, followed by a second wave of expansion of comprehensive schools at the beginning of the 70's. Widening school access required recruiting more teachers, which led to reforms raising the qualification requirements to enter the profession during the 70's. At the beginning of the 80's the pressure for increasing the access to universities led many countries to widen admission rules and/or to introduce grant policies for financially constrained students. Another common trend experienced by European countries is towards 
increased autonomy for universities, which took off at the end of the 70's and continued during the 80 's and 90 "s. Eventually, by the end of the 90's we also witness greater emphasis towards the accountability of the educational systems, which pushed many countries to establishing national assessment agencies.

Figure 4: Temporal evolution of reform factors
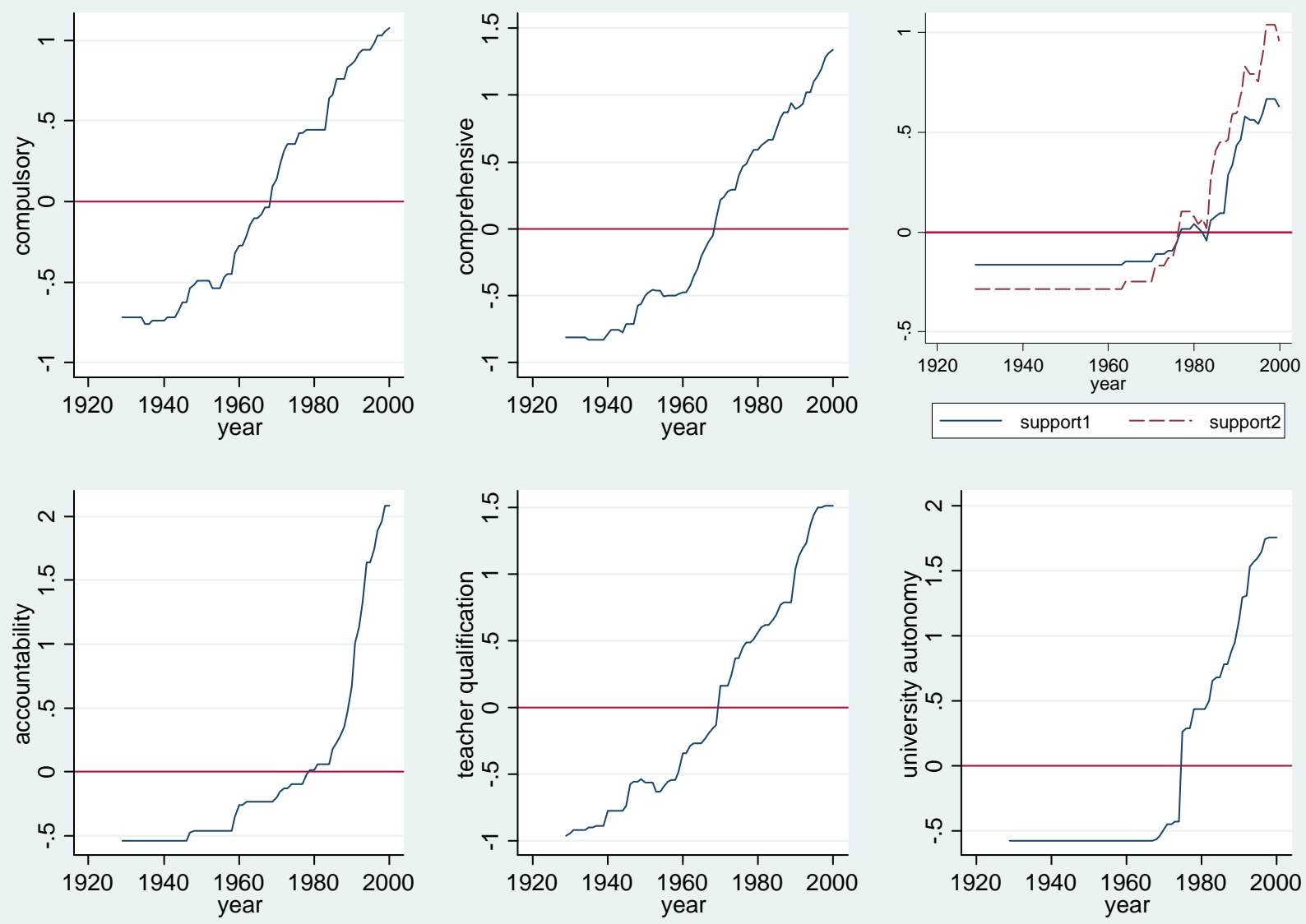

Not all countries were alike in reforming their educational system. We know from the literature that the Nordic countries were first in revising their secondary school systems in a comprehensive direction (Leschinsky and Mayer 1990). Can we use our data to characterise different national experiences? The answer is positive. For ease of readability we have replicated the factor analysis over the two groups of variables, classified in table 12 as belonging to either the set of inclusive or selective/restrictive policies. By so doing we identify a unique inclusive policies factor and a unique selective/restrictive policies factor (see table B6 in Appendix B). By construction, the original variables exhibit stronger correlations to the summary measure of the group they belong to. Therefore, we can study which is the general orientation in educational policy of each country, according to our proposed classification. Country means for both factors are plotted in figure $5 .{ }^{41}$

By looking at figure 5 we notice that Anglo-Saxon countries (Britain and Northern Ireland, but also Sweden) were the countries which score highest along the selective/restrictive policies dimension, while Nordic countries (notably Norway and Finland, in company of French Belgium) exhibit higher scores along the inclusive policies axis. The Mediterranean countries (Greece, Italy, Portugal and

${ }^{41}$ Country averages for specific factors extracted in table 12 are reported in table B7 in Appendix B. 
Spain), together with Austria and Flemish Belgium, are all gathered in a low reforming area in the south-west quadrant. More specifically, Portugal and Spain are associated with negative scores along the inclusive axis, while Italy, and at a lesser extent France and Greece, attain negative scores along the selective/restrictive axis. The same kind of country partition tends to occur again whenever we match the original six extracted factors. ${ }^{42}$

Figure 5: Country average location with respect to policy stances

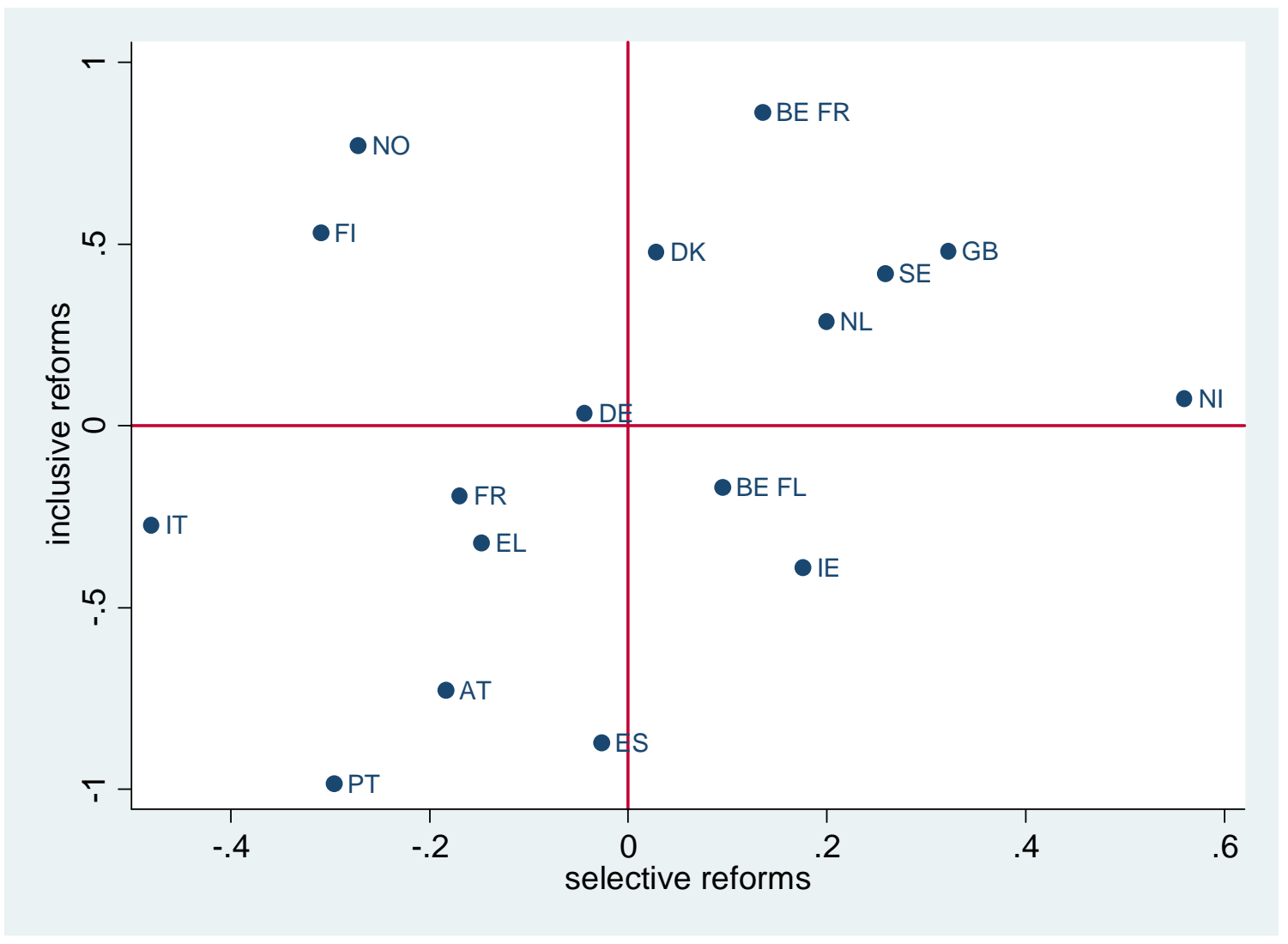

In order to remain convinced that these factors share the predictive capability of original reform variables, we have also re-estimated equations (1)-(3)-(4) replacing single reforms with the newly extracted seven factors. In table 13 we report the relevant coefficients for equation (1), while table 14 shows the relevant coefficients corresponding to equation (4). We observe that inclusive reforms (compulsory and comprehensive factors) raise the average educational attainment, while the facto university support, computed on a subset of countries, tend to reduce educational attainment. ${ }^{43}$ When we consider selective/restrictive reforms, two factors are positively correlated with educational attainment (accountability and teacher qualification), while university autonomy exhibit no statistically significant correlation.

These conclusions are partially supported by regressions on different deciles of the distribution (shown in figure 6). For inclusive policies the typical profile is an inverted U-shaped trajectories, implying that low to middle achievers are the main target of the policies, since they exhibit stronger impact than people from better backgrounds. On the contrary for selective policies we observe diversified patterns, depending on the variable considered: teacher qualification and accountability exhibit a declining trend, thus negatively affecting the educational attainment of

\footnotetext{
${ }^{42}$ Available from the authors.

${ }^{43}$ Notice that the second factor is mostly driven by "Selectivity in university access", though mitigated by "grant size".
} 
intermediate and high achievers, university autonomy has an inequality enhancing effect, by reducing educational attainment at the bottom of the distribution and raising it at its top.

Table 13: Reforms (factors) and educational attainment

\begin{tabular}{|c|c|c|c|c|c|c|c|}
\hline & \multicolumn{4}{|c|}{ inclusive reforms } & \multicolumn{3}{|c|}{ selective reforms } \\
\hline & compulsory & comprehensive & $\begin{array}{l}\text { university } \\
\text { support } 1 \\
\end{array}$ & $\begin{array}{l}\text { university } \\
\text { support } 2 \\
\end{array}$ & accountability & $\begin{array}{c}\text { teacher } \\
\text { qualification }\end{array}$ & $\begin{array}{l}\text { university } \\
\text { autonomy }\end{array}$ \\
\hline \multirow{3}{*}{ Graduate parent } & (1) & (2) & (3) & (4) & (5) & (6) & $(7)$ \\
\hline & 3.260 *** & $3.094^{\star * *}$ & $3.232^{\star \star \star}$ & $3.012^{\star \star *}$ & $2.916^{\star \star \star}$ & $3.138^{* * *}$ & $3.172^{\star \star \star}$ \\
\hline & {$[0.042]$} & {$[0.042]$} & {$[0.050]$} & {$[0.055]$} & {$[0.039]$} & {$[0.043]$} & [0.051] \\
\hline \multirow[t]{2}{*}{ Reform (factor) } & $0.210 * \star *$ & $0.086 * \star *$ & 0.036 & $-0.243^{\star \star *}$ & $0.185^{\star \star \star}$ & $0.095^{\star \star *}$ & 0.027 \\
\hline & {$[0.027]$} & {$[0.025]$} & {$[0.071]$} & {$[0.050]$} & {$[0.038]$} & {$[0.025]$} & {$[0.027]$} \\
\hline Observations & 329,102 & 329,102 & 224,969 & 224,969 & 329,102 & 329,102 & 240,482 \\
\hline $\mathrm{R}^{2}$ & 0.260 & 0.259 & 0.290 & 0.288 & 0.259 & 0.259 & 0.284 \\
\hline Countries & 24 & 24 & 17 & 17 & 24 & 24 & 18 \\
\hline
\end{tabular}

Note: standard errors clustered by country $\times$ age cohorts in brackets - *** $p<0.01, * * p<0.05, * p<0.1-$

Constant, gender, birth year, country and survey controls, country specific time trend included

We finally move to the direct estimation of equation (4) using again the Atkinson index $(\varepsilon=2)$ as our inequality indicator, to be considered as dependent variable. From previous discussion, we would expect a negative correlation between inclusive reforms (factor) and educational inequality, while correlation can be either sign for selective/restrictive policies. In table 14 we observe that as the population becomes on average more educated, inequality tends to decrease (due to the years of education being a top-censored variable). We also note that environmental factors (as proxied by the share of individuals with college educated parents) are associated with higher inequality, while the share of females in each cell is associated with lower inequality (not shown in the table). The same table 14 shows that inclusive reforms are positively associated with inequality reduction for compulsory and comprehensive factors, while again university support2 factor behaves consistently as a factor belonging to the group of selective reforms. The selective/restrictive reforms (accountability in particular) have an inequality enhancing contribution, while teacher qualification behaves as a reform with an inclusive nature (because it raises the mean and lowers the dispersion).

Table 14: Dependent variable: Atkinson index $(\varepsilon=2)$

\begin{tabular}{|c|c|c|c|c|c|c|c|}
\hline & \multirow[b]{2}{*}{ Compulsory } & \multicolumn{3}{|c|}{ Inclusive reforms } & \multicolumn{3}{|c|}{ Selective reforms } \\
\hline & & $\begin{array}{l}\text { comprehens } \\
\text { ive }\end{array}$ & $\begin{array}{l}\text { university } \\
\text { support } 1\end{array}$ & $\begin{array}{l}\text { university } \\
\text { support } 2\end{array}$ & $\begin{array}{c}\text { Accountabilit } \\
y\end{array}$ & $\begin{array}{c}\text { teacher } \\
\text { qualification }\end{array}$ & $\begin{array}{l}\text { university } \\
\text { autonomy }\end{array}$ \\
\hline Mean years of education & $\begin{array}{c}-0.009 * \star \star \\
(0.001)\end{array}$ & $\begin{array}{c}-0.009 * * * \\
(0.001)\end{array}$ & $\begin{array}{c}-0.011^{\star * *} \\
(0.001)\end{array}$ & $\begin{array}{c}-0.011^{\star \star \star} \\
(0.001)\end{array}$ & $\begin{array}{c}-0.010^{\star \star \star} \\
(0.001)\end{array}$ & $\begin{array}{c}-0.010^{\star \star *} \\
(0.001)\end{array}$ & $\begin{array}{c}-0.011^{\star \star \star} \\
(0.001)\end{array}$ \\
\hline Share of people wth graduate parent & $\begin{array}{c}0.064^{\star \star *} \\
(0.013)\end{array}$ & $\begin{array}{c}0.057^{\star \star \star} \\
(0.013)\end{array}$ & $\begin{array}{c}0.082^{\star \star *} \\
(0.015)\end{array}$ & $\begin{array}{c}0.083^{\star \star \star} \\
(0.014)\end{array}$ & $\begin{array}{c}0.059 * * * \\
(0.013)\end{array}$ & $\begin{array}{c}0.061^{* * *} \\
(0.013)\end{array}$ & $\begin{array}{c}0.081^{\star * *} \\
(0.014)\end{array}$ \\
\hline Reform (factor) & $\begin{array}{c}-0.004^{\star \star \star} \\
(0.001)\end{array}$ & $\begin{array}{c}-0.009 * * \star \\
(0.001)\end{array}$ & $\begin{array}{l}-0.005 \\
(0.004)\end{array}$ & $\begin{array}{c}0.006^{\star \star \star} \\
(0.002)\end{array}$ & $\begin{array}{c}0.012^{\star \star \star} \\
(0.002)\end{array}$ & $\begin{array}{c}-0.005^{\star \star \star} \\
(0.002)\end{array}$ & $\begin{array}{c}0.002 \\
(0.001)\end{array}$ \\
\hline Observations & 3,368 & 3,368 & 2,271 & 2,271 & 3,368 & 3,368 & 2,461 \\
\hline $\mathrm{R}^{2}$ & 0.688 & 0.692 & 0.706 & 0.708 & 0.691 & 0.688 & 0.714 \\
\hline
\end{tabular}

Notes: robust standard errors in brackets - *** $\mathrm{p}<0.01,{ }^{* *} \mathrm{p}<0.05, * \mathrm{p}<0.1$; Regressions are weighted by the number of observations used to compute inequality indices in each country-cohort-survey cell. All regressions include controls for country, cohort, and survey fixed effects 
Figure 6: impact of reforms (factors) on different deciles of educational attainment - estimated coefficients (and $90 \%$ confidence intervals)

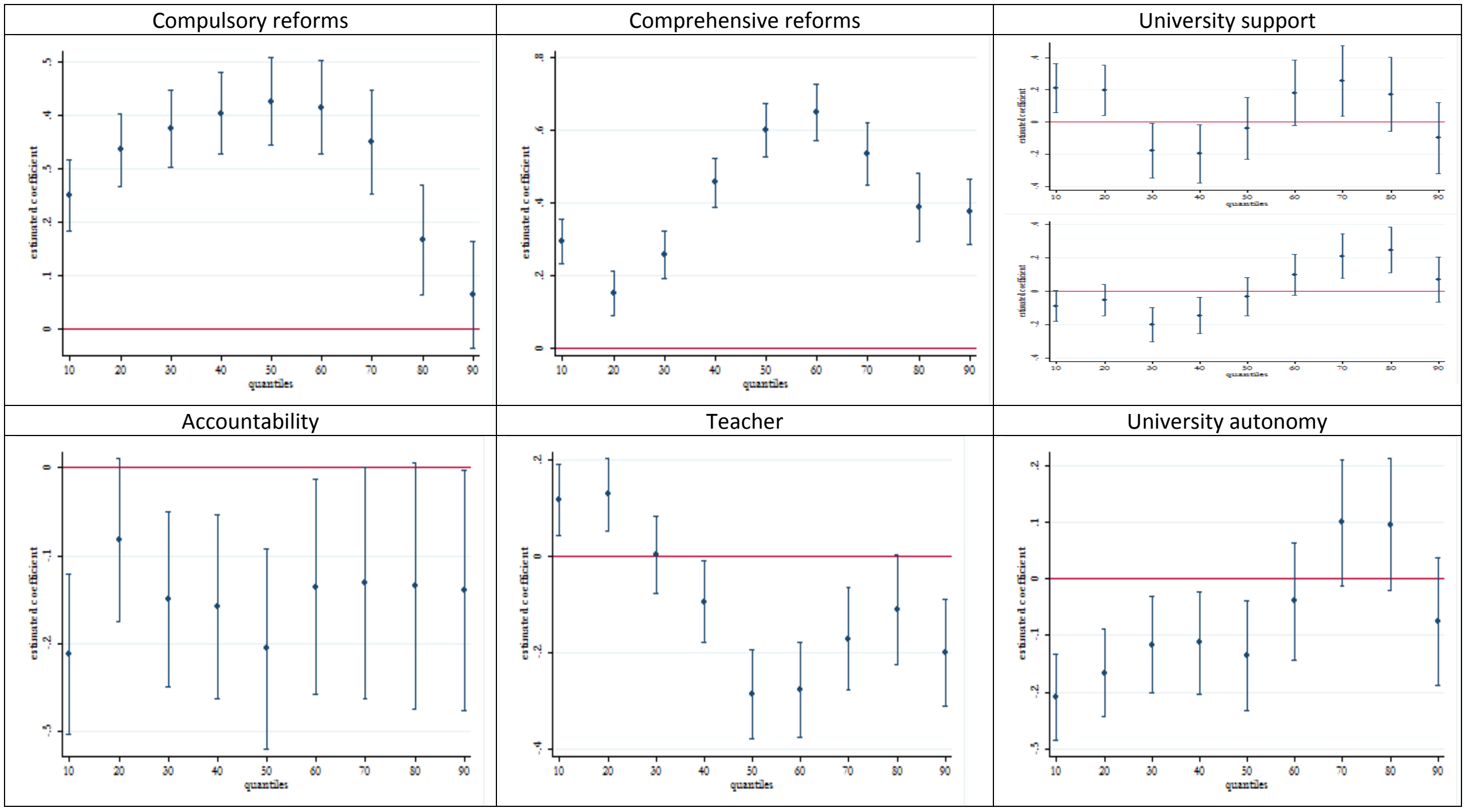




\subsection{Educational reforms and political orientation}

In the previous section we have proposed a possible grouping of the variables describing the reforming activities of governments. We have also shown that seven (or even two) groups can adequately characterise the areas of intervention, while retaining their correlation with educational attainment in the population. In this final section we ask ourselves what drives the reforming activities of governments in the area of education.

Educational reforms can be considered as structural reforms, which require a sufficiently long period to yield some result. For this reason, they cannot be undertaken frequently and, in general, they require a wide support, both in the parliament and in the public opinion. However, political parties have different opinions with respect to what is the appropriate skill composition in the domestic labour force, as well as about the desirable degree of social differentiation. Both variables crucially depend on the distribution of educational attainment in the population, which can be modified by policy interventions (as we have shown in previous sections).

We deem plausible to assume that parties with a left-wing orientation are strongly supportive inclusive policies, because they benefit the lower tail of the educational attainment distribution, where their supporters are largely over-represented. In addition, they may expect a more intense political participation of low class people, which should translate in stronger electoral support. ${ }^{44}$ Moreover, leftist parties may support generalised expansion of schooling as a poverty alleviation measure (Brady 2003) and/or as a mean of increasing public expenditure (Hicks and Swank 1992, Moller et al. 2003).

Conversely, conservative parties tend to oppose any generalised expansion of schooling, for at least two reasons: on one side educational activities are highly labour-intensive, and therefore they induce expansion in public expenditure; on the other side, they raise people expectations in terms of future life-time income, which may translate in higher wage pressure and rigidities. In both cases, policies are undertaken under varying external circumstances, concerning growth and availability of public resources. Parties' differences may have been attenuated in recent years due to reduced ability to financing public expenditure (Korpi and Palme 2003), but given our long run perspective, this concern may be less pertinent.

Following this line of argument, we have then analysed the correlation between our measures of reforms and political orientation of (democratically elected) governments in the countries we have considered so far. Data on policy orientation of political parties elected in parliament and selected cabinets are taken from ParlGov database (Döring and Manow 2010). A less detailed source of data is from Woldendorp, Keman and Budge (2000). External circumstances are controlled for using data from Penn World Tables v.7.0. Descriptive statistics are reported in table 15.

\footnotetext{
${ }^{44}$ Gradstein and Justman 1999 considers a model where expansion of education expand the franchise, thus moving the median voter towards the bottom and raising the electoral support for more egalitarian taxation, which in turn translates into more resources invested in education.
} 
Table 15: Political variables - descriptive statistics

\begin{tabular}{|c|c|c|c|c|c|c|c|c|}
\hline & Mean & $\begin{array}{c}\text { Std. } \\
\text { Dev. } \\
\text { (overall) }\end{array}$ & $\begin{array}{c}\text { Std. } \\
\text { Dev. } \\
\text { (betwee } \\
\text { n) }\end{array}$ & $\begin{array}{c}\text { Std. } \\
\text { Dev. } \\
\text { (within) }\end{array}$ & Min & $\operatorname{Max}$ & Obs. & $\begin{array}{c}N . \text { of } \\
\text { countrie } \\
\mathrm{S}\end{array}$ \\
\hline $\begin{array}{l}\text { right-wing orientation of the government (Döring and Manow } \\
\text { 2010) }\end{array}$ & 5.119 & 1.506 & 0.775 & 1.308 & 0 & 8.154 & 928 & 24 \\
\hline right-wing orientation of the parliament (Döring and Manow 2010) & 5.095 & 0.756 & 0.648 & 0.558 & 0 & 7.194 & 928 & 24 \\
\hline cabinet support in the parliament (Döring and Manow 2010) & 0.562 & 0.124 & 0.07 & 0.097 & 0.123 & 1 & 928 & 24 \\
\hline $\begin{array}{l}\text { political complexion of parliament and government (Woldendorp, } \\
\text { Keman and Budge } 2000 \text { - rank-reversed for comparability) }\end{array}$ & 5.8 & 1.895 & 1.069 & 1.666 & 2 & 10 & 940 & 24 \\
\hline $\begin{array}{l}\text { Log of PPP Converted GDP Per Capita at } 2005 \text { constant prices } \\
\text { (Penn World Tables v.7.00) }\end{array}$ & 9.604 & 0.5 & 0.33 & 0.411 & 7.869 & 10.71 & 963 & 24 \\
\hline $\begin{array}{l}\text { Government Consumption Share of PPP Converted GDP Per } \\
\text { Capita at } 2005 \text { constant prices (Penn World Tables v. } 7.00 \text { ) }\end{array}$ & 0.103 & 0.028 & 0.028 & 0.011 & 0.027 & 0.21 & 963 & 24 \\
\hline
\end{tabular}

There are some delicate measurement issues when trying to define the political orientation of policy makers. Döring and Manow (2010) have coded each party elected in Parliament on a 0-10 scale, ranging from 0-most left oriented to 10-most right wing oriented. By taking seat-weighted average of parties elected in a legislature or supporting a cabinet, we obtain a measure of the political orientation of policy makers. Given data availability, we also control for strength of cabinets in parliament by taking the share of seats taken by parties supporting a cabinet over the total number of seats available. An alternative measure of the ideological complexion of government and parliament is proposed by Woldendorp, Keman and Budge (2000, which classifies government on a 1 (left wing dominance) to 5 (right wing dominance). ${ }^{45}$ The two sources of data provide information which is consistent among them, as can be seen from the correlation matrix reported in table 16 and from figure 6.

Notice that the ideological orientation of governments is more volatile than the corresponding measure for parliaments, since changing coalitions in order to form cabinets induce noise in this measure. The same graph highlights one additional problem that we face once we take these data to statistical analysis. A group of countries does not have information on the political orientation of democratically elected parties because either there were no free elections (this is the case of dictatorships: Spain, Portugal and Greece) or these entities did not exist as independent states (this is the case of formerly planned economies: Czech and Slovak republics, Estonia, Hungary, Latvia, Poland and Slovenia). This produces an unbalanced panel when studying the correlation between educational policies and ideological stance of governments. ${ }^{46}$

\footnotetext{
${ }^{45}$ The original coding is reversed and halved, but we have converted it for ease of comparability with the variable from Parlgov. Thus 2 is associated to "left-wing dominance (share of seats in Government and supporting parties in parliament larger than 66.6 per cent", 4 is associated to left-centre complexion (share of seats of Left and Centre parties in Government and supporting parties between 33.3 and 66.6 per cent each)", 6 is associated to "balanced situation (share of Centre larger than 50 per cent in Government and in Parliament; or if Left and Right form a government together not dominated by one side or the other" and so on for right-wing dominance.

${ }^{46}$ A further point worth remarking is that in previous sections we have considered two regions of Belgium (Flemish speaking and francophone) as well as Northern Ireland and Britain as separate entities, but they are ruled by a unique identical government. In order to retain the maximum variability across countries/regions, we have retained these regions as separate, since they are characterised by potentially different educational policies.
} 
Table 16: Political variables - correlations

\begin{tabular}{|c|c|c|c|c|c|c|}
\hline - & $\begin{array}{l}\text { right-wing } \\
\text { government }\end{array}$ & $\begin{array}{l}\text { right-wing } \\
\text { parliament }\end{array}$ & $\begin{array}{l}\text { cabinet } \\
\text { support }\end{array}$ & $\begin{array}{c}\text { political } \\
\text { complexion }\end{array}$ & $\begin{array}{l}\text { log gdp per } \\
\text { capita }\end{array}$ & $\begin{array}{l}\text { government } \\
\text { share }\end{array}$ \\
\hline right-wing orientation of the government & 1 & & & & & \\
\hline right-wing orientation of the parliament & $0.6440^{*}$ & 1 & & & & \\
\hline cabinet support in the parliament & -0.0322 & $-0.0755^{*}$ & 1 & & & \\
\hline political complexion of parliament and government & $0.7255^{\star}$ & $0.3973^{\star}$ & $-0.1316^{*}$ & 1 & & \\
\hline log gdp per capita & -0.0225 & $0.1669^{*}$ & $-0.1020^{*}$ & $-0.1587^{*}$ & 1 & \\
\hline government share & $0.0845^{\star}$ & -0.0275 & $0.2454^{*}$ & 0.0627 & $0.2346^{*}$ & 1 \\
\hline
\end{tabular}

Note: * indicates statistically significant at $5 \%$

Figure 7: Ideological orientation of governments

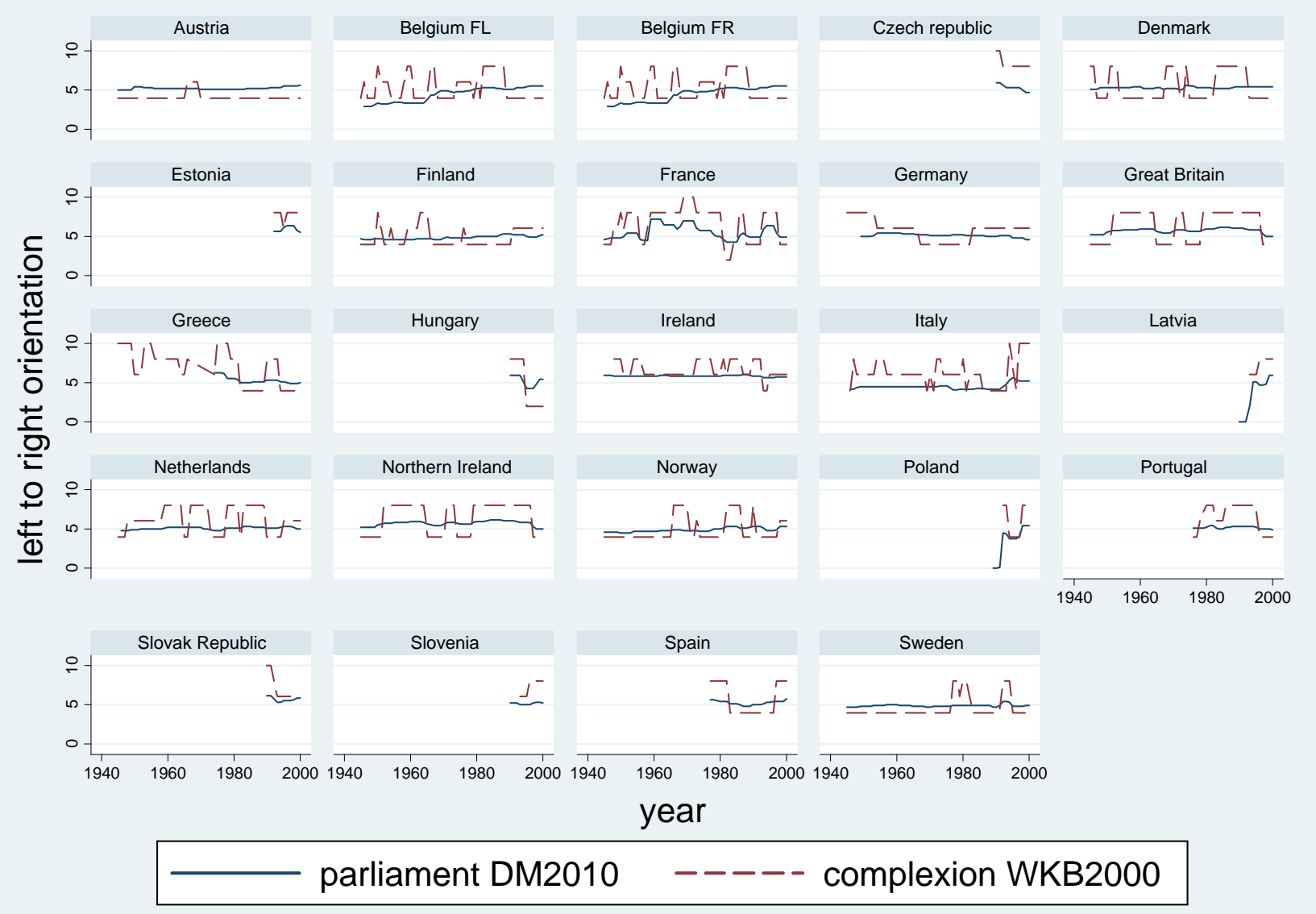

Our dependent variables are the factors extracted from single reform variables in the previous section. By construction, these variables have zero mean and unitary standard deviation over the entire sample, but country means may be different from zero (see figure 5 and table B7 in the Appendix B). In addition, these factors are clearly trended, since most of the original variables register the sequence of events connected to educational reforms. On the other side, the inclusion of country fixed effect would clean away any country difference in the political orientation of the electorates, which on the contrary we would like to retain in the explanatory power of our data. For these reasons, we have tried two alternative specifications.

$$
R_{c t}=\eta+\varphi \cdot W_{c t}+\zeta \cdot Z_{c t}+\delta_{c}+\delta_{t}+\tau \cdot \delta_{c}+\varepsilon_{c t}
$$

where $c$ and $t$ denote country and year respectively, $R_{c t}$ is our outcome of interest (the factor extracted from the reform variables), $W_{c t}$ is the political orientation of either the cabinet or the parliament in office, $Z_{c t}$ are potentially confounding factors controlling against the risk of spurious 
correlation (GDP per capita at PPP US 2005 dollars, share of public expenditure on GDP), $\delta_{c}$ and $\delta_{t}$ are country and year fixed effects and $\tau \cdot \delta_{c}$ is a country specific time trend. Finally $\varepsilon_{c t}$ is the stochastic error term.

Equation (5) is estimated using OLS and robust correction for heteroscedasticity. Our main results are reported in table 17, while alternative specifications are reported in table B8 in the Appendix $B$. Let us start with noticing that the specification introduced by equation (5) is the most stringent one, because it controls not only for country specific trends (as it is done in table B8 in the Appendix B) but also for country and year fixed effects. This means that the effects of political inclination of parliament are captured by unpredictable variations in the preference of the electorate exercising their voting rights. From this table we observe that educational reforms that we classified as inclusive (since they increase the mean educational attainment and reduce its dispersion, thus raising the bottom tail of the years of education distribution) are negatively correlated with a right wing attitude of parliaments. This is mostly true for the compulsory factor and, at a lesser extent for the comprehensive factor, while the association with the factors correlated to financing college attendance is positive. On the contrary, selective/restrictive policies exhibit positive correlation with right-wing parliaments (all but the accountability factor). This is mostly clearly visible once we consider the partition of reform variables in two groups, where two latent factors are extracted (columns 5 and 9). In this case it is clear that political orientation of the parliament matters for the type of educational policies introduced. The other regressors suggest that inclusive educational are more likely in richer countries/periods, given the positive association per-capita income, while public expenditure in value added seems to favour reforms.

The parliament ideological orientation displays the strongest correlation with reform activity in the educational field. When we consider the cabinet orientation, we do find much weaker correlations. Only if we exclude confounding factors and country/year fixed effects (as done in table B8 in Appendix B), we find partial support to the idea that left-wing executives sponsor inclusive policies, while right-wing ones are more inclined towards selective or restrictive policies. Policy orientation of the cabinet and policy complexion behave in similar ways, despite the former being slightly more statistically correlated with reform factors. Finally, we do not find a stable pattern of government strength in parliament, especially when we control for confounding factors.

Despite the large set of controls we have introduced in table 17, we do not claim the existence of causality links between electoral outcomes and reforming activity of governments, since reversal causality is a real issue in this type of analysis (that is, people may vote following promises that are implemented later on). However, finding significant correlations with ideological inclinations of parliament reinforces our claim that the reforming activity variables are truly exogenous for individual educational choices, and therefore they matter in shaping the distribution of educational attainment in the populations. 
Table 17: Educational reform and political variables - OLS - 1950-2000

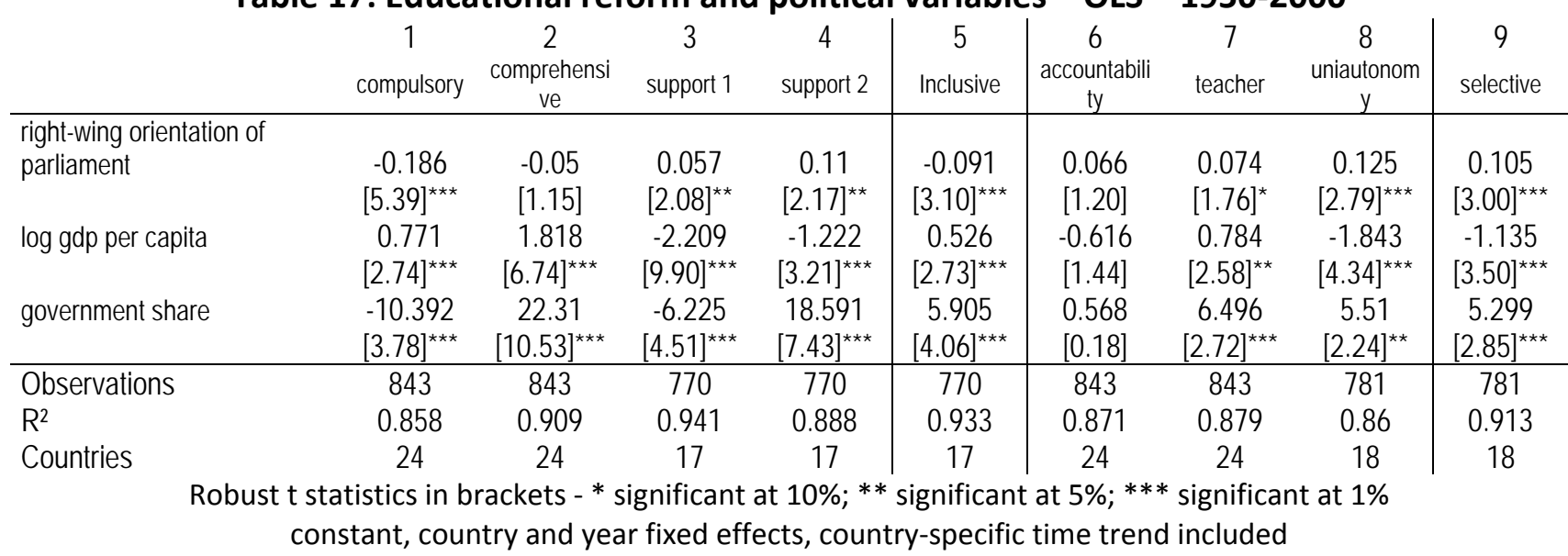

\section{Conclusions}

In the present paper we have shown that reforming the educational systems induces variation in the educational investment on the corresponding populations. By collecting detailed information on different dimensions of the institutional design (from compulsoriness to tracking, from accountability to selectivity, from financial support to autonomy) we have exploited cross-country and temporal variations to assess their causal impact on the (average) educational attainment of the populations affected.

We have paid attention to the distributional aspects of the reforms, since each reform is affecting costs and/or benefits which are heterogeneous in the population, given unobservable ability and difference in parental background. We have noticed that some reforms affect the mean achievement by raising the bottom tail of the distribution, while others enhance the upper tail. Combining the results obtained about the reforms' impacts on mean achievement as well as on educational inequality, we have proposed a classification of the reforms along two dimensions, identifying two main groups: inclusive and selective reforms (the restrictive being a subgroup of the latter).

The robustness and usefulness of this classification is then checked by aggregating single reforms in synthetic indices and studying their impact on mean and dispersion of educational attainment, finding that inclusive policies mostly consists of interventions on the length of compulsory education, on the comprehensiveness of the design and on facilitating the access to tertiary education. More difficult is the exact delimitation of the boundaries of selective policies, since any improvement in the quality (of teacher, of testing and/or selecting students, of making schools and/or universities more accountable) affects both tails of the distribution, leaving uncertain the overall impact on the mean.

These reforms were introduced as output of parliamentary activity. We have investigated the potential existence of correlations between the political orientation of parliaments and/or government in office, in order to establish whether the orientation of educational policies was a reflection of ideological (or strategic) concerns of parties. We find that inclusive policies were favoured by left-wing parliament, while selective policies were promoted in more conservative parliaments. 
With all possible caveats about conducting this exercise, we believe that our result bring in a clear message: despite market incentives (which we do not explicitly model in this paper, leaving to fixed effects to take care of) in educational investments, schooling can be affected by policy makers, who may alter both the level and the distribution. This fall-back both on the economy, via the impact of human capital accumulation on growth, and on the society, via the impact on political participation and social cohesion. This is our program for future research. 


\section{References}

Aakvik, A., Salvanes, K.G. and Vaage, K. (2010): "Measuring heterogeneity in the returns to education using an education reform," European Economic Review, 54(4): 483-500.

Aghion, Philippe, Mathias Dewatripont, Caroline Hoxby, Andreu Mas-Colell and André Sapir. (2010), "The Governance and Performance of Universities: Evidence from Europe and the U.S." Economic Policy January, 9-59

Algan, Yann, Pierre Cahuc and Andrei Shleifer. 2011. "Teaching practices and social capital." NBER Working Paper 17527

Allen, R. (2007): "Allocating pupils to their nearest school: the consequences for ability and social stratification", Urban Studies, 44(4): 751-770.

Ammermüller, A. (2005): "Educational Opportunities and the Role of Institutions", ZEW Discussion Paper, No. 05-44.

Angrist, J.D. and Krueger, A.B (1991): "Does Compulsory School Attendance Affect Schooling and Earnings?," The Quarterly Journal of Economics, 106: 979-1014.

Barro, R. and Lee, J.W.(2010): "A new data set of educational attainment in the world, 1950-2010." NBER Working Papers 15902, National Bureau of Economic Research, Inc.

Bauer, P.C. and Riphahn, R.T (2009): "Kindergarten enrolment and the intergenerational transmission of education." Discussion papers 4466, Institute for the Study of Labor (IZA), Bonn.

Berlinski, S. Galiani, S. and Gertler, P. (2009): "The effect of pre-primary education on primary school performance," Journal of Public Economics, 93(1-2): 219-234.

Bertola, Giuseppe and Andrea Ichino. (1995). Crossing the River: A Comparative Perspective on Italian Employment Dynamics. Economic Policy, Vol. 10(21): 359-420

Bertola, Giuseppe, and Daniele Checchi. (2010). Introduction to a special issue on "University Reform and the Labour Market in Italy", Giornale degli Economisti 69(3):

Bishop, J.H. (1997). "The effect of national standards and curriculum-based exams on achievement". American Economic Review 87: 260-264.

Bishop, J.H. (2006). "Drinking from the Fountain of Knowledge: Student Incentive to Study and Learn", in Eric A. Hanushek, Finis Welch (eds.), Handbook of the Economics of Education. Amsterdam: North-Holland.

Black, S.E. and Devereux, P.J. (2010): "Recent Developments in Intergenerational Mobility", NBER Working Papers, No 15889, National Bureau of Economic Research, Inc.

Bol, Thijs and Herman van Werfhorst. (2011). Measuring Educational Institutional Diversity: External Differentiation, Vocational Orientation and Standardization. mimeo

Brady, D. (2003) The Politics of Poverty: Left Political Institutions, the Welfare State, and Poverty. Social Forces 82(2): 557-588.

Bratti, Massimiliano, Daniele Checchi and Antonio Filippin. (2011). "Should you compete or cooperate with your classmates ?". Education economics, 19(3): 275-289

Breen, Richard and Jan Jonsson. 2007. Explaining Change in Social Fluidity: Educational Equalization and Educational Expansion in Twentieth-Century Sweden. The American Journal of Sociology, Vol. 112(6): 1775-1810

Brunello, G. and Checchi, D. (2007): "Does School Tracking Affect Equality of Opportunity? New International Evidence", Economic Policy, 22: 781-861

Brunello, G., Fort, M. and Weber, G. (2009): "Changes in Compulsory Schooling, Education and the Distribution of Wages in Europe," Economic Journal, 119(536): 516-539.

Card, D. (1999): "The Causal Effect of Education on Earnings", in: Ashenfelter, O., Card, D. (eds.), Handbook of Labor Economics, Volume 3A: 1801-1863. Amsterdam: North-Holland. 
Card, David, and Jesse Rothstein. (2007). "Racial Segregation and the Black-White Test Score Gap." Journal of Public Economics 91: 2158-84.

Carneiro, P. and Heckman, J. J. (2002), 'The evidence on credit constraints in post-secondary schooling', Economic Journal 112(482), 705-734.

Carneiro, P. and J. J. Heckman. (2003): "Human Capital Policy". In Inequality in America: What Role for Human Capital Policies ?, by J. J. Heckman, A. B. Krueger, and B. M. Friedman (eds). Cambridge, MA: MIT Press, 2003, 77-239.

Causa, O. and C. Chapuis (2009), "Equity in Student Achievement Across OECD Countries: An Investigation of the Role of Policies." OECD Economics Department Working Papers, No. 708, OECD

Chapman, Bruce and Mathias Sinning. (2011). Student Loan Reforms for German Higher Education: Financing Tuition Fees. IZA Discussion Paper No. 5532, February

Chapman, Bruce, (1997). Conceptual Issues and the Australian Experience with Income Contingent Charges for Higher Education. Economic Journal, vol. 107(442): 738-51, May

Chapman, Bruce, (2006). Income Contingent Loans for Higher Education: International Reforms. in Erik Hanushek and F. Welch (ed.), 2006. Handbook of the Economics of Education, Elsevier, volume 2(2): 1435-1503

Checchi, D. (2004): “Does educational achievement help to explain income inequality ?" chapter 4 in A.Cornia (ed), Inequality, Growth and Poverty in an Era of Liberalization and Globalization. Oxford University Press

Cunha, F. and Heckman, J.J. (2009): "The Economics and Psychology of Inequality and Human Development," Journal of the European Economic Association, 7(2-3): 320-364, 04-05.

Cunha, F. and Heckman, J.J., (2007): "The Technology of Skill Formation", American Economic Review 97(2): 31-47

Cunha, F., and Heckman, J.J (2008): "Formulating, Identifying and Estimating the Technology of Cognitive and Noncognitive Skill Formation," Journal of Human Resources, 43(4).

Cunha, F., Heckman, J.J, Lochner, L., Masterov, D.V (2006): "Interpreting the Evidence on Life Cycle Skill Formation" (Ch. 12) in: Hanushek, E.A, Welch, F. (eds.), Handbook of the Economics of Education, Amsterdam: North-Holland, pp. 697-812.

Currie, J. (2001): "Early Childhood Education Programs", Journal of Economic Perspectives, 15(2): 213-238.

Dearden, Lorraine, Emla Fitzsimons and Gill Wyness. (2011). The impact of tuition fees and support on university participation in the UK. CEE DP 126

Dearden, Lorraine, Emla Fitzsimons, Alissa Goodman and Greg Kaplan. (2008). Higher education funding reforms in England: The distributional effects and the shifting balance of costs. The Economic Journal, 118 (February), F100-F125.

Dee, Thomas S. 2004. "Are There Civic Returns to Education?" Journal of Public Economics 88: 1697-720.

Dobkin, Carlos and Fernando Ferreira (2010). Do school entry laws affect educational attainment and labor market outcomes? Economics of Education Review 29 (2010) 40-54

Dolton, P. and Marcenaro-Gutierrez, O.D. (2011): "If you pay peanuts do you get monkeys? A cross-country analysis of teacher pay and pupil performance," Economic Policy, 26(65): 555, January.

Döring, Holger and Manow, Philip. 2010. Parliament and government composition database (ParlGov): An infrastructure for empirical information on political institutions - Version 10/02 - http://www.parlgov.org

Dustmann, C. (2004): "Parental Background, Secondary School Track Choice and Wages", Oxford Economic Papers, 56: 209-230 
Esping-Andersen, G. (2004), "Unequal opportunities and the mechanisms of social inheritance", Chapter 12 in M. Corak, (ed), Generational Income Mobility in North America and Europe, Cambridge University Press.

Eurydice (2008). Higher Education Governance in Europe. Policies, structures, funding and academic staff. Brussels

Fiske, E. and H.Ladd 2000. When school compete - a cautionary tale. Brookings Institution Press, Washington DC.

Földvári, P., and B. Van Leeuwen. (2011). "Should Less Inequality in Education Lead to a More Equal Income Distribution?" Education Economics, v. 19(5): 537-554.

Freeman, Richard, Stephen Machin and Martina Viarengo. (2010). Variation in educational outcomes and policies across countries and of schools within countries. NBER WP.16293

Fuchs, T. and Woessmann,L. (2007). "What accounts for international differences in student performance? A re-examination using PISA data," Empirical Economics, Springer, vol. 32(2): 433-464

Galindo-Rueda, F. and Vignoles, A. (2004): "The Heterogeneous Effect of Selection in Secondary Schools: Understanding the Changing Role of Ability," IZA Discussion Papers 1245, Institute for the Study of Labor (IZA).

Gibbons, S. and Silva, O. (2006): "Competition and accessibility in school markets: empirical analysis using boundary discontinuities", in: Gronberg, T.J. and Jansen, D.W., (eds.) "Improving school accountability: check-ups or choice. Advances in applied microeconomics" (Ch. 14). Elsevier, Oxford, UK, pp. 157-184

Goodman, A. and Sianesi, B. (2005): "Early education and children's outcomes: low long do the impacts last?," Fiscal Studies, Institute for Fiscal Studies, vol. 26(4): 513-548.

Gorard, S., Taylor, C. and Fitz, J., (2003): Schools, Markets and Choice Policies. Routledge-Farmer, London.

Gradstein M. and M.Justman. 1999. The Industrial Revolution, Political Transition, and the Subsequent Decline in Inequality in 19th-Century Britain. Explorations in Economic History. Vol. 36 (2). p 109-27

Grossman, M. (2006): “Education and Nonmarket Outcomes", in: Hanushek, E.A, Welch, F. (eds.), Handbook of the Economics of Education. Amsterdam: North-Holland.

Hanushek, E.A. (2010): "The economic value of higher teacher quality" NBER Working Papers 16606, National Bureau of Economic Research

Hanushek, E.A. and Kimko, D.D. (2000): "Schooling, Labor-Force Quality, and the Growth of Nations", American Economic Review 90 (5): 1184-1208.

Hanushek, E.A. and Raymond, M.F (2005): "Does School Accountability Lead To Improved Student Performance?," Journal of Policy Analysis and Management, 24(2): 297-327.

Hanushek, E.A. and Rivkin, S. G. (2006): "Teacher quality," in E. A. Hanushek, and F. Welch (eds) Handbook of the Economics of Education, vol. 1, pp. 1050-1078. North Holland, Amsterdam.

Hanushek, E.A. and Woessmann, L. (2006): "Does Educational Tracking Affect Performance and Inequality? Differences- in-Differences Evidence Across Countries," Economic Journal, vol. 116(510): C63-C76

Hanushek, E.A. and Woessmann, L. (2010): "The Economics of International Differences in Educational Achievement," NBER Working Papers 15949, National Bureau of Economic Research, Inc.

Hanushek, E.A., and Raymond, M.F (2003). "Lessons about the Design of State Accountability Systems", in: Paul E. Peterson and Martin R. West (eds). No Child Left Behind? The Politics and Practice of Accountability, Washington, DC: Brookings: 127-151. 
Hanushek, E.A., and Raymond, M.F. (2004): "The effect of school accountability systems on the level and distribution of student achievement", Journal of the European Economic Association 2, 2-3: 406-415.

Hanushek, E.A., and Woessmann, L. and Lei Zhang (2011). General Education, Vocational Education, And Labor-Market Outcomes Over The Life-Cycle. NBER Working Paper 17504

Harmon, C. and Walker, I. (1995): "Estimates of the Economic Return to Schooling for the United Kingdom", American Economic Review, 85: 1278-1286.

Harmon, C., Oosterbeek, H. and Walker, I. (2003): "The Returns to Education: Microeconomics", Journal of Economic Surveys 17 (2): 115-155.

Hicks, A. and Swank, D.H. (1992) "Politics, Institutions, and Welfare Spending in Industrialized Democracies, 1960-82." American Political Science Review 86: 658-74.

Holmlund, Helena (2008). A researcher's guide to the Swedish compulsory school reform. CEE DP, 87. Centre for the Economics of Education, London School of Economics and Political Science, London, UK.

Hoxby, C. (2000a): "Does Competition Among Public Schools Benefit Students and Taxpayers?", American Economic Review 90: 1209-38.

Hoxby, C. (2000b). Peer Effects in the Classroom: Learning from Gender and Race Variation. NBER Working Papers 7867, National Bureau of Economic Research

Hoxby, C., (2003): "School Choice and School Productivity (Or, Could School Choice be a Rising Tide that Lifts All Boats?)", in: Hoxby, C. (ed.), The Economics of School Choice. University of Chicago Press, Chicago.

Hoxby, Caroline M. (2009). "The Changing Selectivity of American Colleges." Journal of Economic Perspectives, 23(4): 95-118

Jacob, B. (2005): "Accountability, Incentives and Behavior: Evidence from School Reform in Chicago." Journal of Public Economics, 89(5-6): 761-796

Jacobs, B. and F. Van der Ploeg, 2006. "Guide To Reform Of Higher Education: A European Perspective." Economic Policy, Vol. 21, No. 47, pp. 535-592.

Jürges, H., Schneider, K. and Büchel, F. (2005): "The Effect Of Central Exit Examinations On Student Achievement: Quasi-Experimental Evidence From TIMSS Germany," Journal of the European Economic Association, 3(5): 1134-1155.

Korpi, W. and Palme, J. (2003) New Politics and Class Politics in the Context of Austerity and Globalization: Welfare State Regress in 18 Countries, 1975-1995. American Political Science Review 97(3): 425-446.

Krueger, A.B. (1999): "Experimental estimates of education production functions," Quarterly Journal of Economics, 114, 497-532.

Krueger, A.B., Lindahl, M. (2001): "Education for Growth: Why and For Whom?" Journal of Economic Literature 39(4): 1101-1136.

Krueger, A.B., Lindahl, M. (2009): “An Evaluation of Selected Reforms to Education and Labor Market Policy in Sweden", Studier i finanspolitik, vol.4: 5-40

Ladd, H.F., Walsh, R.P. (2002): "Implementing Value-Added Measures of School Effectiveness: Getting the Incentives Right", Economics of Education Review 21 (1): 1-17.

Lavy, Victor. 2011. Do Differences in School's Instruction Time Explain International Achievement Gaps in Maths, Science and Language? Evidence from Developed and Developing Countries CEE DP 118

Lazear, E. 2003. Teacher incentives. Swedish Economic Policy Review 10: 179-214

Leschinsky, A. and K. Mayer (eds). 1990. The comprehensive school experiment revisited: Evidence from Western Europe. Verlang Peter Lang.

Leuven, E., Lindahl, M., Oosterbeek, H. and Webbink, D. (2010) "Expanding schooling opportunities for 4-year-olds," Economics of Education Review, 29(3): 319-328. 
Lochner, Lance and Alexander Monge-Naranjo. (2011) Credit Constraints in Education. NBER Working Paper No. 17435, September

Lochner, Lance and Enrico Moretti, (2004). "The Effect of Education on Crime: Evidence from Prison Inmates, Arrests, and Self-Reports," American Economic Review, vol. 94(1): 155-189.

Mandel, Philipp and Bernd Süssmuth (2011). Total Instructional Time Exposure and Student Achievement: An Extreme Bounds Analysis Based on German State-Level Variation. CESifo Working Paper No. 3580

Manning, A. and Pisckhe, J.S. (2006). Comprehensive versus Selective Schooling in England in Wales: What Do We Know?. IZA Discussion Paper n.2072

Meghir, C. and C. Palme, M. (2005): "Educational Reform, Ability, and Family Background," American Economic Review, 95(1): 414-424.

Meghir, C. and S.G.Rivkin. (2010). "Econometric Methods for Research in Education". NBER Working Paper No. 16003, May

Meschi E. and Scervini F. (2010): "A new dataset of educational inequality", GINI discussion paper 3, AIAS, Amsterdam.

Milligan, K., Moretti, E., Oreopoulos, P., (2004). "Does education improve citizenship? Evidence from the United States and the United Kingdom." Journal of Public Economics 88: 16671695

Moller, S., Huber, E., Stephens, J.D., Bradley, D. and Nielsen, F. (2003) Determinants of Relative Poverty in Advanced Capitalist Democracies. American Sociological Review 68(1): 22-51.

Morrisson, C., and F. Murtin. (2010). "The Kuznets Curve of Education: A Global Perspective on Education Inequalities" Centre for the Economics of Education, London School of Economics, CEE DP 116.

Moulton, B.R. (1990): "An Illustration of a Pitfall in Estimating the Effects of Aggregate Variables on Micro Units", The Review of Economics and Statistics, 72(2): pp. 334-338

Murtin, F. and Viarengo, M. (2011): "The Expansion and Convergence of Compulsory Schooling in Western Europe, 1950-2000", Economica, Vol. 78(311): 501-522.

Nicoletti, G., S. Scarpetta and O. Boylaud, (2000). "Summary indicators of product market regulation with an extension to employment protection legislation", OECD, Working Papers n. 226

OECD (2004a). Employment protection regulation and labour market performance, Economic Outlook, Chapter 2, Paris.

OECD (2004b), Wage setting institutions and outcomes, Economic Outlook, Chapter 3, Paris

OECD (2005). Teachers matter. Attracting, developing and retaining effective teachers. Paris.

OECD (2007). No More Failures: Ten Steps to Equity in Education. OECD, Paris.

OECD (2010). A Family Affair: Intergenerational Social Mobility across OECD Countries, chpt.5 of Economic Policy Reforms. Going for Growth. Paris

Oliveira Martins, Joaquim, Romina Boarini, Hubert Strauss, Christine de la Maisonneuve and Clarice Saadi. (2007). The policy determinants of investment in tertiary education. OECD Economics Department WORKING PAPERS No. 576

Oreopoulos, P. and K.Salvanes. (2011). Priceless: The Nonpecuniary Benefits of Schooling. Journal of Economic Perspectives, 25(1): 159-184

Oreopoulos, Philip. (2007). Do Dropouts Drop Out Too Soon? Wealth, Health, and Happiness from Compulsory Schooling. Journal of Public Economics 91, (11-12): 2213-2229.

Pekkarinen, Tuomas, Roope Uusitalo and Sari Pekkala (2006), "Education Policy and Intergenerational Income Mobility: Evidence from the Finnish Comprehensive School Reform", IZA Discussion Paper No. 2204.

Pischke, J.S and von Wachter, T. (2008): "Zero Returns to Compulsory Schooling in Germany: Evidence and Interpretation," The Review of Economics and Statistics, 90(3): 592-598, 06. 
Rivkin, S. G., Hanushek, E.A., and Kain, J. F. (2005): "Teachers, Schools and Academic Achievement," Econometrica, 73(2), 417-458.

Rothstein, J.M. (2006): "Good Principals or Good Peers? Parental Valuation of School Characteristics, Tiebout Equilibrium, and the Incentive Effects of Competition among Jurisdictions," American Economic Review, 96(4): 1333-1350

Rouse, C.E. and Barrow, L. (2009): "School vouchers and student achievement: Recent evidence and remaining questions." Annual Review of Economics 1: 17-42.

Schuetz, G., Ursprung, H. and Woessmann, L. (2008): "Education Policy and Equality of Opportunity," Kyklos, vol. 61(2): 279-308.

Schuetz, G., West, M. and Woessmann, L. (2007): "School Accountability, Autonomy, Choice, and the Equity of Student Achievement: International Evidence from PISA 2003", Education Working Paper No. 14, OECD, Paris.

Shavit, Yossi, Eyal Bar Haim, and Hanna Ayalon. (2009). Expansion and inequality of educational opportunity: a comparative study. mimeo

Teichler, U. (2007). Higher education systems. Conceptual frameworks, comparative perspectives, empirical findings. Taipe, Rotterdam

Thomas, V., Wang, Y. and Fan, X. (2001): "Measuring Education Inequality: Gini Coefficients of Education", World Bank Policy Research Working Paper No. 2525.

Vandenberghe, V. (2006). "Achievement Effectiveness and Equity. The role of Tracking, Grade Repetition and Inter-school Segregation" Applied Economics Letters, vol. 13(11): 685-693.

Waldvogel, J. (2002): "Child care, women's employment, and child outcomes", Journal of Population Economics, 15(3): 527-48

West, M.R. and Woessmann, L. (2010): " 'Every Catholic Child in a Catholic School': Historical Resistance to State Schooling, Contemporary Private Competition, and Student Achievement across Countries," Economic Journal, 120(546): F229-F255.

Woessmann, L. (2003): "Schooling Resources, Educational Institutions and Student Performance: the International Evidence," Oxford Bulletin of Economics and Statistics, vol. 65(2): 117170, 05.

Woessmann, L. (2005): "The effect heterogeneity of central examinations: evidence from TIMSS, TIMSS-Repeat and PISA" Education Economics 13(2): 143-169.

Woessmann, L. (2007). "International Evidence on School, Competition, Autonomy and Accountability: a Review”. Peabody Journal of Education, vol. 82(2-3): 473-497.

Woessmann, L. (2008): "Efficiency and equity of European education and training policies," International Tax and Public Finance, vol. 15(2): 199-230

Woessmann, L. and West, M. (2006). "Class-size effects in school systems around the world: Evidence from between-grade variation in TIMSS," European Economic Review, vol. 50(3): 695-736

Woessmann, L., Lüdemann, E., Schütz, G. and West, M.R (2009). School Accountability, Autonomy, and Choice, around the world. Edward Elgar

Woldendorp, Jaap, Hans Keman and Ian Budge (2000). Party government in 48 democracies (19451998), Kluwer 


\section{Appendix A \\ Sources of information on institutional features of education systems}

\begin{tabular}{|c|c|}
\hline REFORM & SOURCES \\
\hline Pre - primary expansion & $\begin{array}{l}\text { - Eurydice: National Education System Descriptions (Section 3) } \\
\text { - Garrouste (2010) }\end{array}$ \\
\hline Pre - primary compulsory & $\begin{array}{l}\text { - Eurydice: National Education System Descriptions (Section 2,3) } \\
\text { - Garrouste (2010) }\end{array}$ \\
\hline $\begin{array}{l}\text { Duration compulsory } \\
\text { education }\end{array}$ & $\begin{array}{l}\text { - Eurydice: National Education System Descriptions (Section 2,4,5) } \\
\text { - Garrouste (2010) } \\
\text { - Brunello, Fort and Weber (2009) }\end{array}$ \\
\hline Entry age & $\begin{array}{l}\text { - Eurydice: National Education System Descriptions (Section 2,3,4) } \\
\text { - Garrouste (2010) } \\
\text { - Brunello, Fort and Weber (2009) }\end{array}$ \\
\hline Leaving age & $\begin{array}{l}\text { - Eurydice: National Education System Descriptions (Section 2,4,5) } \\
\text { - Garrouste (2010) } \\
\text { - Brunello, Fort and Weber (2009) }\end{array}$ \\
\hline Tracking age & $\begin{array}{l}\text { - Eurydice: National Education System Descriptions (Section 2,4,5) } \\
\text { - Garrouste (2010) }\end{array}$ \\
\hline Expansion of university access & $\begin{array}{l}\text { - Eurydice: National Education System Descriptions (Section 6) } \\
\text {-Garrouste (2010) } \\
\text { - Eurydice (1999): “Key Topics in Education, Volume 1, Financial Support for Students in Higher Education } \\
\text { in Europe” } \\
\text { - Eurydice (2000) "Two Decades of Reform in Higher Education in Europe: } 1980 \text { Onwards" }\end{array}$ \\
\hline Increase grant size & - Eurydice (2000) "Two Decades of Reform in Higher Education in Europe: 1980 Onwards" \\
\hline $\begin{array}{l}\text { Loan component to grant } \\
\text { component }\end{array}$ & - Eurydice (2000) "Two Decades of Reform in Higher Education in Europe: 1980 Onwards" \\
\hline Interest rate & - Eurydice (2000) "Two Decades of Reform in Higher Education in Europe: 1980 Onwards" \\
\hline $\begin{array}{l}\text { Pre-primary school teacher } \\
\text { qualification }\end{array}$ & - Eurydice: National Education System Descriptions (Section 8) \\
\hline $\begin{array}{l}\text { Primary school teacher } \\
\text { qualification }\end{array}$ & - Eurydice: National Education System Descriptions (Section 8) \\
\hline $\begin{array}{l}\text { Secondary school teacher } \\
\text { qualification }\end{array}$ & - Eurydice: National Education System Descriptions (Section 8) \\
\hline School evaluation & $\begin{array}{l}\text { - Eurydice: National Education System Descriptions (Section 9) } \\
\text { - Eurydice (2004): "Evaluation of Schools Providing Compulsory Education In Europe" thematic study }\end{array}$ \\
\hline $\begin{array}{l}\text { Standardised test (for career } \\
\text { advancement) }\end{array}$ & - Eurydice (2009): “National Testing of Pupils in Europe: Objectives, Organisation and Use of Results" \\
\hline $\begin{array}{l}\text { Standardised test (for other } \\
\text { purposes) }\end{array}$ & - Eurydice (2009): “National Testing of Pupils in Europe: Objectives, Organisation and Use of Results" \\
\hline Selectivity in university access & $\begin{array}{l}\text { - Eurydice (1999): "Key Topics in Education, Volume 1, Financial Support for Students in Higher Education } \\
\text { in Europe" }\end{array}$ \\
\hline School autonomy & - Eurydice (2008) "School Autonomy in Europe Policies and Measures" \\
\hline Teacher autonomy & - Eurydice (2008) "Levels of Autonomy and Responsibilities of Teachers in Europe" \\
\hline Index of university autonomy & - Eurydice (2000) "Two Decades of Reform in Higher Education in Europe: 1980 Onwards" (p. 91) \\
\hline
\end{tabular}

\section{Sources of information on Institutional Features of school systems: References}

\section{Cross-country sources:}

- Brunello, G., Fort, M. and Weber, G. (2009): Technical Appendix to "Changes in Compulsory Schooling, Education and the Distribution of Wages in Europe," Economic Journal, 119(536): 516$539,03$.

- Eurybase - Descriptions of National Education Systems and Policies http://eacea.ec.europa.eu/education/eurydice/eurybase en.php\#description

- Eurydice (1999): "Key Topics in Education, Volume 1, Financial Support for Students in Higher Education in Europe", http://www.eric.ed.gov/PDFS/ED442314.pdf

- Eurydice (2000) "Two Decades of Reform in Higher Education in Europe: 1980 Onwards", Eurydice Thematic Studies, http://www.mp.gov.rs/resursi/dokumenti/dok174-eng Reform higher.pdf 
- Eurydice (2004): "Evaluation of Schools Providing Compulsory Education In Europe" http://eacea.ec.europa.eu/eurydice/ressources/eurydice/pdf/0 integral/042EN.pdf

- Eurydice (2008) "School Autonomy in Europe Policies and Measures", Eurydice thematic studies http://eacea.ec.europa.eu/education/eurydice/documents/thematic reports/090EN.pdf

- Eurydice (2009): "National Testing of Pupils in Europe: Objectives, Organisation and Use of Results", Eurydice thematic studies http://eacea.ec.europa.eu/education/eurydice/documents/thematic reports/109EN.pdf

- Fort, M. (2006): “Educational reforms across Europe: a toolbox for empirical research", unpublished paper, available at http://www2.dse.unibo.it/fort/files/papers/fort reforms.pdf

- Garrouste, Christelle (2010): "100 Years of Educational Reforms in Europe: a contextual database" JRC Scientific and Technical Reports, EUR 24487, Luxembourg: Publications Office of the European Union http://publications.jrc.ec.europa.eu/repository/bitstream/111111111/14920/1/reqno jrc57357.pd $\underline{f}$

\section{Country-specific sources:}

- Aakvik, A., Salvanes, K.G. and Vaage, K. (2010): "Measuring heterogeneity in the returns to education using an education reform," European Economic Review, 54(4): 483-500.

- Adamski, W. and I. Bialecki (1981): "Selection at School and Access to Higher Education in Poland", European Journal of Education, 1: 209-223.

- Antonowicz, D. and Simonová, N. (2006): "Czech and Polish Higher Education - from Bureaucracy to Market Competition". Czech Sociological Review, 03: 517-536

- Björklund, A., Per-Anders, E., Freriksson, P. and Krueger, A.B. (2004): "Education, Equality and Efficiency: An Analysis of Swedish School Reforms during the 1990s." IFAU Report n.1, Uppsala, Institute for Labour Market Policy Evaluation

- Duczmal, W. (2007): "Poland" in: James J.F. Forest and Philip G. Altbach (eds.), International Handbook of Higher Education, 935-949.

- Guyon, N., Maurin, E. and McNally, S. (2010): "The Effect of Tracking Students by Ability into Different Schools: a Natural Experiment," CEPR Discussion Papers N. 7977, C.E.P.R., London.

- Jakubowski, M., Patrinos, H.A., Porta, E.E. and Wiśniewski, J. (2010): "The Impact of the 1999 Education Reform in Poland," OECD Education Working Papers, No. 49.

- Jung-Miklaszewska, J. "The system of Education in the republic of Poland", document published by the Bureau for Academic Recognition and International Exchange, http://www.buwiwm.edu.pl

- Machin, S. and Vignoles, A. (2005): "Education Policy in the UK," CESifo DICE Report, Ifo Institute for Economic Research at the University of Munich, vol. 3(4): 64-74, 01

- Meghir, C. and Palme, M. (2003): "Ability, parental background and education policy: empirical evidence from a social experiment", Institute of Fiscal Studies, Working Paper, WP03/05.

- Meghir, C. and Palme, M. (2005): "Educational reform, ability, and family background", American Economic Review, 95(1): 414-24.

- Sahlberg, P. (2007) Education policies for raising student learning: the Finnish approach, Journal of Education Policy, Vol. 22(2): 147-171 


\section{Appendix B}

Table B1: Number of observations per country from the four data sources

\begin{tabular}{|c|c|c|c|c|c|}
\hline Country & ESS & EUSILC & IALS & ISSP & Total \\
\hline Austria & 4888 & 5548 & n.a. & 1358 & 11794 \\
\hline Belgium FL & 3456 & 3387 & 1373 & n.a. & 8216 \\
\hline Belgium FR & 1462 & 1609 & n.a. & n.a. & 3071 \\
\hline Czech Republic & 5015 & 4868 & 2536 & 3094 & 15513 \\
\hline Denmark & 4760 & 2524 & 2420 & n.a. & 9704 \\
\hline Estonia & 3129 & 3611 & n.a. & n.a. & 6740 \\
\hline Finland & 6339 & 5204 & 2269 & n.a. & 13812 \\
\hline France & 5278 & 8074 & n.a. & 1422 & 14774 \\
\hline Great Britain & 5807 & 4360 & 2673 & n.a. & 12840 \\
\hline Germany & 8424 & 11542 & 1453 & 5367 & 26786 \\
\hline Greece & 5411 & 6778 & n.a. & n.a. & 12189 \\
\hline Hungary & 4970 & 7909 & 1949 & 3439 & 18267 \\
\hline Ireland & 5464 & 4151 & 1599 & 688 & 11902 \\
\hline Italy & 2181 & 26854 & 2404 & n.a. & 31439 \\
\hline Latvia & 1020 & 2829 & n.a. & 894 & 4743 \\
\hline Netherlands & 6018 & 4105 & 2346 & n.a. & 12469 \\
\hline Northern Ireland & 197 & n.a. & 2032 & n.a. & 2229 \\
\hline Norway & 5404 & n.a. & 2391 & 902 & 8697 \\
\hline Poland & 5217 & 21696 & 2238 & 4290 & 33441 \\
\hline Portugal & 6192 & 4957 & n.a. & 979 & 12128 \\
\hline Slovak Republic & 3819 & 7626 & n.a. & 833 & 12278 \\
\hline Slovenia & 4053 & 3917 & 1978 & 3203 & 13151 \\
\hline Spain & 5474 & 16389 & n.a. & 855 & 22718 \\
\hline Sweden & 5437 & 1957 & 1931 & 876 & 10201 \\
\hline Total & 109415 & 159895 & 31592 & 28200 & 329102 \\
\hline
\end{tabular}


Table B2: Exogeneity of reforms

\begin{tabular}{lcccc}
\hline & \multicolumn{3}{c}{ Mean year of education (5 lags) } \\
\cline { 2 - 5 } & Coefficient & $\begin{array}{c}\text { Robust } \\
\text { standard } \\
\text { error }\end{array}$ & Obs. & $R^{2}$ \\
\hline Pre-primary expansion & -0.002 & {$[0.002]$} & 3476 & 0.647 \\
Pre-primary teacher qualification & 0.002 & {$[0.002]$} & 3476 & 0.556 \\
Beginning age of compulsory education & 0.001 & {$[0.001]$} & 3476 & 0.973 \\
Leaving age of compulsory education & 0.005 & {$[0.009]$} & 3476 & 0.695 \\
Duration compulsory school & 0.009 & {$[0.009]$} & 3476 & 0.706 \\
Primary teacher qualification & 0.001 & {$[0.002]$} & 3476 & 0.707 \\
Secondary teacher qualification & 0.002 & {$[0.002]$} & 3476 & 0.753 \\
Tracking age & -0.011 & {$[0.012]$} & 3476 & 0.712 \\
Standardised tests (for career advancement) & 0.002 & {$[0.002]$} & 3476 & 0.524 \\
Standardised tests (for other purposes) & -0.001 & {$[0.001]$} & 3476 & 0.311 \\
School evaluation & 0.001 & {$[0.001]$} & 3476 & 0.258 \\
School autonomy & $0.005 * * *$ & {$[0.001]$} & 3476 & 0.571 \\
Teacher autonomy & 0.001 & {$[0.002]$} & 3476 & 0.77 \\
Selectivity in university access & 0.001 & {$[0.003]$} & 2366 & 0.726 \\
Expansion of university access & -0.003 & {$[0.002]$} & 3476 & 0.612 \\
Increase grant size & -0.001 & {$[0.001]$} & 2366 & 0.278 \\
Loan component to grant component & 0.000 & {$[0.001]$} & 2366 & 0.938 \\
Interest rate & 0.001 & {$[0.001]$} & 2366 & 0.962 \\
Index of university autonomy & 0.001 & {$[0.002]$} & 2546 & 0.646 \\
\hline
\end{tabular}

Notes: robust standard errors in brackets - *** $p<0.01, * * p<0.05, * p<0.1$. Each row reports regressions with alternative reforms as dependent variable, regressed on mean years of education in country $c$ at time $t-5$. All regressions control for the share of female and the share of people with graduate parent in each cell; they also include country, cohort, and survey fixed effects. The regressions are weighted by the number of observations in each country-cohort-survey cell. 
Table B3: Separate regressions by datasets

\begin{tabular}{|c|c|c|c|c|c|c|c|c|c|c|c|}
\hline & & $\begin{array}{l}\text { Pre-primary } \\
\text { expansion }\end{array}$ & $\begin{array}{l}\text { Pre-primary } \\
\text { teacher } \\
\text { qualification }\end{array}$ & $\begin{array}{l}\text { Duration } \\
\text { compulsory } \\
\text { school }\end{array}$ & $\begin{array}{l}\text { Beginning } \\
\text { age comp } \\
\text { education }\end{array}$ & $\begin{array}{l}\text { Leaving age } \\
\text { comp } \\
\text { education }\end{array}$ & $\begin{array}{c}\text { Primary } \\
\text { teacher } \\
\text { qualification }\end{array}$ & $\begin{array}{l}\text { Secondary } \\
\text { teacher } \\
\text { qualification }\end{array}$ & Tracking age & $\begin{array}{l}\text { Standardised } \\
\text { tests (for } \\
\text { career adv.) }\end{array}$ & $\begin{array}{l}\text { Standardised } \\
\text { tests (for } \\
\text { other } \\
\text { purposes) }\end{array}$ \\
\hline \multirow[t]{3}{*}{ ESS } & Reform & $0.248^{\star \star \star}$ & $-0.319^{\star \star \star}$ & $0.073^{\star \star \star}$ & 0.211 & $0.078^{\star \star \star}$ & 0.118 & $0.206^{\star \star}$ & -0.004 & -0.081 & $0.185^{\star *}$ \\
\hline & & [0.089] & [0.076] & [0.017] & [0.183] & [0.018] & [0.079] & [0.083] & [0.018] & [0.156] & [0.093] \\
\hline & Obs. & 52586 & 52586 & 52586 & 52586 & 52586 & 52586 & 52586 & 52586 & 52586 & 52586 \\
\hline \multirow[t]{3}{*}{ EUSILC } & Reform & 0.066 & -0.112 & $0.065^{\star \star}$ & $0.404^{\star}$ & $0.072^{\star \star}$ & $0.325^{\star \star \star}$ & 0.106 & -0.004 & -0.471 & $0.583^{\star \star \star}$ \\
\hline & & [0.079] & [0.082] & [0.032] & [0.245] & [0.032] & [0.121] & [0.115] & [0.032] & [0.360] & [0.148] \\
\hline & Obs. & 91359 & 91359 & 91359 & 91359 & 91359 & 91359 & 91359 & 91359 & 91359 & 91359 \\
\hline \multirow[t]{3}{*}{ IALS } & Reform & -0.004 & $-0.312^{\star \star *}$ & 0.043 & $1.288^{\star \star \star}$ & 0.043 & $-0.212^{\star}$ & -0.196 & 0.009 & $0.701^{\star \star \star}$ & -0.004 \\
\hline & & [0.147] & [0.102] & [0.031] & [0.205] & [0.031] & [0.123] & [0.122] & [0.030] & [0.158] & [0.233] \\
\hline & Obs. & 21107 & 21107 & 21107 & 21107 & 21107 & 21107 & 21107 & 21107 & 21107 & 21107 \\
\hline \multirow[t]{4}{*}{ ISSP } & Reform & 0.225 & $-0.324^{\star \star \star *}$ & $-0.087^{\star \star}$ & $-2.601^{\star x \star}$ & $-0.087^{\star \star}$ & $-0.242^{\star}$ & -0.202 & 0.017 & & -0.686 \\
\hline & & [0.157] & [0.107] & [0.038] & [0.319] & [0.038] & [0.130] & [0.165] & [0.037] & & [0.502] \\
\hline & Obs. & 20957 & 20957 & 20957 & 20957 & 20957 & 20957 & 20957 & 20957 & 20957 & 20957 \\
\hline & & $\begin{array}{c}\text { School } \\
\text { evaluation }\end{array}$ & $\begin{array}{l}\text { School } \\
\text { autonomy }\end{array}$ & $\begin{array}{l}\text { Teacher } \\
\text { autonomy }\end{array}$ & $\begin{array}{c}\text { Selectivity } \\
\text { university } \\
\text { access } \\
\end{array}$ & $\begin{array}{c}\text { Expansion } \\
\text { university } \\
\text { access } \\
\end{array}$ & $\begin{array}{l}\text { Increase } \\
\text { grant size }\end{array}$ & $\begin{array}{l}\text { Loan to grant } \\
\text { component }\end{array}$ & Interest rate & $\begin{array}{c}\text { Index of } \\
\text { university } \\
\text { autonomy }\end{array}$ & \\
\hline \multirow[t]{3}{*}{ ESS } & Reform & $-0.449^{\star \star \star}$ & $0.445^{\star \star \star}$ & -0.085 & $-0.204^{\star \star}$ & 0.140 & -0.011 & -0.044 & $-0.330^{\star \star}$ & $-0.677^{x k x}$ & \\
\hline & & [0.126] & [0.161] & [0.146] & [0.093] & [0.086] & [0.115] & [0.149] & [0.165] & [0.255] & \\
\hline & Obs. & 52586 & 52586 & 52586 & 33331 & 52586 & 38346 & 33331 & 33331 & 33331 & \\
\hline \multirow[t]{3}{*}{ EUSILC } & Reform & $-0.904^{\star \star \star}$ & $0.538^{\star}$ & $-0.793^{\star \star \star}$ & -0.143 & 0.149 & 0.222 & 0.441 & 0.097 & $2.886^{\star \star \star}$ & \\
\hline & & [0.162] & [0.286] & [0.194] & [0.129] & [0.094] & [0.182] & [0.318] & [0.366] & [0.432] & \\
\hline & Obs. & 91359 & 91359 & 91359 & 52969 & 91359 & 57837 & 52969 & 52969 & 52969 & \\
\hline \multirow[t]{3}{*}{ IALS } & Reform & & -0.095 & 0.359 & $0.408^{\star \star}$ & 0.098 & 0.137 & 0.141 & 0.457 & & \\
\hline & & & [0.246] & [0.263] & [0.192] & [0.179] & [0.223] & [0.404] & [0.796] & & \\
\hline & Obs. & 21107 & 21107 & 21107 & 12406 & 21107 & 14942 & 12406 & 12406 & 12406 & \\
\hline \multirow[t]{3}{*}{ ISSP } & Reform & & & & $-0.716^{\star \star \star}$ & $-0.530^{\star}$ & 0.424 & -0.027 & $-1.348^{\star \star}$ & $-1.693^{\star \star}$ & \\
\hline & & & & & [0.274] & [0.281] & [0.290] & [0.651] & [0.549] & [0.810] & \\
\hline & Obs. & 20957 & 20957 & 20957 & 6931 & 20957 & 10025 & 6931 & 6931 & 6931 & \\
\hline
\end{tabular}


Table B4: Reforms impact with randomly generated years of birth

\begin{tabular}{|c|c|c|c|c|c|c|c|c|c|c|}
\hline & $\begin{array}{l}\text { Pre-primary } \\
\text { expansion }\end{array}$ & $\begin{array}{l}\text { Pre-primary } \\
\text { teacher } \\
\text { qualification }\end{array}$ & $\begin{array}{l}\text { Duration } \\
\text { compulsory } \\
\text { school }\end{array}$ & $\begin{array}{l}\text { Beginning } \\
\text { age comp } \\
\text { education }\end{array}$ & $\begin{array}{l}\text { Leaving age } \\
\text { comp } \\
\text { education }\end{array}$ & $\begin{array}{c}\text { Primary } \\
\text { teacher } \\
\text { qualification }\end{array}$ & $\begin{array}{l}\text { Secondary } \\
\text { teacher } \\
\text { qualification }\end{array}$ & Tracking age & $\begin{array}{l}\text { Standardised } \\
\text { tests (for } \\
\text { career adv.) }\end{array}$ & $\begin{array}{l}\text { Standardised } \\
\text { tests (for other } \\
\text { purposes) }\end{array}$ \\
\hline & (1) & (2) & (3) & (4) & (5) & (6) & $(7)$ & (8) & (9) & (10) \\
\hline \multirow[t]{2}{*}{ Graduate parent } & $3.454^{\star \star \star}$ & $3.454^{\star \star \star}$ & $3.454^{\star \star \star}$ & $3.454^{\star \star \star}$ & $3.454^{\star \star \star}$ & $3.454^{\star x \star}$ & $3.454^{\star \star \star}$ & $3.454^{\star \star \star}$ & $3.454^{\star \star \star}$ & $3.454^{\star \star \star}$ \\
\hline & [0.039] & [0.039] & [0.039] & [0.039] & [0.039] & [0.039] & [0.039] & [0.039] & [0.039] & [0.039] \\
\hline \multirow[t]{2}{*}{ Reform } & $0.083^{\star \star}$ & 0.054 & -0.013 & 0.011 & -0.015 & -0.045 & 0.041 & $0.014^{\star \star}$ & -0.087 & $-0.119^{\star \star \star}$ \\
\hline & [0.034] & [0.036] & [0.010] & [0.063] & [0.010] & [0.035] & [0.033] & [0.007] & [0.061] & [0.058] \\
\hline Obs. & 312269 & 312269 & 312269 & 312269 & 312269 & 312269 & 312269 & 312269 & 312269 & 312269 \\
\hline$R^{2}$ & 0.189 & 0.189 & 0.189 & 0.189 & 0.189 & 0.189 & 0.189 & 0.189 & 0.189 & 0.189 \\
\hline \multirow[t]{3}{*}{ Countries } & 24 & 24 & 24 & 24 & 24 & 24 & 24 & 24 & 24 & 24 \\
\hline & $\begin{array}{c}\text { School } \\
\text { evaluation }\end{array}$ & $\begin{array}{l}\text { School } \\
\text { autonomy }\end{array}$ & $\begin{array}{l}\text { Teacher } \\
\text { autonomy }\end{array}$ & $\begin{array}{c}\text { Selectivity } \\
\text { university } \\
\text { access }\end{array}$ & $\begin{array}{c}\text { Expansion } \\
\text { university } \\
\text { access } \\
\end{array}$ & $\begin{array}{l}\text { Increase } \\
\text { grant size }\end{array}$ & $\begin{array}{l}\text { Loan to grant } \\
\text { component }\end{array}$ & Interest rate & $\begin{array}{c}\text { Index of } \\
\text { university } \\
\text { autonomy }\end{array}$ & \\
\hline & (11) & $(12)$ & (13) & (14) & (15) & (16) & $(17)$ & (18) & (19) & \\
\hline \multirow[t]{2}{*}{ Graduate parent } & $3.454^{\star \star \star *}$ & $3.454^{\star \star \star *}$ & $3.454^{\star \star \star}$ & $3.515^{\star \star * *}$ & $3.454^{\star \star \star *}$ & $3.516^{\star \star \star}$ & $3.515^{\star \star \star *}$ & $3.515^{\star x *}$ & $3.491^{\star \star \star ~}$ & \\
\hline & [0.039] & [0.039] & [0.039] & [0.051] & [0.039] & [0.051] & [0.051] & [0.051] & [0.048] & \\
\hline \multirow[t]{2}{*}{ Reform } & 0.022 & $-0.092^{\star}$ & -0.072 & -0.004 & $-0.054^{\star}$ & $0.209^{\star \star}$ & 0.153 & 0.175 & -0.043 & \\
\hline & [0.071] & [0.053] & [0.045] & [0.049] & [0.030] & [0.085] & [0.116] & [0.158] & [0.068] & \\
\hline Obs. & 312269 & 312269 & 312269 & 213469 & 312269 & 213469 & 213469 & 213469 & 228316 & \\
\hline $\mathrm{R}^{2}$ & 0.189 & 0.189 & 0.189 & 0.212 & 0.189 & 0.212 & 0.212 & 0.212 & 0.208 & \\
\hline Countries & 24 & 24 & 24 & $17^{\#}$ & 24 & $17^{\#}$ & $17^{\#}$ & $17^{\#}$ & $18^{\# \#}$ & \\
\hline
\end{tabular}


Table B5: Reforms impact with randomly generated country of birth

\begin{tabular}{|c|c|c|c|c|c|c|c|c|c|c|}
\hline & $\begin{array}{l}\text { Preprimary } \\
\text { expansion }\end{array}$ & $\begin{array}{c}\text { Pre-primary } \\
\text { teacher } \\
\text { qualification }\end{array}$ & $\begin{array}{c}\text { Duration } \\
\text { compulsory } \\
\text { school } \\
\end{array}$ & $\begin{array}{l}\text { Beginning } \\
\text { age comp } \\
\text { education }\end{array}$ & $\begin{array}{l}\text { Leaving age } \\
\text { comp } \\
\text { education }\end{array}$ & $\begin{array}{c}\text { Primary } \\
\text { teacher } \\
\text { qualification } \\
\end{array}$ & $\begin{array}{c}\text { Secondary } \\
\text { teacher } \\
\text { qualification }\end{array}$ & Tracking age & $\begin{array}{l}\text { Standardised } \\
\text { tests (for } \\
\text { career adv.) }\end{array}$ & $\begin{array}{c}\text { Standardised } \\
\text { tests (for other } \\
\text { purposes) }\end{array}$ \\
\hline & (1) & (2) & (3) & (4) & (5) & (6) & (7) & (8) & (9) & (10) \\
\hline Graduate parent & $\begin{array}{c}3.482^{\star \star \star} \\
{[0.029]}\end{array}$ & $\begin{array}{c}3.482^{\star \star \star} \\
{[0.029]}\end{array}$ & $\begin{array}{c}3.482^{\star \star \star} \\
{[0.029]}\end{array}$ & $\begin{array}{c}3.482^{\star \star \star} \\
{[0.029]}\end{array}$ & $\begin{array}{c}3.482^{\star \star \star} \\
{[0.029]}\end{array}$ & $\begin{array}{c}3.482^{\star \star \star} \\
{[0.029]}\end{array}$ & $\begin{array}{c}3.482^{\star k \star} \\
{[0.029]}\end{array}$ & $\begin{array}{c}3.482^{\star \star \star} \\
{[0.029]}\end{array}$ & $\begin{array}{c}3.482^{\star \star \star} \\
{[0.029]}\end{array}$ & $\begin{array}{c}3.482^{\star \star \star} \\
{[0.029]}\end{array}$ \\
\hline Reform & $\begin{array}{c}0.006 \\
{[0.040]}\end{array}$ & $\begin{array}{c}-0.096 \text { * } \\
{[0.038]}\end{array}$ & $\begin{array}{l}-0.023^{\star \star} \\
{[0.010]}\end{array}$ & $\begin{array}{l}-0.046 \\
{[0.072]}\end{array}$ & $\begin{array}{l}-0.022^{\star *} \\
{[0.011]}\end{array}$ & $\begin{array}{l}-0.079^{\star} \\
{[0.041]}\end{array}$ & $\begin{array}{l}-0.019 \\
{[0.037]}\end{array}$ & $\begin{array}{l}-0.007 \\
{[0.007]}\end{array}$ & $\begin{array}{c}0.156^{\star \star *} \\
{[0.056]}\end{array}$ & $\begin{array}{l}-0.042 \\
{[0.065]}\end{array}$ \\
\hline $\begin{array}{l}\text { Obs. } \\
R^{2}\end{array}$ & $\begin{array}{c}323284 \\
0.159\end{array}$ & $\begin{array}{c}323284 \\
0.159\end{array}$ & $\begin{array}{c}323284 \\
0.159\end{array}$ & $\begin{array}{c}323284 \\
0.159\end{array}$ & $\begin{array}{c}323284 \\
0.159\end{array}$ & $\begin{array}{c}323284 \\
0.159\end{array}$ & $\begin{array}{c}323284 \\
0.159\end{array}$ & $\begin{array}{c}323284 \\
0.159\end{array}$ & $\begin{array}{c}323284 \\
0.159\end{array}$ & $\begin{array}{c}323284 \\
0.159\end{array}$ \\
\hline \multirow[t]{3}{*}{ Countries } & 24 & 24 & 24 & 24 & 24 & 24 & 24 & 24 & 24 & 24 \\
\hline & $\begin{array}{c}\text { School } \\
\text { evaluation }\end{array}$ & $\begin{array}{l}\text { School } \\
\text { autonomy }\end{array}$ & $\begin{array}{l}\text { Teacher } \\
\text { autonomy }\end{array}$ & $\begin{array}{c}\text { Selectivity } \\
\text { university } \\
\text { access }\end{array}$ & $\begin{array}{c}\text { Expansion } \\
\text { university } \\
\text { access }\end{array}$ & $\begin{array}{l}\text { Increase } \\
\text { grant size }\end{array}$ & $\begin{array}{l}\text { Loan to grant } \\
\text { component }\end{array}$ & Interest rate & $\begin{array}{l}\text { Index of } \\
\text { university } \\
\text { autonomy }\end{array}$ & \\
\hline & (11) & (12) & (13) & (14) & (15) & (16) & (17) & (18) & (19) & \\
\hline Graduate parent & $\begin{array}{c}3.482^{\star \star \star} \\
{[0.029]}\end{array}$ & $\begin{array}{c}3.482^{\star \star \star} \\
{[0.029]}\end{array}$ & $\begin{array}{c}3.482^{\star \star \star} \\
{[0.029]}\end{array}$ & $\begin{array}{c}3.477^{\star \star \star} \\
{[0.034]}\end{array}$ & $\begin{array}{c}3.482^{\star \star \star} \\
{[0.029]}\end{array}$ & $\begin{array}{c}3.477^{\star \star *} \\
{[0.034]}\end{array}$ & $\begin{array}{c}3.477^{\star \star \star} \\
{[0.034]}\end{array}$ & $\begin{array}{c}3.477^{\star \star} \\
{[0.034]}\end{array}$ & $\begin{array}{c}3.462^{\star \star \star} \\
{[0.033]}\end{array}$ & \\
\hline Reform & $\begin{array}{l}-0.055 \\
{[0.072]}\end{array}$ & $\begin{array}{c}-0.156^{\star \star} \\
{[0.073]}\end{array}$ & $\begin{array}{l}-0.038 \\
{[0.058]}\end{array}$ & $\begin{array}{c}0.061 \\
{[0.051]}\end{array}$ & $\begin{array}{l}0.073^{\star \star} \\
{[0.036]}\end{array}$ & $\begin{array}{l}-0.047 \\
{[0.090]}\end{array}$ & $\begin{array}{c}0.098 \\
{[0.115]}\end{array}$ & $\begin{array}{l}-0.090 \\
{[0.135]}\end{array}$ & $\begin{array}{l}-0.080 \\
{[0.066]}\end{array}$ & \\
\hline Obs. & 323284 & 323284 & 323284 & 222614 & 323284 & 222614 & 222614 & 222614 & 235882 & \\
\hline $\mathrm{R}^{2}$ & 0.159 & 0.159 & 0.159 & 0.161 & 0.159 & 0.161 & 0.161 & 0.161 & 0.160 & \\
\hline Countries & 24 & 24 & 24 & $17^{\#}$ & 24 & $17^{\#}$ & $17^{\#}$ & $17^{\#}$ & $18^{\# \#}$ & \\
\hline
\end{tabular}

Note: standard errors clustered by country $\times$ age cohorts in brackets - statistical significance: $* * * p<0.01, * * p<0.05, * p<0.1-$

Constant, gender, birth year, country, survey controls and country specific time trend included

- \#: no reform data for Estonia, Hungary, Latvia, Poland, Slovak Rp., Slovenia and Czech Rp.;

\#\# : no reform data for Estonia, Hungary, Latvia, Poland, Slovak Rp. and Slovenia 
Table B6: Factor analysis - principle component method - two groups

\begin{tabular}{|c|c|c|c|c|c|c|}
\hline & Factors & Eigenvalue & $\begin{array}{c}\text { Cumulative } \\
\text { variance } \\
\text { explained } \\
\end{array}$ & Name of original variable & Factor loading & $\begin{array}{l}\text { countries } \\
\text { available }\end{array}$ \\
\hline \multirow[t]{10}{*}{ Inclusive } & 1 & 3.601 & 0.360 & Duration compulsory school & 0.837 & \multirow{25}{*}{$\begin{array}{c}17 \text { (no Estonia, } \\
\text { Hungary, Latvia, } \\
\text { Poland, Slovak } \\
\text { Rp., Slovenia } \\
\text { and Czech Rp.) }\end{array}$} \\
\hline & 2 & 1.952 & 0.555 & Beginning age of comp. education & -0.234 & \\
\hline & 3 & 1.168 & 0.672 & Leaving age of comp. education & 0.874 & \\
\hline & 4 & 0.970 & 0.769 & Pre-primary expansion & 0.720 & \\
\hline & 5 & 0.834 & 0.853 & Tracking age & 0.572 & \\
\hline & 6 & 0.517 & 0.904 & Expansion of university access & 0.820 & \\
\hline & 7 & 0.466 & 0.951 & Selectivity university access & 0.541 & \\
\hline & 8 & 0.252 & 0.976 & Increase grant size & 0.299 & \\
\hline & 9 & 0.238 & 1.000 & Loan to grant component & 0.372 & \\
\hline & 10 & 0.000 & 1.000 & Interest rate & 0.210 & \\
\hline \multirow[t]{15}{*}{ Selective } & 1 & 7.637 & 0.509 & Standardised tests (for career adv) & 7.637 & \\
\hline & 2 & 1.628 & 0.618 & Standardised tests (for other purp) & 1.628 & \\
\hline & 3 & 1.330 & 0.706 & School evaluation & 1.330 & \\
\hline & 4 & 0.854 & 0.763 & School autonomy & 0.854 & \\
\hline & 5 & 0.671 & 0.808 & Teacher autonomy & 0.671 & \\
\hline & 6 & 0.561 & 0.845 & Pre-primary teacher qualification & 0.561 & \\
\hline & 7 & 0.484 & 0.878 & Primary teacher qualification & 0.484 & \\
\hline & 8 & 0.388 & 0.904 & Secondary teacher qualification & 0.388 & \\
\hline & 9 & 0.341 & 0.926 & Budget autonomy & 0.341 & \\
\hline & 10 & 0.296 & 0.946 & Recruitment autonomy & 0.296 & \\
\hline & 11 & 0.229 & 0.961 & Organization autonomy & 0.229 & \\
\hline & 12 & 0.199 & 0.974 & Logistic autonomy & 0.199 & \\
\hline & 13 & 0.177 & 0.986 & Course autonomy & 0.177 & \\
\hline & 14 & 0.123 & 0.995 & Self-evaluation & 0.123 & \\
\hline & 15 & 0.083 & 1.000 & Development plan autonomy & 0.083 & \\
\hline
\end{tabular}


Table B7: Mean values of reform factors by countries

\begin{tabular}{lccccccc}
\hline & Compulsory & Comprehensive & $\begin{array}{c}\text { University } \\
\text { support 1 }\end{array}$ & $\begin{array}{c}\text { University } \\
\text { support 2 }\end{array}$ & Accountability & $\begin{array}{c}\text { Teacher } \\
\text { qualification }\end{array}$ & $\begin{array}{c}\text { University } \\
\text { autonomy }\end{array}$ \\
\hline \hline & & & & & & & \\
Austria & 0.23 & -0.77 & -1.16 & 0.16 & 0.19 & -0.14 & -0.46 \\
Belgium FL & 0.44 & 0.27 & -1.26 & -0.14 & 0.37 & 0.25 & -0.32 \\
Belgium FR & 0.44 & 0.82 & 0.44 & -1.30 & 0.51 & -0.04 & -0.08 \\
Czech republic & 0.37 & 0.21 & na & na & -0.21 & 0.97 & -0.33 \\
Denmark & -0.85 & 0.30 & 0.88 & -0.31 & 0.00 & 0.16 & -0.06 \\
Estonia & -0.27 & 0.65 & na & na & -0.20 & -0.28 & na \\
Finland & -0.53 & 0.00 & 1.49 & 0.25 & -0.42 & -0.47 & 0.11 \\
France & 0.38 & -0.52 & -0.31 & -0.55 & 0.14 & -0.33 & -0.20 \\
Germany & 0.16 & -0.40 & 0.71 & -0.75 & -0.60 & 0.47 & 0.04 \\
Great Britain & 1.14 & -0.15 & 0.19 & 1.01 & 0.56 & -0.30 & 0.57 \\
Greece & -0.56 & -0.11 & -1.00 & 0.48 & -0.53 & 0.10 & -0.05 \\
Hungary & 0.70 & -0.54 & na & na & -0.08 & -0.38 & na \\
Ireland & 0.16 & -0.48 & -0.81 & 0.97 & -0.17 & 0.05 & 0.57 \\
Italy & -0.80 & 0.10 & -0.37 & -0.73 & -0.45 & -0.44 & -0.30 \\
Latvia & -0.30 & 0.39 & na & na & -0.25 & 0.36 & na \\
Netherlands & 0.39 & -0.38 & 0.53 & -0.74 & 1.15 & -0.55 & -0.03 \\
Northern Ireland & 0.66 & -0.69 & 0.35 & 1.35 & 1.20 & -0.32 & 0.57 \\
Norway & -0.14 & 0.41 & 1.45 & 0.09 & -0.44 & -0.12 & -0.11 \\
Poland & 0.30 & 0.74 & na & na & -0.35 & 0.67 & na \\
Portugal & -1.57 & -0.27 & -0.96 & 0.64 & 0.11 & -0.56 & -0.26 \\
Slovak Republic & 0.43 & 0.37 & na & na & -0.32 & 0.65 & na \\
Slovenia & -0.10 & 0.40 & na & na & -0.27 & 0.04 & na \\
Spain & -0.49 & -0.50 & -1.05 & 0.36 & -0.08 & -0.02 & 0.06 \\
Sweden & -0.21 & 0.15 & 0.90 & -0.80 & 0.16 & 0.22 & 0.28 \\
\hline
\end{tabular}


Table B8: Educational reform and policy variables - alternative specifications - 1945-2000

\begin{tabular}{|c|c|c|c|c|c|c|c|c|c|}
\hline & 1 & 2 & 3 & 4 & 5 & 6 & 7 & 8 & 9 \\
\hline & compulsory & comprehensive & support1 & support2 & inclusive & accountability & teacher & uniautonomy & selective \\
\hline right-wing orientation of the & 0.063 & -0.116 & -0.089 & 0.133 & -0.036 & 0.041 & -0.052 & 0.007 & -0.003 \\
\hline government & {$[4.49]^{\star \star \star}$} & {$[9.29]^{\star \star \star}$} & {$[4.06]^{\star \star \star}$} & {$[6.35]^{\star \star \star}$} & {$[3.72]^{\star \star \star}$} & {$[2.06]^{\star \star}$} & {$[4.71]^{\star \star \star}$} & {$[0.46]$} & {$[0.25]$} \\
\hline Observations & 928 & 928 & 852 & 852 & 852 & 928 & 928 & 863 & 863 \\
\hline \multirow[t]{2}{*}{$\mathrm{R}^{2}$} & 0.54 & 0.692 & 0.197 & 0.42 & 0.768 & 0.529 & 0.741 & 0.641 & 0.73 \\
\hline & compulsory & comprehensive & support1 & support2 & inclusive & accountability & teacher & uniautonomy & selective \\
\hline right-wing orientation of the & 0.066 & -0.118 & -0.089 & 0.133 & -0.036 & 0.043 & -0.053 & 0.007 & -0.003 \\
\hline cabinet & {$[4.70]^{\star \star \star}$} & {$[9.53]^{\star \star \star}$} & {$[4.35]^{\star \star \star}$} & {$[6.39]^{\star \star \star}$} & {$[3.85]^{\star \star *}$} & {$[2.13]^{\star \star}$} & {$[4.86]^{\star \star *}$} & [0.48] & {$[0.24]$} \\
\hline cabinet support in the & 0.902 & -0.939 & -2.4 & -0.326 & -0.68 & 0.884 & -0.507 & -0.82 & -0.527 \\
\hline$\overline{\text { parliament }}$ & {$[5.60]^{\star \star \star}$} & {$[5.89]^{\star \star \star}$} & {$[9.22]^{\star \star \star}$} & [1.63] & {$[5.45]^{\star \star \star}$} & {$[4.52]^{\star \star \star}$} & {$[3.78]^{\star \star \star}$} & {$[5.25]^{\star \star \star}$} & {$[3.96]^{\star \star \star}$} \\
\hline Observations & 928 & 928 & 852 & 852 & 852 & 928 & 928 & 863 & 863 \\
\hline \multirow[t]{2}{*}{ R-squared } & 0.553 & 0.704 & 0.279 & 0.421 & 0.776 & 0.537 & 0.744 & 0.648 & 0.733 \\
\hline & compulsory & comprehensive & support1 & support2 & inclusive & accountability & teacher & uniautonomy & selective \\
\hline right-wing orientation of the & 0.142 & -0.38 & -0.123 & 0.83 & -0.111 & 0.191 & -0.017 & 0.344 & 0.268 \\
\hline parliament & {$[4.89]^{\star \star \star}$} & {$[9.35]^{\star \star *}$} & {$[2.38]^{\star \star}$} & {$[12.50]^{\star \star \star}$} & {$[4.44]^{\star \star \star}$} & {$[4.86]^{\star \star \star}$} & [0.62] & {$[7.44]^{\star \star \star}$} & {$[6.61]^{\star \star \star}$} \\
\hline Observations & 928 & 928 & 852 & 852 & 852 & 928 & 928 & 863 & 863 \\
\hline \multirow[t]{2}{*}{$\mathrm{R}^{2}$} & 0.54 & 0.724 & 0.187 & 0.562 & 0.769 & 0.537 & 0.735 & 0.669 & 0.748 \\
\hline & compulsory & comprehensive & support1 & support2 & inclusive & accountability & teacher & uniautonomy & selective \\
\hline political complexion of & 0.017 & -0.053 & -0.062 & 0.076 & -0.025 & 0.013 & -0.019 & 0.007 & 0.004 \\
\hline parliament and government & [1.30] & {$[4.72]^{\star \star \star}$} & {$[3.85]^{\star \star \star}$} & {$[4.49]^{\star \star \star}$} & {$[3.14]^{\star \star \star}$} & {$[0.80]$} & {$[1.99]^{\star *}$} & {$[0.56]$} & {$[0.34]$} \\
\hline Observations & 940 & 940 & 873 & 873 & 873 & 940 & 940 & 884 & 884 \\
\hline $\mathrm{R}^{2}$ & 0.533 & 0.68 & 0.163 & 0.404 & 0.767 & 0.534 & 0.734 & 0.651 & 0.738 \\
\hline
\end{tabular}

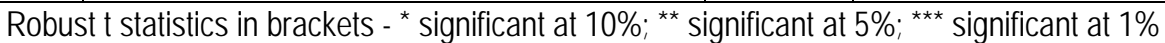
constant and country-specific time trend included 